\title{
Radical Spaces: \\ New Zealand's Resistance Bookshops, 1969-1977
}

\author{
Megan Simpson
}

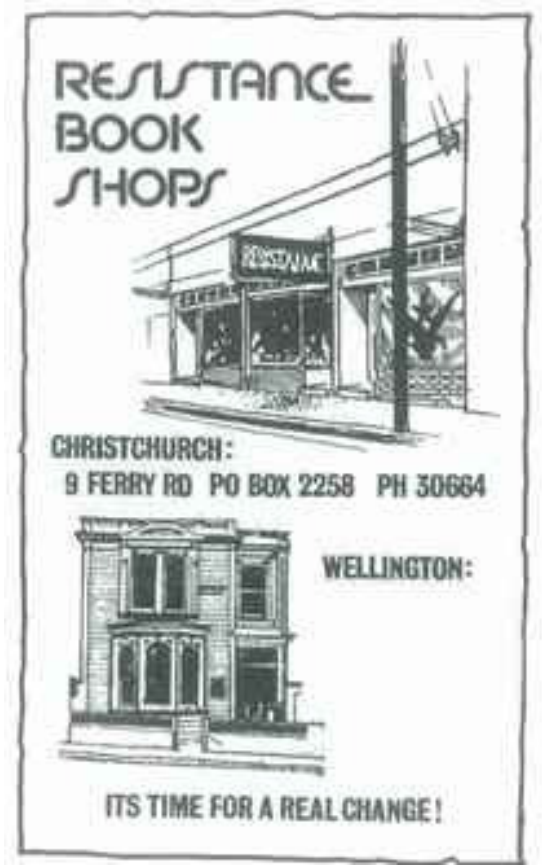

A Thesis Submitted to the Victoria University of Wellington in Fulfilment of the Requirement for the Degree of Masters of Arts in History 


\section{Table of Contents}

\section{Page}

Illustrations

iii

Abbreviations

V

Acknowledgements

vi

Abstract

vii

Introduction

1

Chapter One Print, Protest and Politics: The Resistance Bookshops and 17 the wider culture of protest in New Zealand 1969-1977

Chapter Two

From the "bowels of the underground": An overview of the Resistance Bookshops

44

Chapter Three

Challenging Conventions: The Resistance Bookshops and 97 the role of print in radical politics

Conclusion

Bibliography 


\section{Illustrations}

Figure

Page

1 Joint advertisement for the Wellington and Christchurch Resistance Bookshops, Cover The Southern Flyer, Issue 23, February 1976, p.3

2 Cover of The Muldoon Annual Jokebook, 1971

3 Sensationalist coverage of radical politics in the $8 o^{\prime}$ 'clock Auckland Star, $1972 \quad 28$

4 Leaflet produced by the Campaign Against Foreign Control in New Zealand, 30 1975

$5 \quad$ Women's National Abortion Action Campaign (WONAAC) Newsletter, 1975

6 Photograph of the People's Union in Ponsonby, Auckland, 1979

$7 \quad$ Earwig headline concerning Dennis Cooney and the Resistance Bookshop in 41 Auckland, 1972

8 The revolutionary and the printing press, an illustration printed by Kozmik 48 Krumbia, c.1973

$9 \quad$ Auckland, Wellington and Christchurch Resistance Bookshop logos, 1969-77 53

10 Advertisement for the three bookshops placed in the New Zealand Listener, 54 1973

11 Advertisement for the Auckland Resistance Bookshop, 1972

12 Photographs of buyers for the Resistance Food Cooperative in Auckland, 59 c. 1972

13 Auckland Resistance Bookshop shop window, c.1972 62

14 Photograph of the Resistance Bookshop in Wellington damaged by fire, $1970 \quad 68$

15 Shareholder certificates for the Wellington Resistance Bookshop, 1971

16 Advertisement for the Wellington Resistance Bookshop, undated 71

17 The controversial cover of Itch magazine, 1972

18 Photograph of the interior of the Resistance Bookshops at 144 Willis Street, 78 Wellington, c. 1975

19 Photo of the exterior of the Christchurch Resistance Bookshop, 1973 
20 Advertisement for the Resistance Bookshop in Christchurch, undated

21 Advertisement for the Resistance Bookshop in Christchurch, 1975

22 Inside Kozmik Krumbia, the printery at the Resistance Bookshop in Christchurch, 1973

23 Marty Braithwaite watching Kozmik Krumbia being searched by police, 1973

24 Political groups' publications from 1976

25 Underground magazine covers produced c.1971-1973 102

26 'The Pornshop Strangler Strikes Again!', headline from Cock, 1971

27 Unconventional page layout of Earwig, c.1972 104

28 A selection of book covers produced by Alister Taylor Publications in the early 1970s

29 Cover of XYZ Comics, 1972

$30 \quad$ Nude female images included in Cock between 1969-1971 


\begin{tabular}{|c|c|}
\hline \multicolumn{2}{|r|}{ Abbreviations } \\
\hline AGM & Annual General Meeting \\
\hline ATL & Alexander Turnbull Library \\
\hline AUSAPOCPAH & $\begin{array}{l}\text { Auckland University Society for the Active Prevention of } \\
\text { Cruelty to Politically Apathetic Humans }\end{array}$ \\
\hline CAFCA & Campaign Against Foreign Control of Aotearoa \\
\hline CAFCNZ & Campaign Against Foreign Control of New Zealand \\
\hline CAFMANZ & Campaign Against Foreign Military Activities in New Zealand \\
\hline CARE & Citizens Association for Racial Equality \\
\hline CCFP & Counter Culture Free Press \\
\hline CND & Campaign for Nuclear Disarmament \\
\hline CPNZ & Communist Party of New Zealand \\
\hline $\mathrm{CoV}$ & Committee on Vietnam \\
\hline CPNZ & New Zealand Communist Party \\
\hline GLF & Gay Liberation Front \\
\hline HART & Halt All Racist Tours \\
\hline IRD & Inland Revenue Department \\
\hline IPT & Indecent Publications Tribunal \\
\hline LBC & Left Book Club \\
\hline MBL & MacMillan Brown Library, University of Canterbury \\
\hline MOOHR & Maori Organisation on Human Rights \\
\hline NORML & National Organisation for the Reform of Marijuana Laws \\
\hline NZBC & New Zealand Broadcasting Company \\
\hline NZUSA & New Zealand University Students Association \\
\hline$N Z W E C$ & New Zealand Whole Earth Catalogue \\
\hline OHMS & Organisation to Halt Military Service \\
\hline PFVC & Peace for Vietnam Committee \\
\hline PPP & Polynesian Panther Party \\
\hline PU & People's Union \\
\hline PYM & Progressive Youth Movement \\
\hline RAVPOC & Release All Vietnamese Prisoners of Conscience \\
\hline REC & Radical Election Campaign \\
\hline SAL & Socialist Action League \\
\hline SDS & Students for a Democratic Society \\
\hline SHE & Sisters for Homophile Equality \\
\hline SUP & Socialist Unity Party \\
\hline TFML & Tom Fanthorpe Memorial Library \\
\hline TPA & Tenants Protection Association \\
\hline UPS & Underground Press Syndicate \\
\hline WONAAC & Women's National Abortion Action Campaign \\
\hline Yippies & Youth International Party \\
\hline
\end{tabular}




\section{Acknowledgements}

This project was made possible first and foremost through the participation of Sue Bradford, Marty Braithwaite, Tony Currie, Murray Horton, Bill Rosenberg and Richard Suggate. I was given the opportunity to interview each of these individuals about their experiences with the Resistance Bookshops and I am very thankful for their contribution to my research.

I am indebted to my supervisors Charlotte Macdonald and Malcolm McKinnon, whose advice and support guided me throughout the course of this study. Thank you to Siobhan Simpson and Rebecca Lenihan for their encouragement and comments on my draft. And to my family and friends who always listened with a supportive ear. 


\begin{abstract}
'Radical Spaces' explores the Resistance Bookshops and their place within the culture of protest and radical politics in New Zealand between 1969 and 1977. The bookshops, which were set up by activists in Auckland, Wellington and Christchurch aimed to raise consciousness about political issues by selling political and countercultural texts which had limited availability in New Zealand. These 'radical spaces' of the 1970s are closely examined, looking at specific political campaigns, the interconnections between the groups and individuals involved, and the role that the Resistance Bookshops played in supporting the radical political momentum that flourished in New Zealand from the late 1960s until the mid-1970s. For the Resistance Bookshops, distributing texts was part of the political process, it was recognised that there was power in ideas and print was a leading medium for which to circulate them. This thesis examines the role of print as a key part in political mobilisation. All radical political groups whether 'Old Left', 'New Left', feminist or anarchist used print to educate, communicate and persuade people to participate in street politics and the wider radical culture that was emerging in New Zealand during this period. The Resistance Bookshops provided a bridge between political groups and the printed material that helped shape the ideas behind individual campaigns. These spaces were instrumental in the dissemination of radical ideas and are important expressions of a 'movement' which placed prime importance on education as a political tool.
\end{abstract}




\section{Introduction}

"At last you have the opportunity to get together and cooperate to build a strong movement in Christchurch" declared Ferret in April 1973. ${ }^{1}$ In its inaugural issue, the magazine welcomed the opening of the Resistance Bookshop and Action Centre. The new shop and action centre was a space established to sell and produce political material, where its founders would endeavour to create a base for organising ongoing political activity in the city. This was the third Resistance Bookshop to be opened in New Zealand, following the first in Auckland in 1969 and second in Wellington in 1970. The three bookshops, while independent of each other, all shared the common goal of selling political books and magazines that were generally not stocked by other booksellers. By supplying political and alternative literature, the bookshops were aimed to 'raise consciousness' and encourage people to mobilise for political causes. The Resistance Bookshops pushed people to question, confront and participate in activities which challenged 'conventional' social and political orthodoxies. Most importantly, through consciousness-raising, the bookshops aimed to encourage people to reject apathy for political action.

All three Resistance Bookshops embraced the notion of 'Radical Spaces', a place where left wing, extreme or revolutionary views are held or advocated. From the proabortion, anti-war window displays through to the Marxist study groups, the Resistance Bookshops continually promoted radical, political causes during the 1970s. The shops opened during a period of conspicuous change, when predominantly young people with an anti-authoritarian outlook began to question the 'Establishment' in all its forms. ${ }^{2}$ The bookshops were an extension of this radical questioning. They stocked and sold publications that were left wing in their perspective and often advocated widespread social change through a radical over-throw of societal conventions. As well as presenting such radical positions through the publications stocked, the individuals involved also conveyed this stance through their association with, and participation in, politically active groups and campaigns. However, the title 'Radical Spaces' represented more than just the physical location and activities of the

\footnotetext{
1 'Resistance', Ferret, Issue 2, February 1973, p.19.

2 The term 'Establishment' was used generally by activists to represent authoritative structures like the government, armed forces, institutions, parents and school principals.
} 
bookshops. Rather, the bookshops were part of a political momentum which flourished during the early 1970s and symbolically this momentum can also be considered as a 'Radical Space'.

The terms 'radical', 'revolutionary' and 'extreme' are all used in this thesis. Such broad and non-binding terminology is used because of the difficulty of clearly defining the particular political positions of those involved with the bookshops. No one political ideology was adopted by any of the bookshops, as they aimed to be nonsectarian. As a result of this position, the shops' advertising and correspondence tended to also use words like 'radical' and 'revolutionary', which were indicative of their aspirations for widespread social and political change. The term 'extreme' however, was not self-imposed; rather it reflected the view of those outside the movement. To some, the views held by those involved with the Resistance Bookshops and radical politics generally, would have been 'extreme' in the sense that they were far removed from mainstream political positions. The radical politics advocated by the Resistance Bookshops and the associated political movements went beyond traditional left wing ideology. The range of social and political movements which were active during the 1970 s meant that there were multiple political ideologies coexisting under the banner of 'radical politics'. For movements like the alternative lifestyle movement or for the environmental campaigns, there was generally no political ideology which united people; instead individuals were drawn to participate more out of an ethical or social conviction rather an allegiance to a single political ideology.

As booksellers, the Resistance Bookshops can be defined in various ways, as: 'underground' bookshops, 'cooperative' bookshops, 'leftist' bookshops but perhaps the most appropriate description is that of 'alternative' bookshops. ${ }^{3}$ The term 'alternative' suggests that the type of material that is stocked differs from that of mainstream or chain-type bookshops but it also has connotations to the 'alternative' movement more generally. It suggests that a substitute option is being proposed, and in the case of these bookshops, while criticising aspects of society they were also putting forward alternatives for the future. Whether this was through the lifestyle

\footnotetext{
${ }^{3}$ The term 'underground' suggests that something is clandestine or illicit, however, it is also often used to describe something that is non-mainstream or even avant-garde.
} 
changes promoted in the do-it-yourself alternative lifestyle texts, such as the $\mathrm{New}$ Zealand Whole Earth Catalogue (NZWEC) or through anarchist philosophy, the stock sold by the bookshops suggested alternatives to those readers who sought them. ${ }^{4}$

While the Resistance Bookshops endeavoured to sell political and countercultural material, this was not the first time that political groups had established bookshops to sell political material in New Zealand. ${ }^{5}$ Left-wing cooperative booksellers emerged in the 1930s, led by cooperative book societies, who were regionally organised groups, often associated with the Communist Party of New Zealand (CPNZ). The cooperative book societies set up bookshops in the four main cities with the first opening in Auckland in 1936. ${ }^{6}$ All four stocked left wing material, much of which was sourced from the Left Book Club (LBC) in England, which distributed and often commissioned leftist works. ${ }^{7}$ The LBC played a key role in enabling left wing material to be published and distributed widely, contributing to building a leftist print culture worldwide.

There are a number of similarities and differences between the early cooperatives and the Resistance Bookshops. Firstly, the Resistance Bookshops were more overtly politically active than the earlier left-wing booksellers. This was evident by their choice of name. The bookshops established in the 1930s and 1940s were named 'Progressive', 'Modern' and 'Co-op' bookshops, all terms which do not have the active and confrontational connotations of the term 'Resistance'. Secondly, the cooperatives generally had a single purpose which was to sell a wide range of liberal and leftist material. Resistance also existed for the same reason but the bookshops had wider functions. The Resistance Bookshops were more than just booksellers and

\footnotetext{
${ }^{4}$ The First New Zealand Whole Earth Catalogue (NZWEC), edited by Owen Wilkes, Jim Chapple, Dennis List, Tim Shadbolt, Alan Admore and John Pettigrew,Wellington, 1972.

${ }^{5}$ The left cooperative bookselling movement in New Zealand has been extensively traced by Rachel Barrowman in A Popular Vision: the Arts and the Left in New Zealand, 1930-1950, Wellington, 1991. Also see Anna Rogers and Max Rogers, Turning the Pages: The Story of Bookselling in New Zealand, Auckland 1993.

${ }^{6}$ Auckland Progressive Bookshop (1936-1980); Christchurch Progressive Bookshop (1937-1988); Wellington Modern Books (1939-1970); Dunedin Modern Books (1943-1954).

${ }^{7}$ The LBC was established by socialist publisher Victor Gollancz in 1936, with the aim of selling radical books cheaply in an attempt to "help in the struggle for world peace and a better social and economic order, and against fascism". The book club grew rapidly and by 1939 it had over 40,000 members worldwide, a figure that was undoubtedly influenced by the advent of the Spanish Civil War, which produced a wave of international solidarity among leftist and humanist supporters of the Spanish Republican cause. Paul Laity (ed), Left Book Club Anthology, London, 2001, p.iii.
} 
distributors of leftist and alternative information. Rather, the bookshops aimed to be centres of radical activity, which meant that when they could, they provided other facilities. These included meeting space to be used by groups for organising, a cheap printing service, a food cooperative, some shops had accommodation available, and all three acted as coordinating points for communicating about upcoming demonstrations. Some shops also held public meetings with speakers who addressed a range of political topics from Marxism to lesbianism to trade unionism in New Zealand. Aside from functional differences, the early cooperatives and the three Resistance Bookshops were linked through issues associated with book importing and censorship. The Customs Department often seized imported books that were regarded as having explicit sexual content. The importing of Nabokov's Lolita was a high profile issue for the cooperative bookshops in the 1950s. ${ }^{8}$ The difficulties associated with importing texts that confronted sexual taboos was an issue that the Resistance Bookshops also faced. The shops imported American underground comics, which were often sexually explicit and violent. The texts were different in nature but the fundamental issue was the same. Texts that were sexually explicit, not political, were seized by Customs and after their assessment by the Indecent Publications Tribunal (IPT), they were often banned from sale. ${ }^{9}$

While all three Resistance Bookshops shared a name and during the course of the 1970s many of the individuals involved spent time working in more than one shop, they were not a franchise and were run independently of each other. Each shop was run by a collective, which comprised a group of mostly young unpaid politically committed individuals. People involved themselves at various levels, from the high level of responsibility of the shop manager through to those who worked on an occasional basis behind the counter or those who sorted the food for the food cooperative. The numerous functions that each Resistance Bookshop took on, demonstrated that their purpose was about something much larger than bookselling. As Ferret commented, it was about building a movement, which meant education, creating dialogue and cooperation between political groups and providing a space in which these activities could be carried out.

\footnotetext{
${ }^{8}$ Vladimir Nabokov, Lolita, Paris, 1955.

${ }^{9}$ For an index of the titles assessed by the Indecent Publications Tribunal (IPT) in the 1960s and 70s see Stuart Perry, Indecent Publications: Control in New Zealand, Wellington, 1980.
} 
Each bookshop was formed on principles of collectivism, a concept which focuses on a group or community rather than hierarchy and specialisation. The wider political culture of this period also embraced this concept of collective action to bring about social change and as the Resistance Bookshops were a product of this political momentum or culture, they too, embraced this reliance on the collective. For the broader protest 'movement' this ideology of collectivism was a wider critique of hierarchies generally. Collectivism was a radical concept for the three shops to adopt because bookselling is generally a commercial operation, owned by an individual or company with the goal of achieving profits through book sales. While bookselling is usually carried out by individuals who have an enthusiasm for books, the running of a shop is for profit and usually a hierarchical model is adopted, with the owner or manager directing what is sold and the day to day running of the shop. However, the Resistance Bookshops adopted what was almost the polar opposite to these practices. The collective structure of the shop relied on the more democratic idea of group decision making. Any profits (in fact there were very little) were directed back into improving the shop, which was essentially a facility to support the wider contemporary collective political action.

All three Resistance Bookshops defined themselves as non-sectarian spaces; they were committed to supporting "people of all tinges of leftist ideas". ${ }^{10}$ While nonpartisan, the Resistance Bookshops were not 'neutral' in the sense that all groups regardless of their place on the political spectrum were welcome to use the space clearly right wing political groups were not welcome. But even political parties like the Values Party were excluded from using Auckland's meeting space. This refusal to allow the Values Party access to the space arose because of the young radicals' rejection of parliamentary politics. This commitment to non-sectarianism did not mean that those involved were not individually aligned with particular left wing factions. On an individual level there were a range of opinions about things like the type of print that should be stocked or about how important it was for the bookshops to have a close relationship with the working class. These issues could be debated

\footnotetext{
${ }^{10}$ Assistance, Christchurch Resistance Bookshop and Action Centre Newsletter, 16 January 1974, Vol.2, No.1, p.1., Tom Fanthorpe Memorial Library (TFML), Box 1, Folder 3.
} 
within the collective management meetings but the fundamental intention of the bookshops' role as a non-sectarian space for political groups was not disputed.

The word 'Resistance' is itself confrontational, it implies a strong opposition to something or represents the act of non-compliance. By using the name Resistance, the bookshops were declaring that they were more than just booksellers, the term indicated strong opposition. But what was actually being 'resisted'? This varied from individual to individual, year to year and bookshop to bookshop, but there were common strands which were numerous and wide-reaching. The variety of issues consequently led to the public perception that protesters were merely just a bunch of 'antis'. Some of these issues included opposition to capitalism, imperialism, racism, sexism, war, the oppression and exploitation of workers, women, Maori and Pacific Islanders. Individuals challenged traditional attitudes to sex, drug use, spirituality, appearance, food, education, censorship, while confronting structures of societal control like the police and government. All these issues, whether requiring personal or institutional changes, or both, were defined as political. To grow one's hair was political, to reject highly processed food was political and to experiment with expanding one's consciousness through drug use could be a political statement. These acts marked a radical change in the notion of what was a political act, 'the personal was political' and individuals could resist rigid societal conventions by exploring these individual expressions as well as becoming involved in street politics.

Some of the political campaigns that these New Zealanders engaged with included the women's movement, the anti-Vietnam War movement, the anti-tour campaigns, gay liberation, environmentalism and green politics, the alternative lifestyle movement, the anti-foreign military base campaigns and Maori and Pacific Island activism. These campaigns were not confined to radical factions, rather, many of these campaigns drew widespread support from students, pacifists, Christians, trade unions, left wing groups and Maori organisations. Most of this political activity was confined to the four main cities: Auckland, Wellington, Christchurch and Dunedin. Due to the small size of the 'movement' in New Zealand, these various campaigns tended to overlap in terms of the individuals involved. To be involved in a certain campaign did not therefore preclude one from participating in another campaign, for example one could quite easily be associated with both the campaign against foreign 
military bases and the anti-apartheid movement. They were not insular and relied on a range of individuals, with varying politics and values to support the cause.

The time parameters for this study are determined by the years in which the Resistance Bookshops operated, 1969-1977. In 1969, the year the Auckland bookshop opened, political and countercultural activity in New Zealand intensified. Halt All Racist Tours (HART) and the Socialist Action League (SAL) were formed, new forms of radical protest were explored within the anti-Vietnam War movement, the first expressions of a women's movement appeared, the Save Manapouri campaign began to gain momentum and the 'Liberation' of Albert Park was staged in Auckland. Together these events shaped a protest culture which was largely created and defined by young, political people frustrated with the status quo. The last Resistance Bookshop to remain open was located in Wellington and closed around late 1976, early $1977 .{ }^{11}$ The late 1970 s saw a different political climate from the earlier period of the late 1960s. Protest was still a common occurrence in New Zealand in the late 1970s with anti-nuclear demonstrations, Bastion Point and environmental campaigns such as Whirinaki and Pureora gaining public attention. However, the particular type of protest culture which had defined the late 1960s to early 1970s had changed. The presence of the youth and counterculture movements which drew in many young people and had merged with aspects of earlier political movements, had for the most part disappeared by the late 1970s. After the withdrawal of New Zealand troops from Vietnam, the impetus for direct action weakened and there was no longer one overriding political issue which generated the same coalition of opposition. The change in government in 1975 also had an impact on protest culture. Prime Minister Robert Muldoon's leadership polarised public opinion, this coupled with an economic recession created additional challenges for the radical movement.

The Resistance Bookshops functioned in parallel to the vigorous political campaigning of the 1970s. However, while the campaigns functioned in a localised form, the political issues that were being addressed were very much part of a wider international protest culture. The strategies for mobilisation that were originally used by the civil rights and anti-Vietnam War movements in the United States in the 1960s

\footnotetext{
${ }^{11}$ The precise date that Wellington Resistance closed is unclear because the bookshop merged with Liberation Books, another left wing bookseller, in late 1976.
} 
influenced the form that protest took in New Zealand. New forms of protest like sitins and teach-ins were adopted by New Zealand protesters, who also appropriated many of the cultural aspects that had flourished alongside the 'movement' in the United States. Clothing, music, psychedelia, new 'far out' lingo and countercultural literature all found their way into New Zealand, and for many, these cultural expressions were just as important as the street politics as they represented an attempt by young people to build their own (counter) culture. While there was an interest in cultural expressions from the United States, there was also a strong desire by New Zealanders to both produce and have access to art, music and literature which represented a New Zealand perspective. This was particularly evident in the high level of sales that some of the local titles published by Alister Taylor achieved. Titles included Tim Shadbolt's Bullshit and Jellybeans (1971), which sold over 12,000 copies and The Muldoon Annual Jokebook (1971), which sold all 20,000 copies printed by March 1972; shown in figure 2. ${ }^{12}$ This was certainly a level of success that mainstream publishers would not have foreseen.

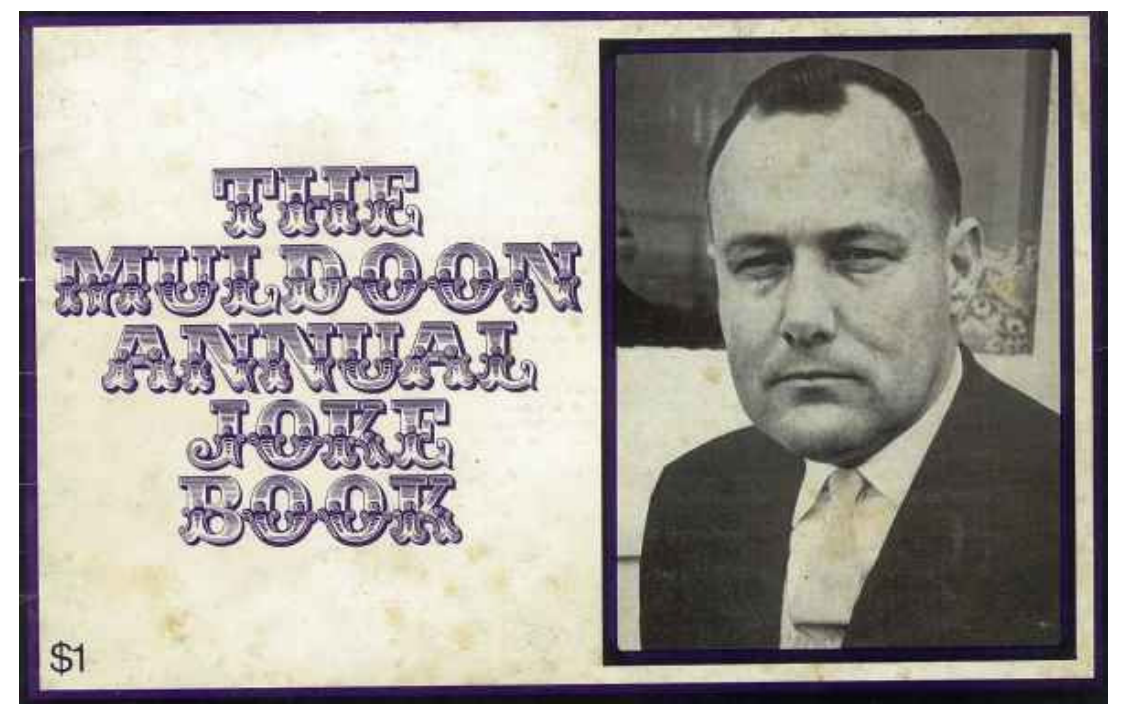

Figure 2 -Alister Taylor and Jim Barr, The Muldoon Annual Jokebook, Wellington 1971

There are two key arguments advanced in this thesis. The first proposes that the Resistance Bookshops played an instrumental role within the broader scope of the protest 'movement' in New Zealand. At a basic level the shops provided a space to

\footnotetext{
${ }^{12}$ Tim Shadbolt, Bullshit and Jellybeans, Wellington, 1971; Bruce Wallace, 'The Female Whirlwind', New Zealand Listener, 27 March 1972, Vol.69, pp.8-9; Alister Taylor and Jim Barr, The Muldoon Annual Jokebook, Wellington 1971; 'Book Review: The Little Red School Book', Craccum, University of Auckland, Vol.46, No.3, 16 March 1972, p.12.
} 
circulate radical material but they also had a broader role, which was to work within the wider 'radical space' of protest and radicalism to challenge the societal and political conventions which were condemned by many activists during the 1970s. The bookshops were able to participate in this culture of protest through the particular type of texts they sold and the campaigns that they supported. In order to test this premise, a number of key issues will be explored. Firstly, as the bookshops and the print distributed through the shops were largely products of the increased political activity of the 1970s, this study will examine how the bookshops operated within this culture of protest. The bookshops were set up to have a close relationship with political groups. The actuality of these relationships will be explored by examining in what ways the bookshops were connected to specific political campaigns, for example did groups use the available space at Resistance for meetings? Were the groups' newsletters distributed through the bookshops? Or did the bookshop stock material that would have been of direct relevance for the groups? This thesis will examine the question of whether the Resistance Bookshops had an important role in making material available which was central to 'raising consciousness' about political issues during the 1970s. The Resistance Bookshops' stock lists reflected the range of issues and campaigns that preoccupied politicised people in New Zealand. No one subject area predominated and the range of material filling the shops' shelves indicated that there was great multiplicity within the 1970s protest culture. Some of the political material stocked included Marxist theory and the writings of Third World liberation movement icons like Ho Chi Minh. Reading this political or 'subversive' material was a crucial part in enabling individuals to familiarise themselves with a greater body of political writing, and by reading widely, there was the potential to achieve a greater depth of understanding about global political issues.

The question raised about print as a key means for 'consciousness raising' links with the second part of this project's argument, which aims to examine the role of print within political movements. There is an important interplay between political movements and their print as it is a medium which groups can use to articulate their views, while having control over its production and distribution. There was a strong belief in the power of ideas and print was instrumental in enabling radical ideas to disseminate. The Resistance Bookshops wanted to raise consciousness about political issues, they wanted to change views and perceptions and the books, magazines and 
pamphlets that they stocked were a key means in doing this. Through the analysis of alternative and underground texts, the role that these sources had in challenging, persuading and encouraging people to participate in political actions will be examined. Questions will be raised about the impact that texts had on readers and why some texts, like Bullshit and Jellybeans for instance, were able to generate high circulation and readership levels. It is impossible to determine directly how readers interpreted and responded to political print but the sheer fact that this kind of print was continuously produced and imported into New Zealand is an important indicator that there was a great interest and value placed in this type of dissident print.

The body of literature that deals with New Zealand protest movements has increased considerably in the last decade with the publication of a range of single issue based histories. ${ }^{13}$ Many of these accounts have been written or edited by individuals who were directly involved with specific campaigns, for example Melani Anae was a Polynesian Panther, Trevor Richards headed the anti-tour organisation HART and Christine Dann was heavily involved with the women's movement. Most of these accounts were written at a distance from the actual campaigning and often offer a personalised reflection of the events. These histories place individual campaigns within the period of increased political activity in the 1970s but none entirely capture how the various strains of protest fit together to represent a 'radical space' or culture of protest more generally. For example Roberto Rabel's work on the anti-Vietnam War movement acknowledges the existence of broader social and political

\footnotetext{
${ }^{13}$ The historiography of single issue campaigns in New Zealand includes: Melani Anae (ed), Polynesian Panthers, Auckland, 2006; Toby Boraman, 'The New Left and anarchism in New Zealand from 1956 to the early 1980s: an anarchist communist interpretation', PhD Thesis (Political Science), University of Otago, 2006; Christine Dann, Up From Under: Women and Liberation in New Zealand, 1970-1985, Wellington, 1985; Julie Glamuzina, Out Front: Lesbian Political Activity in Aotearoa 1960-1985, Hamilton, 1993; Laurie Guy, Worlds in Collision: The Gay Debate in New Zealand 19601980, Wellington, 2002; Elsie Locke, Peace People: A History of Peace Activities in New Zealand, Christchurch, 1992; Grace Millar, “Because we are all women': the relationship between ideas of women's liberation and the development of the New Zealand feminist movement', MA (History), Victoria University of Wellington, 2003; Roberto G. Rabel, New Zealand and the Vietnam War: Politics and Diplomacy, Auckland, 2005; Stephen Rainbow, 'The Unrealised Potential of Green Politics: A study of four green parties', Victoria University of Wellington, PhD Thesis, 1991; Trevor Richards, Dancing On Our Bones: New Zealand, South Africa, Rugby and Racism, Wellington, 1999; Lucy Sargisson and Lyman Tower Sargent, Living in Utopia: New Zealand's Intentional Communities, Aldershot, 2004; Megan Simpson, 'Escaping the Isolated Suburbia Trip: Exploring the alternative lifestyle movement in New Zealand in the 1970s', BA (Hons) Research Essay in History, Victoria University of Wellington, 2005; Ranginui Walker, Ka Whawhai Tonu Matou Struggle Without End, Second Edition, Auckland, 1990; Roger Wilson, From Manapouri to Aramoana: The Battle for New Zealand's Environment, Auckland, 1982; David Young, Our Islands, Our Selves: A History of Conservation in New Zealand, Dunedin, 2004.
} 
movements but does not provide analysis of the impact of the anti-Vietnam War movement on other political campaigns. ${ }^{14}$ This is perhaps indicative of the nature of the protest during this period, campaigns were very much 'single issue' based, formed around specific issues rather than a broader ideology which transcended individual campaigns. The history of the Resistance Bookshops may be the setting to examine this best, as the bookshops acted as umbrella organisations aiming to bring together individuals associated with various groups and campaigns. With the exception of Christchurch, the limited success that the shops had in achieving this represents how difficult it was to bring together a series of political movements which were diverse, highly dynamic and in many cases sectarian.

Currently we know little about the three bookshops. A recent thesis and earlier article by Toby Boraman briefly addressed the role of the Resistance Bookshops within the 'New Left' in New Zealand. ${ }^{15}$ The Wellington shop was also mentioned in Redmer Yska's history of marijuana in New Zealand but no other scholarship has dealt with the bookshops, this type and period of cooperative bookselling or the role of dissident print within political movements in New Zealand in this period. ${ }^{16} \mathrm{We}$ can gain an insight into the wider culture of the left in New Zealand through collections edited by John E. Martin and Kerry Taylor (1991) and Pat Moloney and Kerry Taylor (2002). ${ }^{17}$ While the focus of both books is more wide-reaching than the timeframe for this thesis, they are both useful as they address the role that the left has played within New Zealand's political history.

As well as contributing to a new facet of New Zealand's radical history, this project also expands on our existing knowledge of the radical political activity of the 1970s. The thesis draws links between the various strains of radical protest, demonstrating that there were interconnections between campaigns and the individuals involved with groups associated with particular campaigns. It also briefly highlights that protest

\footnotetext{
${ }^{14}$ Rabel, 2005, p.285.

${ }^{15}$ Boraman, 2006; Toby Boraman, 'The New Left in New Zealand', in Pat Maloney and Kerry Taylor (eds), On The Left: Essays on Socialism in New Zealand, Dunedin, 2002, pp.117-132. Boraman, Rabble Rousers and Merry Pranksters: A History of Anarchism in Aotearoa/New Zealand from the mid 1950s to the early 1980s to be released in October 2007.

${ }^{16}$ Redmer Yska, New Zealand Green: The Story of Marijuana in New Zealand, Auckland, 1990, p.124.

${ }^{17}$ John E. Martin and Kerry Taylor (eds), Culture and the Labour Movement, Palmerston North, 1991; Pat Moloney and Kerry Taylor (eds), 2002.
} 
activity had regional variations, for example some issues had more intensified activity occurring in particular cities. The thesis also explores the multiplicity of the protest culture in New Zealand, there were a diverse range of political movements, with many campaigns occurring simultaneously during the 1970s. As discussed earlier, the histories of these movements are generally 'single issue' based, which does not reflect the fact that these campaigns were part of a broader culture of protest which was interconnected due to the individuals supporting the campaigns. The Resistance Bookshops were spaces in which individual political directions intersected. This is one of the key reasons why the Resistance Bookshops have an important place within the wider scope of the history of radical political activity during the 1970s. Overall the histories of the shops highlight some of the interconnections that existed and emphasise the relatively small size of the protest culture in New Zealand during the 1970s.

The power of print to mobilise for change is a topic which has been examined by historians of book history. Since the beginning of the 1980s a great deal of scholarship has been produced on the history of books and reading. Scholars including Robert Darnton, Roger Chartier, Jonathon Rose and Don McKenzie have explored a range of topics from print culture, bookselling, the function and form of texts, through to the experience of the reader. ${ }^{18}$ Roger Chartier has examined the relationship between print and subversive public opinion by juxtaposing the arguments of Robert Darnton and Arlette Farge. ${ }^{19}$ Darnton argued that in the context of the French Revolution, print was a key means to communicate and instil seditious sentiment among the public. However, Farge's earlier argument countered Darnton's claim, by arguing that dissident public opinion already existed and pamphlets which were produced and circulated found an audience that was already sympathetic to the ideas contained in such print. ${ }^{20}$ The issue of the power and influence of print as posed

\footnotetext{
${ }^{18}$ Some titles include Guglielmo Cavallo, and Roger Chartier, A History of Reading in the West, Amherst, 1999; Robert Darnton, The Great Cat Massacre: And Other Episodes in French Cultural History, New York, 1984; Jonathon Rose, The Intellectual Life of the British Working Class, New Haven and London, 2001; Donald F. McKenzie, Bibliography and the Sociology of Texts, Cambridge, 1999.

${ }^{19}$ Roger Chartier, On The Edge Of The Cliff: History, Language and Practices, Baltimore and London, 1997, p.75; Robert Darnton, The Forbidden Best-sellers of Pre-Revolutionary France, New York, 1995; Arlette Farge, Subversive Words: Public Opinion in Eighteenth-century France, Cambridge, 1994.

${ }^{20}$ Chartier, p.75.
} 
by Darnton and Farge also raises important questions for this study. A central question that this thesis examines is the role of print within political movements. What is difficult to assess, however, is the actual influence that print has on the reader. Are publications responsible for persuading, challenging and shaping a reader's beliefs and actions? Or rather does print merely strengthen pre-existing beliefs? The question of whether print can alter the views of the reader is pivotal to this study. It is a question that is extremely difficult to answer, however one can draw links between the consumption of political texts and the increasing level of political mobilisation during the 1970 s.

A rich, if fragmented, collection of documentary sources was available for this project. The major body of primary sources came from a series of personal papers and underground publications held privately at the outset of this research. This collection, entitled the Tom Fanthorpe Memorial Library (TFML), is a collection of ephemera and correspondence that was collected by the Resistance Bookshop in Wellington. Throughout the 1980s and 1990s, the collection has been looked after by various anarchists in Wellington, most of whom were not involved with Resistance. The collection was made available to the author through personal contacts and will be deposited in the Hocken Library soon after submission. Boraman has reported that the library was named after Tom Fanthorpe, a mythical spokesperson created by the Wellington Progressive Youth Movement (PYM) for its dealings with the media. ${ }^{21}$ The collection includes a range of leaflets, newsletters, posters, magazines, newspapers and correspondence that was sent between the three Resistance Bookshops. The material ranges from local political groups' newsletters through to newspapers imported from the United Kingdom. The assortment of ephemera and correspondence gives a good indication of the types of campaigns that the shops were associated with and the range of issues that the shops stocked information about. The other major primary sources that were used were the underground magazines produced in New Zealand from the late 1960s until the mid 1970s. These publications were deposited at the National Library at the time of publication; the producers of magazines like Cock, Earwig and Itch all studiously deposited copies at the library, abiding by their legal obligation to do so. The remaining documentary sources

\footnotetext{
${ }^{21}$ Boraman, 2006, p.283.
} 
comprised largely of ephemera collections located in the Alexander Turnbull Library (ATL), these collections contain similar material to the TFML but cover a greater range of political activity from around New Zealand.

While these sources provide a good indication about the range of political issues and type of language used by political groups, they do not really give a sense of the vitality and character of the Resistance Bookshops. In order to gain first hand impressions of people's involvement with the bookshops, interviews were conducted with six individuals who were involved with Resistance. These interviews involved only a small number of people and selection was determined by those individuals who were easily contactable and were willing to participate. The views presented are by no means representative of all individuals who were involved; other individuals would no doubt have different recollections about their time at the shops. Interviewees were questioned about their experiences at the Resistance Bookshops, their recollections about organisational structures, the types of print sold, the relationship between Resistance and political activity going on in the city and any successes or failures that they felt the bookshops had. As all the interviewees were heavily involved with various political activity at the same time that they were involved with the bookshops, their experiences highlight the important role that the bookshops served within the wider 'movement'. ${ }^{22}$ As is common with oral history, the memories recounted are fragmented and partial but they provide important insights into the workings of the bookshops and help to fill in and expand on the documentary sources. ${ }^{23}$

This project is split into three chapters. Chapter one examines the 'radical space' in which the bookshops existed, providing a brief chronology and description of the political activity occurring in New Zealand during the 1960s and 1970s. This discussion places the Resistance Bookshops within the context of the contemporary protest culture. During this period a number of political and social movements emerged ranging from anti-apartheid to women's liberation through to opposition to foreign military bases in New Zealand. However, the range of political campaigns occurring simultaneously in New Zealand have not previously been discussed

\footnotetext{
${ }^{22}$ Many of the people interviewed continue to be politically involved, from those still working on campaigns at a grassroots level to those involved with parliamentary politics.

${ }^{23}$ Anna Green and Megan Hutching, Remembering: Writing Oral History, Auckland, 2004, p.11.
} 
alongside each other. This chapter will argue that the political campaigns in New Zealand were interconnected and the experience that individuals gained through various mobilising and lobbying flowed on through to other movements and campaigns. The Resistance Bookshops were established by activists to support and inform individuals involved with political activity that was occurring in each of the cities. The shops were born out of the need to have a space that could support and foster radical activity. This chapter will explore how the shops were connected with the wider protest culture of this period.

Chapter two looks at the Resistance Bookshops, examining the structures, aims and activities behind the three radical spaces. This chapter will look at the individuals involved, the process for setting up the shops, the material sold and produced, the organisational and management structures, the relationships that the shops had with political groups and some of the problems that occurred. By comparing and contrasting the three Resistance Bookshops it is evident that each shop had vastly different relationships with political groups in each of their respective cities. This is important in terms of this study because it shows that there were regional differences within political movements in New Zealand, rather than there being a cohesive, nationwide protest 'movement' during the 1970s. By focussing specifically on the Resistance Bookshops, this chapter will demonstrate how the bookshops operated within the political climate of the 1970s, looking at their ties with other political groups and their attempts to challenge cultural taboos through the texts they circulated and the direct action that they supported.

Chapter three examines the relationship between print and political movements, looking at the role of the Resistance Bookshops in distributing political material during the 1970s. The bookshops were spaces in which local political groups could circulate their newsletters and customers could purchase political texts imported from around the world. Much of this print was sold by or circulated through the Resistance Bookshops and remains an important cultural artefact for a 'movement' that used print as a key medium for expression. Print was a key means for young radicals and political groups to communicate; production was increasingly cheap and print allowed the author the freedom to present their ideas, thoughts and politics through their own channels. This chapter will examine the production, distribution and circulation of 
alternative and underground print in New Zealand, looking at the content, language, graphics, stylistic elements and the impact that this type of print culture had. This chapter focuses on how print is received, its ability to persuade and even change the reader and whether the print that was produced during this period actually succeeded in doing so. Together these three chapters indicate that the Resistance Bookshops were more than simply booksellers, their purpose was wider and discussing them in relation to other political organisations, patterns of bookselling and the role of dissident print acknowledges the unique role that Resistance had within the 'radical space' of the 1970s. 


\section{Chapter One \\ Print, Protest and Politics: The Resistance Bookshops and the wider culture of protest in New Zealand, 1969-1977}

New Zealand in the 1960s was a very conservative society. It was a nation that was still defined by the 'rugby, racing and beer' ethos, with relatively tight controls over what films, books and music were available. ${ }^{1}$ However, the 1960 s also brought with it a point of major change. The changing political climate, which had begun with the actions of the Campaign for Nuclear Disarmament (CND) and culminated with the opposition to the Vietnam War in the late 1960s, produced a protest culture which would eventually result in thousands of New Zealanders mobilising against the war. This culture or 'radical space' would ultimately evolve into numerous social and political movements, drawing in a diverse support base, which included dozens of young radical protesters who became the most controversial face of the protest activity during the late 1960s to the mid 1970s. This increased level of political activity was a key ingredient in the formation of the Resistance Bookshops. The following analysis of the political and countercultural movements in New Zealand will outline the setting out of which the Resistance Bookshops arose. The rising political 'movement' in New Zealand highlighted the need for a place to obtain radical literature and also drew attention to the need for political groups to have a space in which to organise. The formation of the Resistance Bookshops attempted to resolve these two problems.

The post-war period saw many changes in New Zealand society. The booming economy in the 1950s brought with it prosperity and increased consumerism. A youth subculture also emerged in the 1950s, predominantly influenced by American culture, notably rock 'n' roll, milk bars, books and films. ${ }^{2}$ Parents were aghast as stories of teenage sex, murder and immorality appeared in some headlines, but New Zealand society was changing. The presence of a youth subculture would continue to be a permanent feature of society into the 1960s, with youth challenging repressive

\footnotetext{
${ }^{1}$ James Belich, Paradise Reforged: A History of the New Zealanders from the 1880s to the year 2000, Auckland, 2001, p.463.

${ }^{2}$ For discussion of New Zealand in the 1950s see Redmer Yska, All Shook Up: The Flash Bodgie and the Rise of the New Zealand Teenager in the Fifties, Auckland, 1993; for coverage of rock ' $n$ ' roll in New Zealand during the 1950s see John Dix, Stranded in Paradise: New Zealand Rock and Roll, 1955 to the Modern Era, Second Edition, Auckland, 2005.
} 
conventions and cementing a younger generation as important consumers. As the baby boomers grew up, the 1960s saw a huge increase in the number of people attending university. In 1950 13,620 people attended university and teachers' colleges, by 1969 this had grown to 38,406, a more than two hundred per cent increase in enrolments. ${ }^{3}$ University attendance brought with it exposure to new ideas and politics and student newspapers provided a forum for students to probe topics and issues relating to both the student population and the wider political climate.

The increase in university attendance was an important ingredient in the development of the 'radical space' that emerged in the late 1960s though to the mid 1970s. While students were just one section of protesters that mobilised for causes like the antiVietnam War movement, they represented a large proportion of people who were prepared and able to involve themselves in direct action. Political groups sprang up on campuses around the country, student newspapers covered political topics in great depth and many people gained their 'political awakening' while attending university. The Resistance Bookshops were all set up with close links to the universities in each city. While the shops were not run exclusively by students, many of those involved either were attending or had attended university at some point, many of their customers were students and all three bookshops received coverage within each of the university student newspapers: Craccum (University of Auckland), Salient (Victoria University of Wellington) and Canta (University of Canterbury).

As outlined in the introduction, the 'radical space' in which the Resistance Bookshops operated was a particular kind of political and cultural momentum which for many, arose out of the imagination and aspirations of youth sceptical of the 'Establishment'. This momentum is often referred to as a 'movement'. This term was first used in the United States and was applied as an umbrella phrase describing the range of political activity that was surfacing throughout the Western world. It has been used widely in American historiography of this period. ${ }^{4}$ In this context, the term denotes a particular

\footnotetext{
${ }^{3}$ David C. Thorn and Charles P. Sedgwick, Understanding Aotearoa/New Zealand: Historical Statistics, Palmerston North, 1997, p.144.

${ }^{4}$ There is a great body of research written on the 'movement' in the Unites States. This includes: Terry H. Anderson, The Sixties, Second Edition, New York, 2004; Alexander Bloom (ed), Long Time Gone: Sixties America Then and Now, New York, 2001; David Farber (ed), The Sixties: From Memory to History, Chapel Hill and London, 1994; Todd Gitlin, The Sixties: Years of Hope, Days of Rage,
} 
type of political activity, comprising mostly young people, with countercultural and anti-Establishment aspirations. The term was used to encapsulate the larger force of politics, protest and debate and covers a huge multiplicity of campaigns, methods and political and moral affiliations.

However, the term 'movement' is problematic because it is difficult to ignore its undertones of cohesion. In New Zealand, the notion of a 'movement' exists largely because there was an increased level of political activity occurring from the late 1960s until the early 1970s. However, this 'movement' was as much a series of single issues or campaigns, linked primarily by the overlap of individuals involved. It needs to be noted that the term 'movement' is being used in this study because it is a simple way to represent both the scope of political activity and the general atmosphere of opposition to the 'Establishment'. To describe the political activity of this period as a 'movement' is not to homogenise the aims of the various groups involved or to represent them as being involved in a singular unified campaign. Rather, the term is useful because it transcends the diverse, changeable and often messy political divisions and directions. It can also be used to signify the type of street politics and appeal for social change that was gaining momentum during this period. The term is also suitable because it was used contemporaneously by those groups and individuals publishing alternative or 'underground' publications

The political activity associated with the Resistance Bookshops and the groups that used the space can be defined as 'radical' political activity for two reasons. Firstly, activists were advocating widespread social change, from the personal level of liberalised sexual conventions through to fundamental change at a governmental level, with some people even pursuing a socialist revolution. The radical agenda and direction of activists meant that societal conventions were challenged, with different lifestyles and notions of morality being explored. Secondly, the form and methods that were explored by activists to bring about this social change were also radical. People adopted confrontational forms of protest, particularly street demonstrations, which sometimes resulted in violent clashes with police. Some individuals even dabbled with bomb-making, an extreme act which was not necessarily supported 
within radical circles. These methods demonstrated ways in which traditional parliamentary lobbying was being abandoned for more radical forms of resistance.

This 'movement' was diverse in direction and methods but those establishing the Resistance Bookshops saw that there was a need to establish spaces where people with an interest in radical politics or countercultural ideals could gain access to the type of print which explored ideas behind the protest culture. While diverse, there were some common goals or ideals that were embraced and advocated by political groups regardless of their political persuasion. These ideas were a mix of leftist beliefs, anarchist principles of freedom and countercultural idealism. One of the strongest characteristics of the 'movement' was its anti-authoritarian stance. Alternative or 'underground' print was a clear expression of this anti-authoritarian position. 'Underground' publishers, who were essentially alternative media sources, used the medium of print to challenge and critique conventions imposed on society by the 'Establishment'. Another common position was a critique of capitalism, stemming from a backlash to the increasing level of consumerism and materialism in New Zealand. However, while protesters rejected contemporary culture that seemed to revolve around an excessive need to consume, commercialism was not rejected fully, with the prime example being the Resistance Bookshops, in which collectives established businesses in order to support, educate and fuel political activity.

The radical politics which underpinned protest culture of this period varied from individual to individual and group to group and because of this the Resistance Bookshops chose not to adopt a set political position or ideology in an attempt to appeal to all people of all left wing positions. The issue of ideological divisions was a crucial factor in limiting cohesion or unity within the 'movement'. Divisions existed between Trotskyists and Leninists, between Marxists and Anarchists and between the 'Old Left' and 'New Left'; this meant that places, like the Resistance Bookshops which attempted to overcome these ideological divisions often had major difficulties in doing so. The term 'Old Left' represented the traditional organisations of the left, groups like the Communist Party of New Zealand (CPNZ), which placed emphasis on knowledge of Marxist writings, party allegiance and trade union support to bring about revolution. 'New Left' however, was a key political ideology associated with the 'movement' of the late 1960s. The term represented an international movement, 
which rejected traditional 'Old Left' forms of resistance and relied instead on the concept of 'participatory democracy', an idea where people actively took part in critiquing society and politics. ${ }^{5}$

The Resistance Bookshops were more closely connected to 'New Left' ideology than 'Old Left' but it is important to note that during the late 1960s and early 1970s, the term 'New Left' was not used by groups in New Zealand. ${ }^{6}$ It was a term that was linked more to the 'movement' in the United States where groups like the Students for a Democratic Society (SDS) defined themselves as 'New Left'. In New Zealand, there was no defined 'New Left' similar to that which existed in the United States, however while the term tended not to be used contemporaneously, it was used by interviewees when describing the type of politics Resistance was engaged with. The 'New Left' turned away from traditional icons of revolution like Lenin and celebrated new revolutionary leaders and 'freedom fighters' like Mao Tse-tung, Che Guevara and Ho Chi Minh. While the bookshops still sold 'Old Left' texts, books and posters celebrating the icons of the 'New Left' were also imported and sold by the bookshops.

The 'Old Left' was still very much present within the 'radical space' of the 1960s and 1970s. While the organisations associated with the 'Old Left' did not always use the Resistance Bookshops, they were highly active within many of the political campaigns of the time. There were three major organisations which can be defined as 'Old Left' due to their adherence to different strains of leftist ideology: the CPNZ, the Socialist Unity Party (SUP) and the Socialist Action League (SAL). The Sino-Soviet split in 1965 divided the left in New Zealand. The CPNZ adopted Chinese Communist ideology as the prevailing ideology, which fractured the party and consequently led to the formation of the SUP, a pro-Soviet party that advocated the idea of 'peaceful coexistence'. The SAL was formed in 1969 and was the largest Trotskyite organisation in the country; pursuing the idea of building the 'permanent revolution'. Aside from these three organisation there were a series of other smaller groups like the Spartacist League, which was a very small Trotskyite faction consisting mostly of students. In 1972 the Spartacists split into two Wellington based factions, the Red Faction headed

\footnotetext{
${ }^{5}$ Wini Brenes, “'Of This Generation”: The New Left and the Student Movement' in Alexander Bloom (ed), Long Time Gone: Sixties America Then and Now, New York, 2001, p.26.

${ }^{6}$ See Boraman, 2006 for discussion of the New Left in New Zealand during the 1960s and 1970s.
} 
by Owen Gager and Bill Logan's faction. ${ }^{7}$ These groups, while all leftist, had immensely different ideas about how a revolution would be achieved and the necessary societal changes that would be required to implement it. These 'Old Left' organisations often disagreed with the actions and political directions of the 'New Left' but there was continued association between the factions. As the Resistance Bookshops would find out, the sectarian nature of these political lines meant that interaction between the various factions was limited, with the SAL tending to stay away completely from Resistance. The SAL also clashed with HART over protest tactics. While SAL advocated peaceful demonstrations, HART tended to utilise "nonviolent disruption" as a means to oppose the apartheid policies of South Africa. ${ }^{8}$

The political momentum which thrived for a time in New Zealand from the late 1960s, had links to a much wider international 'movement', which was inspiring young people and radicals around the western world. The events in Paris in May 1968 were a defining moment for youth and political movements internationally. The student riots and nationwide strike that transpired in France showed young radicals around the world the potential of mass mobilisation and street politics. ${ }^{9}$ In New Zealand, the events of May 1968 were said to fuel the budding movement, with poet Alan Brunton recalling that the "effect of the Paris revolt in university coffee-bars here was electric. A group of students had almost brought down a government! Strategy talks, fuelled by amphetamines, lasted for days. Constitutions for new states, all utopian, were written". ${ }^{10}$ While not all students would have reacted in such a way, the young radicals who were involved with radical groups like the Progressive Youth Movement (PYM) were undoubtedly inspired by the events in France. Along with the French student uprising, 1968 would see young people and the left revolt in Prague, Chicago, Mexico City, Warsaw and Rome. The "events of 1968 had globalized political radicalism" and in New Zealand, the effect of this youthful rebellion was not overlooked. ${ }^{11}$ Poet Stephen Chan has suggested that New Zealand's counterpart to

\footnotetext{
${ }^{7}$ Boraman, 2006, p.262.

${ }^{8}$ Richards, p. 210.

${ }^{9}$ For discussion of the events of May 1968 see Tariq Ali and Susan Watkins, 1968: Marching in the Street, New York, 1998; Carole Fink, Philipp Gassert and Detlef Junker (eds), 1968: The World Transformed, Cambridge and New York, 1998; Tony Judt, Postwar: A History of Europe Since 1945, London, 2005.

${ }_{10}^{10}$ Alan Brunton, Years Ago Today: Language and Performance: 1969, Wellington, 1997, p. 23.

${ }^{11}$ Ali and Watkins, 1998, p.7.
} 
May 1968 happened in March 1969, when approximately a dozen students staged the country's first sit-in at the United States Consulate in Auckland in protest against the Vietnam War. ${ }^{12}$ This radical act displayed the new tactics that protesters were adopting and, in the years following, anti-war mobilisations would take place on an unprecedented scale.

The Vietnam War was undeniably the overriding political issue which dominated the protest culture in New Zealand from the late 1960s, till the early 1970s. It was a political movement in which many people gained their first experience with street politics. For the two years that the Resistance Bookshop operated in Auckland, it was the Vietnam War which was the stimulus for much of the large support base it attracted. The decision to commit New Zealand troops to combat in Vietnam in May 1965 began period of protest that manifested itself in ways not previously seen in New Zealand. While gaining the attention of older groups like the CPNZ and New Zealand Peace Council, the anti-war cause also spawned new groups that drew in a large number of supporters. Of the many organisations that were established in opposition to the Vietnam War, the Committees on Vietnam (CoV) were an important expression of the anti-war movement, as their membership comprised academics, students, trade unionists, church goers and peace activists, all working together to oppose New Zealand's involvement in Vietnam. ${ }^{13}$ The first branch, the Wellington CoV, was set up in April 1965, with several other branches set up in Auckland, Palmerston North, Nelson, Christchurch and Dunedin. Each branch was substantially different, comprising different support bases and each organisation suffering from their own divisions and limitations. ${ }^{14}$ The committees produced publications, held meetings, and took part in street protests and picketing. They were not a national, centralised body that coordinated the anti-war campaign, rather they were a number of loosely aligned groups that shared the similar aim of ending New Zealand's military role in the occupation of Vietnam. These committees varied regionally, with each committee having different levels of success in uniting their group. Rabel has noted

\footnotetext{
${ }^{12}$ Stephen Chan, 'Political Radicalism and Radical Literature: Usurpation and Incorporation in the New Zealand Literary World from 1969', Silver Jubilee Triennial Conference of the Association for Commonwealth Literature and Language Studies, University of Kent, August 1989, New Zealand Electronic Poetry Centre, University of Auckland; http://www.nzepc.auckland.ac.nz/misc/chan.asp; accessed on 29 January 2007.

${ }^{13}$ Rabel, 2005, pp.107-8.

${ }^{14}$ ibid., p.108.
} 
that both the Auckland and Christchurch committees were divided ideologically, while Wellington's committee was generally united..$^{15}$ These regional variations also presented themselves while the Resistance Bookshops were operating. However, for the bookshops it was only Christchurch that was able to successfully establish itself at the core of the active left in the city.

Aside from the CoVs, there were other groups that were formed as a response to the Vietnam War. They included the Peace for Vietnam Committee (PFVC), an Auckland group supported by the 'Old Left' and the Auckland Peace Council; Peace for Vietnam Committee (PFVC) an Auckland based Socialist/pacifist group and the Organisation to Halt Military Service (OHMS), a nationwide group which lobbied against 'national service' rather than the Vietnam War directly. OHMS was established in the latter stages of New Zealand's involvement in Vietnam, in February 1972, and opposed the selective compulsory military training which had been reinstated by the National government in 1962. Fifteen branches of OHMS were established throughout the country and the group's membership comprised largely young men balloted for the compulsory training. ${ }^{16}$ The group collected signatures in support of the abolition of national service and received a great deal of support from the community, with many clergymen supporting the campaign. ${ }^{17} \mathrm{~A}$ number of individuals involved with Resistance in Christchurch were also involved with the Christchurch branch of OHMS. Both Marty Braithwaite and Brian Newman, before getting involved with Resistance, had been prosecuted for non-compliance in September 1972. ${ }^{18}$ These various protest groups indicate that opposition to the war was not confined to radical groups. While the Resistance Bookshops tended to be in closer contact with the more radical face of the anti-war movement, they were all part of the same campaign to end the war regardless of the tactics and rhetoric adopted.

\footnotetext{
${ }^{15}$ Roberto G. Rabel, 'The Vietnam Antiwar Movement in New Zealand', Peace \& Change, January 1992, Vol. 17, No.1, pp.10-2.

${ }^{16}$ OHMS to the Australian Draft Resisters Union, undated, 'Organisation to Halt Military Service' MSS 068, Box 2, Folder 3, Item 31, JC Beaglehole Room, Victoria University of Wellington (VUW).

${ }^{17}$ Signatures in support of the abolition of national service, 'Organisation to Halt Military Service' MSS 068, Box 2, Folder 3, Item 39, JC Beaglehole Room, VUW.

${ }^{18}$ Christchurch OHMS to Wellington OHMS, 19 September 1972, 'Organisation to Halt Military Service’ MSS 068, Box 2, Folder 3, Item 39, JC Beaglehole Room, VUW.
} 
Between 1970 and 1972, the levels of anti-Vietnam War mobilisations increased considerably and involved a wide range of people. Some were connected with churches, trade unions, political parties and high school students, while others were socialists, feminists and pacifists. Regardless of their background, they all took to the street to demonstrate against the American invasion of Vietnam and Cambodia. In April 1965, when the first anti-war demonstrations were held, only around one hundred people participated in picketing the visit of the United States special envoy, Henry Cabot Lodge. ${ }^{19}$ By 1971, when the anti-war movement gained its greatest levels of support, a particular high point for the movement were the demonstrations held on 30 April throughout the country. These demonstrations reportedly mobilised 29-35,000 people..$^{20}$ Aside from encouraging an unprecedented number of people into participating in direct action, the anti-war campaign also introduced a range of new forms and strategies for protest. Mobilising tactics and strategies used by protesters expanded, with activists demonstrating on the streets and at public events, using placards and chanting to declare their outrage. People staged sit-ins at sites like university administrations and foreign embassies, held teach-ins about key issues, and put up posters and painted political messages on roads, RSAs and other public spaces. Some more radical individuals even explored bomb making and throughout 1969 and 1970 several government, sporting and defence sites were attacked in Auckland and Wellington. ${ }^{21}$ No longer were letter writing and petitions the only way to apply public pressure on the government. Street politics were designed to shock and confront, they were louder, more visible and had the ability to reach a wider public than ever before.

The 'radical space' of which the Resistance Bookshops were a product was much more than just a result of the political activity associated with opposition to the Vietnam War. While the culture of radical protest encompassed a number of independent political campaigns, it also included the increasingly multifaceted popular counterculture, which captured the attention of many young people.

\footnotetext{
${ }^{19}$ Rabel, 2005, p.106.

${ }^{20}$ ibid., p.309.

${ }^{21}$ Bomb making was discussed in Bullshit and Jellybeans, some examples given included dynamite bombs, smoke bombs and fire bombs, none caused extensive damage. Shadbolt, p.128. This more extreme or militant form of protest had links with political activity in the United States, specifically the Weathermen (or Weather Underground as they were later known) which were a group that carried out many high profile attacks on police stations and defence sites from 1969 until 1977. See Dan Berger, Outlaws of America: The Weather Underground and the Politics of Solidarity, Oakland, 2006 and Sam Green and Bill Siegel, The Weather Underground, 92 Minutes, Free History Project, New York, 2004.
} 
Auckland, particularly the University of Auckland campus, became a central site for political activity, with student activist Tim Shadbolt grabbing the attention of students and activists alike. Shadbolt and several others, including Alan Robson, who was involved with setting up the Resistance Bookshop in Auckland, were involved with organising 'Jumping Sundays' in Albert Park, an event which poet Alan Brunton described as "people all dressed up...playing recorders and throwing liquorice-allsorts at everybody else and a bit of face-paint on". ${ }^{22}$ Shadbolt also formed groups like AUSAPOCPAH, (Auckland University Society for the Active Prevention of Cruelty to Politically Apathetic Humans), and its successor the Friends of Brutus, which were involved with anti-Vietnam protests and countercultural festivities more generally. Both groups used "loud, extravagant, colourful" tactics including anti-Establishment rhetoric and street theatre both of which had links with the approach shaped by the Yippies in the United States. ${ }^{23}$

These strategies were also employed by the PYM, another group that championed the anti-war cause. The PYM consisted of several groups around the country, comprising a number of radical, young people, many of whom became heavily involved with the Resistance Bookshops. The PYM were not exclusively anti-Vietnam War organisations but they did become a high profile and polarising face of the anti-war campaign in New Zealand. The first group was formed in Auckland in 1965 and subsequent branches were established in Wellington, Christchurch and in other smaller centres like Napier. While the groups shared a name, there was no centralised form of control or manifesto, each branch was independent and had varying affiliations with the left. In recalling the heyday of the PYM, Murray Horton, who was involved in Christchurch, noted that the "Auckland PYM was aligned with the Communist Party; things were much looser in Christchurch". ${ }^{4}$ Branches in Auckland, Wellington and Christchurch each produced publications containing information about demonstrations and relevant political topics. Issues tended to be produced infrequently and in the early days of the bookshops, when the PYM was still active,

\footnotetext{
${ }^{22}$ Alan Brunton interviewed by Chris Bourke, September 2000, New Zealand Electronic Poetry Centre, University of Auckland; http://www.nzepc.auckland.ac.nz/authors/brunton/brief/bourke.asp; accessed 13 February 2007.

${ }^{23}$ Alan Brunton, Murray Edmond, Michele Leggott (eds), Big Smoke: New Zealand Poems 1960-1975, Auckland, 2000, p.322.

${ }^{24}$ Murray Horton, 'Radicals In Retrospect', New Zealand Monthly Review, Vol.33, August/September 1991, p.30.
} 
copies of the PYM's publications were sold at the Resistance Bookshops. Within the PYM there tended to be a dis-unity of ideas, there was no concrete political line and generally there was not a deep understanding of leftist works. ${ }^{25}$ The PYM in Wellington reinforced the importance of not being bound to "ideological straitjackets" arguing that "rigid manifesto type movements can only lead to a greater degree of alienation between politicos and dropouts". ${ }^{26}$ Although the branches of the PYM disbanded between 1970 and 1972, many of its members went on to become involved with the Resistance Bookshops.

The PYM employed quite distinctive tactics from other protest groups in New Zealand. It was quite 'media savvy' and utilised the media to promote the anti-War cause. Strategies like street theatre and public stunts generated an enormous amount of media interest around the group. There were a number of high profile examples of provocative PYM actions, including when the Christchurch PYM laid a wreath on ANZAC Day in 1970 as a protest against the glorification of war. ${ }^{27}$ The wreath was removed and ripped up by the Christchurch Mayor Ron Guthrey, who commented that "Dumb, longhaired louts who have nothing to contribute to our society - who damn everything that we have ever fought for - must not be allowed to insult our war dead" ${ }^{28}$ The Wellington PYM also utilised public displays, on one instance staging a procession down a major Wellington street, in which they carried four coffins as an act of solidarity after the Kent State Massacre in the United States in $1970 .{ }^{29}$ In the same year they also burnt an effigy of Richard Nixon outside Prime Minister Holyoake's home, an act which was captured by television cameras. These highly visible demonstrations enabled the PYM to bring their political position to an elevated platform. Even if media reports were often scathing and they were treated as a radical fringe faction, it gave them a great level of publicity in which to draw attention to the growing opposition against the Vietnam War. Figure 3 is an example of the

\footnotetext{
${ }^{25}$ Chris Kraus, interviewed in Russell Campbell, Rebels in Retrospect: The Political Memoirs of some members of Christchurch and Wellington PYM: in 19 parts, 74 Minutes, Vanguard Films, Wellington, 1991.

26 'Drugs, Politics and the PYM', PYM Rabble, No.3, August 1970, p.11.

${ }^{27}$ Campbell, 1991.

${ }^{28}$ Ron Guthrey, 25 April 1970, Christchurch, quoted in PYM Rabble, No.2, Wellington PYM, June 1970, p.2.

${ }^{29}$ On 4 May 1970 the National Guard opened fire during an antiwar protest at Kent State University. Four students were killed, including 2 students who were not involved in the demonstration. 'Coffins laid Outside USIS', PYM Rabble, No.2, Wellington PYM, June 1970, p.8; Therese O'Connell, interviewed in Campbell, 1991.
} 
sensationalist media coverage that was directed at radical groups, in this instance the Radical Election Campaign (REC) was the target, a group which will be discussed in chapter two.

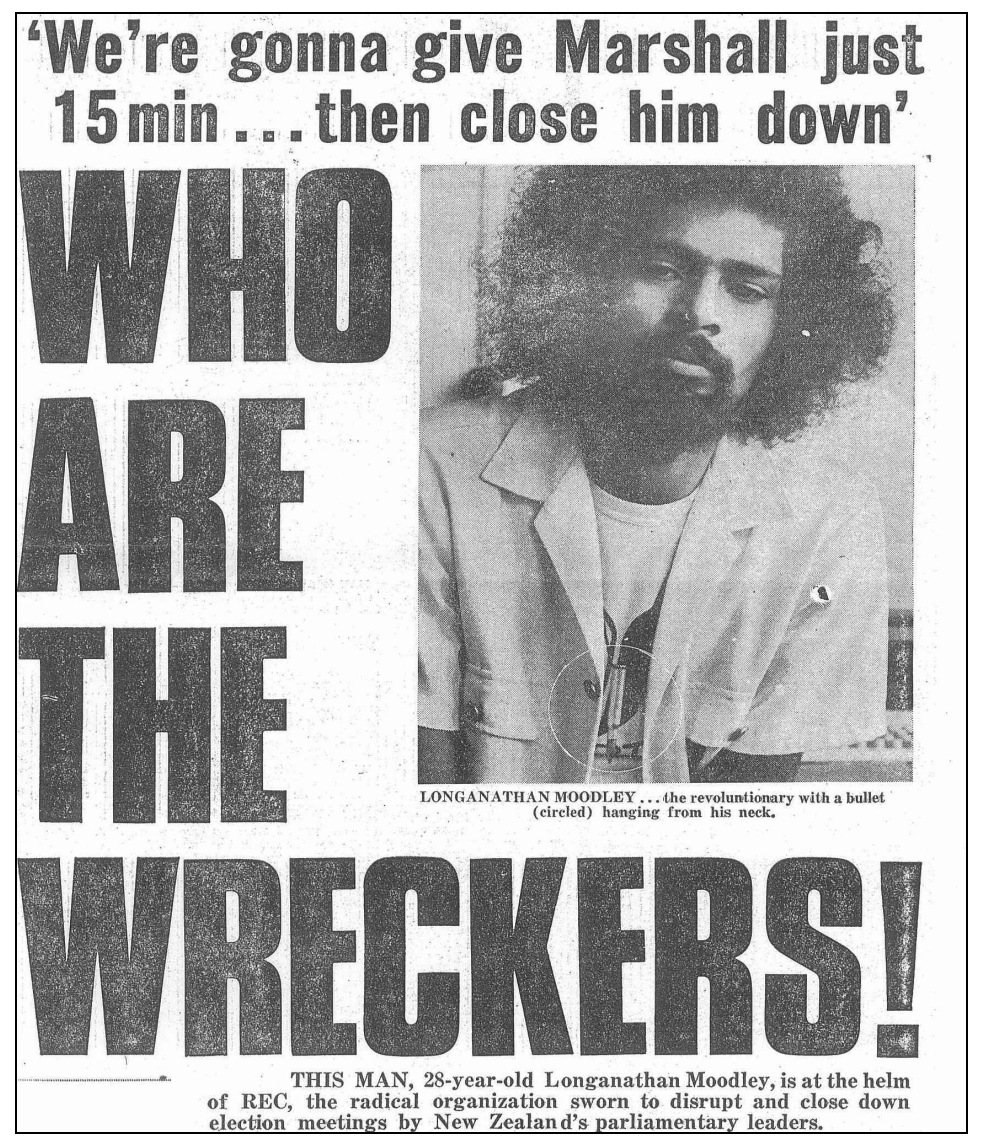

Figure 3 - Often radical groups were subject to sensationalist media coverage. In this example, an individual associated with the Resistance Bookshop in Auckland and Radical Election Campaign gained the attention of the mainstream media, due to his use of militant rhetoric and the bullet he wore around his neck. The group had threatened to disrupt election meetings due to the issue of sporting contact with South Africa

'Who Are the Wreckers!: The Disrupters Close-Up', 8 o'clock Auckland Star, Auckland, 11 November 1972, p.1.

As the radical protest culture of the 1970s comprised a number of single issue based campaigns, it can be argued that the 'movement' as a whole was more driven by individual issues than by larger scale political ideologies. These issues ranged from sporting contacts with South Africa, to land rights for Maori, to opposing a foreign military presence in New Zealand. Each issue had its own body of associated print, whether it was internationally sourced or locally produced by individuals and political groups, either way the Resistance Bookshops were spaces in which this material could be circulated. The following section gives an overview of the kinds of radical campaigns which were active during the 1970s. Some of these campaigns had a regional intensity to them, for example Nga Tamatoa and the Polynesian Panthers were concentrated predominantly in Auckland, while the anti-bases campaign was based largely in Christchurch. The regionalism had an impact on how connected each Resistance Bookshop was to a particular campaign and while many of these 
campaigns may have occurred quite separately to the bookshops, it is important to reiterate that the material that the bookshops stocked aided the movements in the wider purpose of 'consciousness-raising'.

The issue of sporting contacts with South Africa became an important part of radical politics from the late 1960s. In July 1969, HART, led by Trevor Richards, was established and the group ultimately became a key group in the campaign to end New Zealand's sporting contacts with apartheid South Africa. The first HART meeting was held in Auckland and brought together representatives from organisations including Citizens Association for Racial Equality (CARE), New Zealand University Students Association (NZUSA), Maori Organisation on Human Rights (MOOHR) and Socialist Forum. ${ }^{30}$ The meeting publicly denounced the proposed 1970 All Black tour of South Africa and resolved that the group would establish itself a base throughout the country. In the years following, HART organised demonstrations around the country opposing proposed tours. The PYM was also involved in anti-tour protest. In 1970 the Christchurch PYM organised "marches, pickets, street theatre, paint ups and cutting down the goal posts at Lancaster Park". ${ }^{31}$ The anti-tour movement achieved a small victory in 1973 when the Labour government stopped the proposed Springbok tour. Opposing sporting contact with South Africa was an important way to assert that New Zealand did not condone the racist policies of the South African government. However, National leader Robert Muldoon, elected Prime Minister in 1975, argued that the sport and politics were separate issues and condoned sporting contact between the two counties. The politics behind the anti-apartheid movement were highly visible on the shelves in the Resistance Bookshops: HART News and its successor Amandla were sold, books on apartheid were stocked, while the people involved with the shops were certainly also mobilising against sporting contacts. This was a campaign that would continue to be an important issue for protesters well after the Resistance Bookshops closed.

\footnotetext{
${ }^{30}$ Richards, p.44.

${ }^{31}$ Horton, p.33.
} 
The anti-base movement or Campaign Against Foreign Military Activities in New Zealand (CAFMANZ) was a movement that was driven by a specific issue. ${ }^{32}$ Figure 4

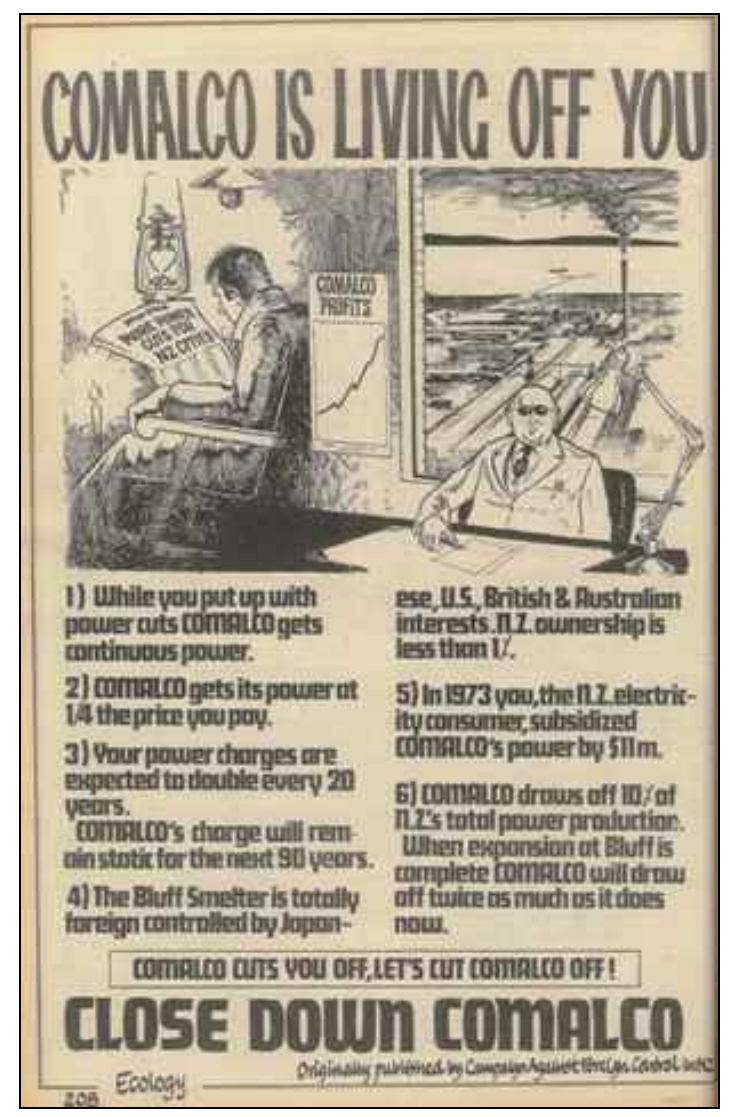

Figure 4 - Leaflet produced by CAFCNZ, illustration by Ron Currie, reproduced in The $2^{\text {nd }} \mathrm{New}$ Zealand Whole Earth Catalogue, 1975, p.208.

is an example of the type of leaflet produced by CAFCNZ. The campaign was mainly centred in Christchurch and included members who had also been involved with the PYM including Tony Currie, Murray Horton, Bill Rosenberg and Christine Bird, all of whom went on to become involved with the Resistance Bookshop in Christchurch. An 'emergency' edition of Canta was produced on the issue of the United States Navy's plans to erect an Omega low frequency radio transmitter which would enable ships and aircrafts to detect their exact position at the Operation Deepfreeze base at Christchurch Airport. ${ }^{33} 72,000$ copies of this issue were circulated throughout the country and it played a key part in encouraging over 800 students to participate when

\footnotetext{
32 The group's name went through several changes: CAFMANZ - Campaign Against Foreign Military Activities in New Zealand (1969-1975); CAFCINZ - Campaign Against Foreign Control in New Zealand (1975-late 1970s); CAFCA - Campaign Against Foreign Control in Aotearoa (Late 1970spresent).

${ }^{33}$ Canta, University of Canterbury, Vol.38, No.9; Owen Wilkes, Protest: Demonstrations Against The American Military Presence In New Zealand: Omega 1968, Woodbourne 1970, Mount John 1972, Harewood/Weedons 1973, Wellington, 1973, p.8.
} 
the first demonstration was held in June $1968 .{ }^{34}$ Owen Wilkes, a major figure in the anti-base campaign and who was involved with setting up Resistance in Christchurch, suggested that the Omega demonstration received so much attention was because "it was simply that this was the first time that New Zealanders were faced with a direct, immediate, unpleasant consequence of alliance with America". ${ }^{35}$ For radical protesters who were already concerned with the activities of the American military around the world, the expansion of surveillance equipment into New Zealand generated major concern.

During the early 1970s, the anti-base campaign grew and several other high profile demonstrations took place during this period. In January 1970, the Woodbourne demonstration brought 350 protesters to the RNZAF Base near Blenheim; protesters came from North Island as well as Christchurch. ${ }^{36}$ The peaceful protest was held to draw attention to the presence of the United States military on the base. In March 1972 a demonstration was held at Mount John, near Lake Tekapo, after information was obtained showing that the site was being used to gather data for a US antisatellite nuclear weapon system. ${ }^{37}$ Around 300 people converged on Mount John, an action which soon descended into chaos when the large police presence attempted to disperse the group. It was reported that police had assaulted protesters and also allowed police dogs to attack unarmed participants. Richard Suggate from the Resistance Bookshop in Wellington sustained a dog bite, subsequently becoming "the hero/martyr of the evening". ${ }^{38}$ The demonstration attracted sensationalist coverage from the media and police dogs were not used against demonstrators again. ${ }^{39}$ In March 1973 the Harewood/Weedons demonstrations were held, roughly 400 people marched to the US Navy base at Harewood to oppose the military activities on the base. Again there was a large police presence, 300 officers broke up the demonstration and eight people were arrested. The issues together students, peace activists, trade unionists and more radical protesters like those who had been associated with the PYM. These three

\footnotetext{
${ }^{34}$ Locke, p.262; Wilkes, p.7.

${ }^{35}$ Wilkes, p.16.

${ }^{36}$ Locke, p. 269.

${ }^{37}$ ibid., p. 272.

${ }^{38}$ Wilkes, p.39; Bruce Wallace, 'It's a Dog's Life at a Demonstration', New Zealand Listener, Vol.69, 24 April 1972, pp.8-9. For further discussion about the policing of demonstrations during this period see Susan Butterworth, More Than Law and Order: Policing a Changing Society 1945-92, Dunedin, 2005.

${ }^{39}$ Locke, p. 278.
} 
key protests cemented the place that the anti-base campaign had within Christchurch and the campaign continued to be a major focus for those involved with the Resistance Bookshop. CAFMANZ met at the action centre, demonstrations were planned there, placards painted and leaflets printed. This was one of the few instances where the Resistance Bookshop was literally at the centre of radical activity in the city, which was able to occur because the individuals running the bookshop were also heavily involved with CAFMANZ.

The environmental movement was a movement which grew largely from the public response to specific environmental issues. From the 1960s there was a growing awareness about issues of ecological concern in New Zealand. Commencing with the Save Manapouri Campaign which began to gain momentum in 1969, through to the campaign to conserve West Coast beech trees and the attempts to ban nuclear testing in the Pacific in the 1970s, these environmental issues and many others generated widespread support from a range of New Zealanders. These issues showed that environmental concerns were not merely radical issues, but rather they were becoming increasingly important within New Zealand politics. Malcolm Templeton has suggested that many of the supporters of the CND were likely to be the same people who were involved with the anti-Vietnam War and anti-apartheid protest in the late 1960s, engaging in direct action rather than "mere letter writing". ${ }^{40}$ Campaigns ranged from traditional parliamentary lobbying through to more radical forms of direct action. The Save Manapouri campaign organised a petition in 1970 to highlight public opposition to the plan, while on the other end of the spectrum, activists who opposed the logging of totara in Pureroa Forest took to protesting from the tops of trees in $1977 .{ }^{41}$

Groups like Ecology Action, the Native Forest Action Council and local chapters of international groups like Friends of the Earth were formed in the 1970s and lobbied for environmental concerns around mining, forestry and energy. Conservation also entered the agenda of parliamentary politics with the Labour Party even utilising the growing concerns about environmental issues for their 1972 election campaign,

\footnotetext{
${ }^{40}$ Malcolm Templeton, Standing Upright Here: New Zealand in the Nuclear Age 1945-1990, Wellington, 2006, p.135.

${ }^{41}$ For more information about Manapouri and Pureora see Young, 2004.
} 
announcing that it was "Preserving Time, a time to preserve what we have, while we still have it". ${ }^{42}$ The Values Party, which had environmental issues high on its agenda, was set up in 1972. For a time the Values Party was able to capture the support of voters disillusioned with the two major parties and in 1975 gained 5.2 per cent of the total national vote. ${ }^{43}$ However, there was little contact between Resistance and the Values Party. Even though environmental campaigns were of concern to people involved with Resistance, many political people regarded the Values Party as a middle-class lobby group, with little connection with the working class, Maori or radical activists. Peter Lusk, who stood for the Values Party in the 1972 election, and was perhaps somewhat disillusioned with his experience, wrote in the Counter Culture Free Press (CCFP) that the "Values Party is a party that is afraid of politics", emphasising that the party had no ideological base and was detached from grassroots political activity. ${ }^{44}$

To argue that the movement stemmed from particular issues rather than a conceptual basis is not to lessen the role that print had in raising consciousness about conservation and environment issues. There were texts like Rachel Carson's Silent Spring which had an important role in the dissemination of ideas and raising awareness about environmental issues. ${ }^{45}$ Environmental texts were stocked by the Resistance Bookshops covering issues including pollution and nuclear testing, through to local publications like New Zealand Environment published by the Chippenham Community in Christchurch. The consumption of these texts would have undoubtedly increased with the growing awareness about environmental concerns; equally print had an important role in educating people and possibly changing their views about consumption, waste and the need for 'preservation'.

For a time, opposition to the Vietnam War was the overriding issue that united New Zealand's protest culture. While this was an issue that all people on the left seemed to support, it did not have a wider social or political agenda. Further, the anti-war

\footnotetext{
${ }^{42}$ Quoted from a Labour Party advertisement from the 1972 Election, reproduced in Les Cleveland, The Politics of Utopia: New Zealand and its Government, Wellington, 1979, p.30.

${ }^{43}$ Stephen Rainbow, 'The Unrealised Potential of Green Politics: A study of four green parties', Victoria University of Wellington, PhD Thesis, 1991, p.100.

${ }_{44}^{44}$ Peter Lusk, 'Alternative society: Where is the political arm?', Counter Culture Free Press, No.5, August 1973, p.13.

${ }^{45}$ Rachel Carson, Silent Spring, London, 1962.
} 
movement was not always inclusive and for many women it highlighted that the inequalities that existed within wider society were also very much present within radical politics. This was just one stimulus for the emergence of a women's movement, which began to lobby for women's rights as a separate political issue within the 'radical space' of the time. Barbara Mountier, who was a member of the Christchurch $\mathrm{CoV}$, has suggested that "the anti-war movement contributed indirectly to a broader 'climate' of change in which women were better able to challenge accepted orthodoxies". ${ }^{46}$ The first public expression of the women's movement came in 1969 when Janet Bogle attempted to discuss women's liberation at the Radical Activists Conference in Dunedin. ${ }^{47}$ The male-dominated radical left who were attending the conference were dismissive of the notion of women's liberation as an important political issue and as a result a separate movement began to evolve. Groups such as the Wellington Women's Liberation Front and Auckland Women's Liberation Front were formed in 1970 and initially comprised largely of women who had also been involved in other left-wing political organisations. This separate political momentum was supported by women's groups which dealt specifically with issues affecting women. These groups also published their own magazines and newsletters, an example is shown in figure 5. Women's resource centres, health centres, refuges and bookshops were also established as a part of the wider attempt by women to create spaces specifically designated for women.

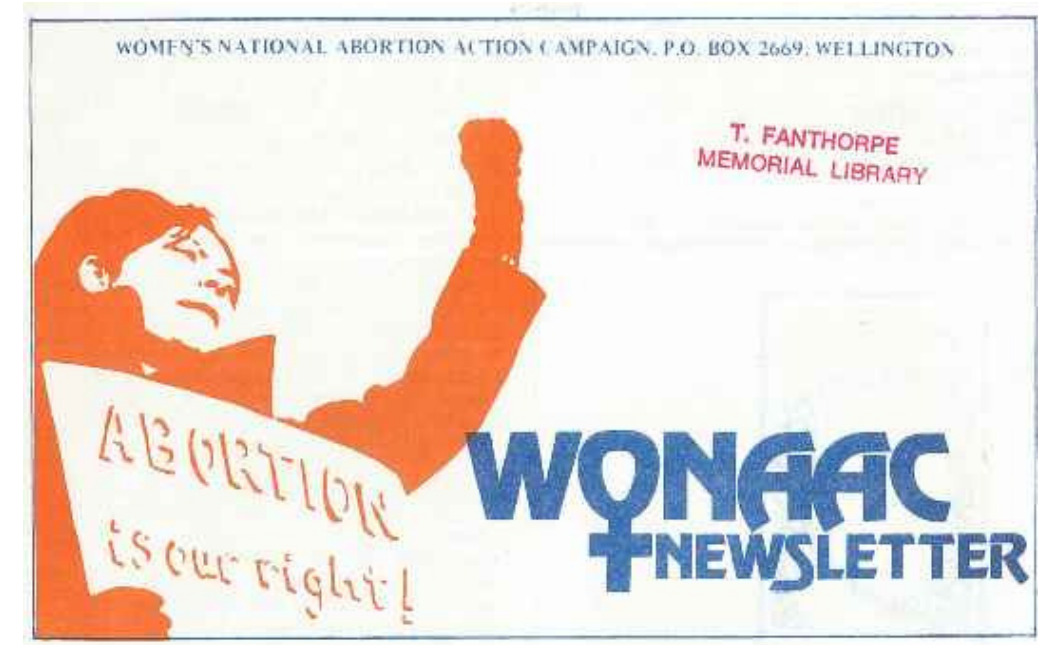

Figure 5 - Women's groups like WONAAC produced their own newsletters, 1975, TFML, Box 3.

\footnotetext{
${ }^{46}$ Barbara Mountier interviewed by Megan Cook, February 1996, Roberto Rabel and Megan Cook, 'Women and the Anti-Vietnam War Movement in New Zealand, Oral History in New Zealand, Vol. 10, 1998, pp.3-4.

${ }^{47}$ Dann, p.3.
} 
Grace Millar has argued that ideas stemming from books like Germaine Greer's The Female Eunuch and Betty Friedan's The Feminine Mystique played an important role in shaping the feminist movement in New Zealand. ${ }^{48}$ Millar quotes two women who emphasise the role that these texts had in opening their eyes to women's liberation. ${ }^{49}$ The Resistance Bookshops stocked texts addressing gender inequality and feminism as the movement was a very active part of the wider radical space of the 1970s. However, the print needs of women were not being met and independent women's bookshops were established towards the end of the 1970s, which will be explored further in chapter three. The women's movement was not always completely separate from other political groups, for example a group called Radical Feminists used the Resistance Bookshop's meeting space in Christchurch, a space which was also used by CAFMANZ, Gay Liberation Front (GLF) and Tenants Protection Association (TPA). ${ }^{50}$ Issues raised by women about their role within radical groups involving both men and women were issues that were not necessarily absent from the running of the Resistance Bookshops. The role of women within the bookshops will be explored further in chapter two.

The Gay Liberation movement came to the fore in 1972, with the GLF declaring its purpose being to remove "all the discrimination, prejudice and injustice that is directed at homosexual men and women". ${ }^{51}$ Laurie Guy has noted that "when gay liberation sprang up in New Zealand, it immediately drew a connection between its aims and those of black and women's liberation. New Zealand gay liberation activists studied the approaches and outcomes of the black and feminist movements". ${ }^{52}$ Gay women had been the first group to organise separately within the women's movement and they also established themselves independently within the gay liberation movement. Many lesbians had been involved with the Gay Liberation Front, which had formed in 1972, but left after it became clear that the group was dominated by males. Consequently Sisters for Homophile Equality (SHE) was formed in Wellington and Christchurch in 1973. Tony Currie of the Christchurch Resistance Bookshop recalled that "the gay movement broke up before our eyes, on the seats of the

\footnotetext{
${ }^{48}$ Millar, p.7; Betty Friedan, The Feminine Mystique, New York, 1963; Germaine Greer, The Female Eunuch, London, 1970.

${ }^{49}$ Millar, p.7.

${ }^{50}$ Tony Currie, correspondence 4 February 2007.

51 'Gay Liberation', The First NZWEC, p.241.

${ }^{52}$ Guy, p.92.
} 
Resistance "Action Centre" when gay men wolf whistled and teased the women present and drove them to form SHE". ${ }^{53}$ Sexuality was a topic that was found on the shelves of the bookshops, however, it was very much a minor area within the types of books stocked as a whole. The gay liberation movement continued to build momentum during the 1970s, lobbying to decriminalise sexual relations between men of consensual age and to end the discrimination of individuals on grounds of sexuality. ${ }^{54}$

The two political groups that the Resistance Bookshops had the least amount of contact with were Nga Tamatoa and the Polynesian Panther Party (PPP). Both groups were very politically active during the 1970 s and both represented the radical face of broader movements to challenge institutional racism and the empowerment of Maori and Pacific peoples. Nga Tamatoa marked the beginning of a new phase of Maori activism. In 1970 a group of young, urban and university-educated Maori formed the group, which aimed to challenge Maori inequality and affirm the role and importance of Maori culture in New Zealand. Nga Tamatoa became the public face of the radical 'Maori Renaissance', protesting at Waitangi on Waitangi Day, petitioning the government to allow Maori to be taught in schools and monitoring the courts, giving legal aid to Maori. The group initially used rhetoric stemming from the Black Power movement in the United States, an influence that the PPP would also draw from. ${ }^{55}$

The PPP formed in June 1971, establishing their headquarters in Ponsonby, an inner city suburb in Auckland that housed a large number of Pacific Island migrants. Chapters were also set up in South Auckland, Christchurch, Dunedin and in Sydney. ${ }^{56}$ The group was set up to support Pacific peoples and as well as actively opposing the discrimination that Pacific peoples faced, they also organised a number of community services like prison visits, a homework centre and provided tenancy support and legal advice. There was a strong link between Nga Tamatoa and the PPP. There was an acknowledgement early on that Maori were also marginalised people and the two

\footnotetext{
${ }^{53}$ Tony Currie, correspondence 4 February 2007.

${ }^{54}$ Decriminalisation was achieved under the Homosexual Law Reform Bill passed on 9 July 1986.

${ }^{55}$ Evan S. Te Ahu Poata-Smith, 'He Pokeke Uenuku I Tu Ai: The Evolution of Contemporary Maori protest', in Paul Spoonley, Cluny Macpherson and David Pearson (eds), Nga Patai: Racism and Ethnic Relations in Aotearoa/New Zealand, Palmerston North, 1996, p.102. Also see Aroha Harris, Hikoi: Forty Years of Maori Protest, Wellington, 2004.

${ }^{56}$ Anae, p.58.
} 
groups came together in March 1972 to form a "loose Polynesian Front". ${ }^{57}$ This joint effort meant that the PPP supported Nga Tamatoa in their attempts to promote the Maori language and this was reciprocated through Nga Tamatoa's support for the Police Investigation Group (PIG), a group organised by the PPP that monitored the seemingly unjust tactics of the police force against Pacific peoples. In terms of their association with the Resistance Bookshops, Currie of Christchurch Resistance recalled that Nga Tamatoa did not meet at the shop, but they were supporters of it. ${ }^{58}$ While Nga Tamatoa and the PPP may have used the Resistance Bookshops to acquire books, their relationship with the bookshops does not seem to have extended much beyond this. While the shops stocked both groups' newsletters, neither group ever used Resistance's meeting space. This limited interaction between the groups and the bookshops may have occurred because those involved with the bookshops were largely Pakeha or it may have been merely because both Nga Tamatoa and the PPP already had organising bases established.

The People's Union (PU) in Ponsonby was a space that was more closely associated with Nga Tamatoa and the PPP. It was concerned with "supporting the interests of working people", especially supporting the large number of low income and largely Pacific population in the area. ${ }^{59}$ The PU's front window is shown in figure 6 . The PU used community-based programmes to help create solidarity between political groups but also facilitated services like a food cooperative and running prison visits to Paremoremo to support the community. There were links between the PU and Resistance in Auckland, some of the individuals who had been involved in Resistance earlier went on to become involved with the PU. Both centres offered similar services but the PU was more closely connected with their community. This may have occurred because while the PU was political, it was not so overtly radical, which meant that it was more accessible to the community that it aimed to support. Between 1972 and 1979, when the centre closed, the PU was able to effectively work within the community, providing programmes and also participating in direct action around issues like dawn raids, rent protection and abortion. For a time the centre established

\footnotetext{
${ }^{57}$ ibid., p.8.

${ }^{58}$ Tony Currie, correspondence 4 February 2007.

59 'Direct Action in Local Struggles - Report on P.U. Programmes', People's Union: Community Information Service, No. 22, April 1979, p.10.
} 
itself as a valuable place within the community, this was a position that Resistance in Auckland had struggled to sustain.

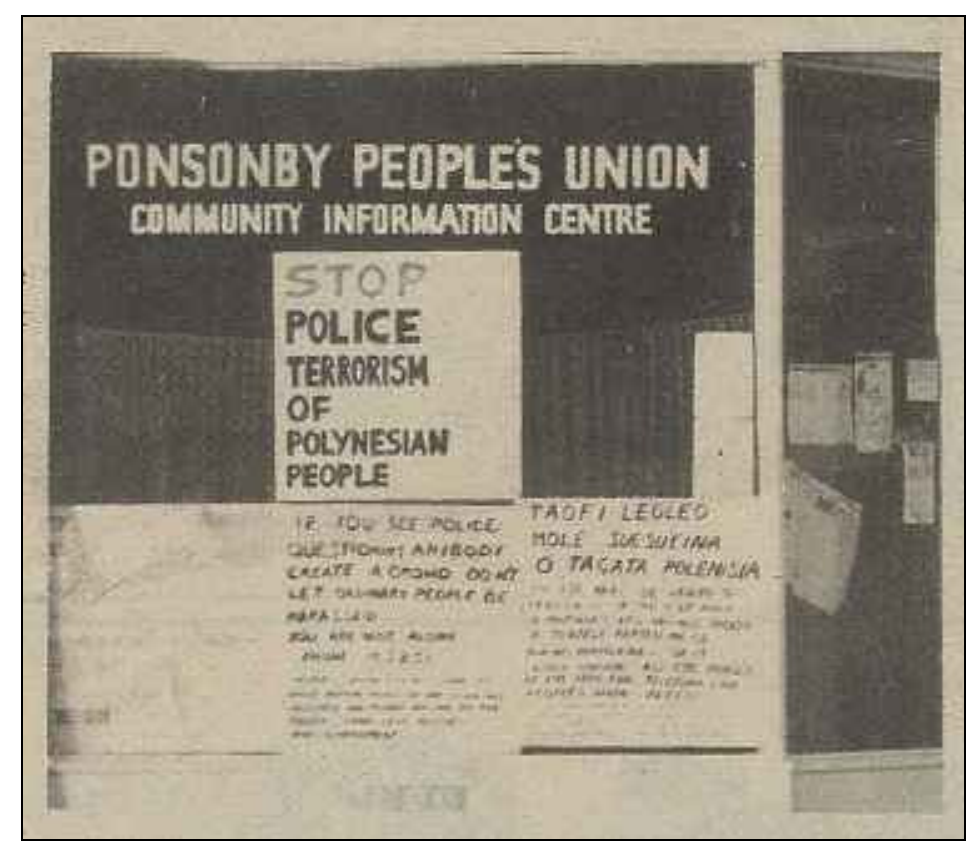

Figure 6 - Front of the People's Union in Ponsonby, People's Union: Community Information Service, No. 22, April 1979, p.16.

The 'radical space' of the late 1960s to the mid 1970s was made up of more than just a series of single issue campaigns; it also included a counterculture movement which grew simultaneously to the political activity from the late 1960s. The term represented a rejection of conventional culture and was encapsulated by a series of cultural and lifestyle based interests. Many young people embraced notions of antiauthoritarianism and sought 'liberation' from the constraints of established values and conventions. The counterculture was not a social movement, as it did not have a singular aim or direction. Rather, it was a fluid collection of ideas, values and tendencies, it was anarchic and is only definable because there were some aspects that were common internationally. ${ }^{60}$ Essentially the counterculture was about change at a personal level; it was considered political to grow one's hair or listen to a particular type of music. People challenged societal conventions in a series of ways, the most visible being by abandoning conventional notions of dress and grooming. Hair was grown long by men and women, some people wore bright coloured, paisley and

\footnotetext{
${ }^{60}$ Peter Braunstein and Michael William Doyle (eds), Imagine Nation: The American Counterculture of the 1960s and 1970s, New York, 2002, p.10.
} 
embroidered clothing was worn and in many some cases clothes were shed completely. New ways of living were pursued by some; this could include communalism, challenging sexual boundaries and conventions, vegetarianism, experimentation with drugs and adopting new forms of spirituality. Many of those embracing the countercultural lifestyles did not necessarily adopt all these elements, for example drug use was not mandatory and in many cases it became a dividing issue within political groups. Many of these aspects originated in the United States and became the prevailing expressions of the counterculture in the Western world. The counterculture was reflected in a huge number of print titles and for the Resistance Bookshops, these popular titles became very important because they were a major source of income for the shops.

While the counterculture was viewed by some to be largely apolitical, underground New Zealand publisher Malcolm Gramaphone argued conversely that "dropping out of the system...is the most effective way to influence and ultimately destroy the Establishment". ${ }^{61}$ The alternative lifestyle movement, which embraced principles of getting 'back to nature' and communal living, became closely aligned with the counterculture. ${ }^{62}$ The women's movement's challenge that the 'personal is political', spread to other social movements, by rejecting conventional living practices the alternative lifestyle movement showed that personal and lifestyle issues were also political issues. Living communally, working towards self-sufficiency, taking up alternative forms of medicine and education represented the holistic nature of the societal change that was being promoted. Communities like James K. Baxter's at Jerusalem became the focus of sensationalist media headlines and gradually entered the realm of parliamentary politics through the establishment of the ohu scheme in 1973. Alternative lifestyles generated much interest, particularly in the publishing world. Hundreds of 'do-it-yourself' titles were produced, with the First New Zealand Whole Earth Catalogue (NZWEC) going on to sell approximately 20,000 copies. ${ }^{63}$ There was a large interest in countercultural and alternative lifestyle titles and even

\footnotetext{
${ }^{61}$ Counter Culture Free Press, No.1, c.1972, page unnumbered.

${ }^{62}$ See Megan Simpson, 'Escaping the Isolated Suburbia Trip: Exploring the alternative lifestyle movement in New Zealand in the 1970s', BA (Hons) Research Essay in History, Victoria University of Wellington, 2005.

${ }^{63}$ Tim Jones, A Hard-Won Freedom: Alternative Communities in New Zealand, Auckland, 1975, p.154.
} 
though the ideas contained in these books were only taken up by a small number of people, this does not lessen the fact that there was a great deal of interest in alternative ways of life. By engaging with these books, people were exploring ideas that were political and challenging to the conventional societal model.

To adopt an 'alternative' or countercultural lifestyle was seen as a radical departure from the constraints of orthodox ways of living. One of the ways that a person could challenge this was by altering one's consciousness through drug use. People experimented with LSD and marijuana as a means to have psychedelic experiences but also for many, drug use was also a deeply radical act. There were differing attitudes towards drug use within political groups, the PYM in Auckland banned its members from taking drugs, while the PYM in Christchurch did not support drug use but also did not exclude those wanting to use drugs. ${ }^{64}$ Likewise, the PYM in Wellington stated in the PYM Rabble that "PYM attitudes are, on the whole, remarkably similar to those of the general public" and criticised the scare tactics of the mainstream press, connecting leftist politics with drug use. ${ }^{65}$ At Resistance in Auckland, there was a division among the early group living at the shop over drug use which resulted in part of the group leaving to set up their own organising base in Ponsonby. ${ }^{66}$ The group that left were very politically active but they were also interested in countercultural pursuits, like taking drugs and music; this caused tension with those people who had a more "pure" view of radical politics. ${ }^{67}$ The views of the two sides were significantly different, while one side advocated expanding one's consciousness to enable social change, the other placed prime importance on rallying politically and campaigning for social and political change. This was an unresolvable division within the 'movement'.

To some, drug use was an apolitical pursuit, an artificial state that did little to bring about political change. This concern about the apoliticism of the counterculture soon evolved to focus on the new spiritual movements that some youth had become drawn to. This movement towards mystic and eastern religions also surfaced in the United States, United Kingdom and Australia and presented itself within the teachings of

\footnotetext{
${ }^{64}$ PYM Rebel, Issue 27, 1971, p.3; Campbell, 1991.

65 'Drugs, Politics and the PYM', PYM Rabble, No.3, August 1970, p.10.

${ }^{66}$ Sue Bradford, interviewed 27 September 2006.

${ }^{67}$ ibid.
} 
Indian and Buddhist spirituality, particularly through the Divine Light Mission and the Hare Krishnas. ${ }^{68}$ Denis Cooney, who had been a shareholder and shop manager for the Auckland Resistance Bookshop had been very politically active before becoming a member of the Divine Light Mission, a non-denominational group that embraced principles of love, peace and tranquillity. ${ }^{69}$ After leaving Resistance, Earwig reported that someone at Resistance refused Cooney the use of the Gestetner (a duplicating machine) stating that "we're competing against you to win the minds of youth". Figure 7 shows the headline for this article. ${ }^{70}$ Earwig presented a scathing portrayal of Resistance, claiming that "it suffered from all the ego trips, intolerance, stupidity, plots and bad vibes which it felt were the evil things in honky society". ${ }^{71}$ The case of Cooney was used to argue that many people, through their involvement with Resistance, wanted to use the space to achieve a level of peace and social change, however Resistance seemed to have little success in actually achieving this which led to people exploring spiritual avenues.

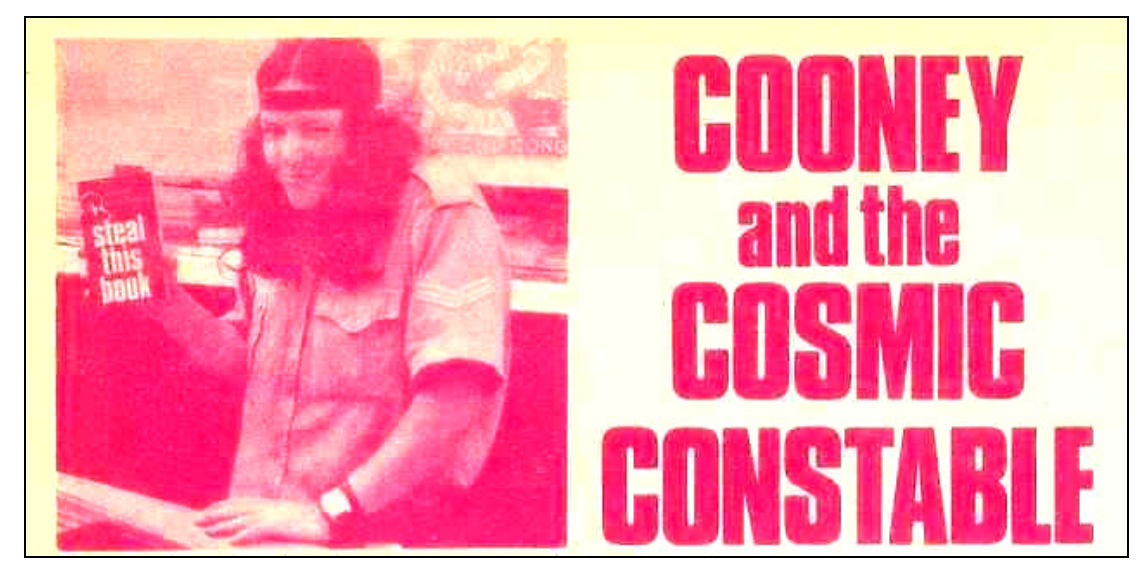

Figure 7 - Dennis Cooney holding a copy of Abbie Hoffman's Steal This Book, headline from Earwig $81 \frac{1}{2}$, c. 1972 , p. 35 .

The political actions and the attitudes of those associated with the 'movement' endure within the cultural artefacts that remain from this period. Through the underground magazines, newsletters, cartoons and songs, one gains an indication of the type of ideas that were prevalent within the 'radical space' of the 1970s. These 'authentic'

\footnotetext{
${ }^{68}$ See Dennis Cooney, 'Divine Light', The $2^{\text {nd }}$ NZWEC, edited by Dennis List and Alister Taylor, Martinborough, 1975, pp.115-6 and Robert S. Ellwood, Islands of the Dawn: The Story of Alternative Spirituality in New Zealand, Honolulu, 1993.

69 'Cooney and the Cosmic Constable', Earwig, Issue 81/2, c.1973, p.35.

${ }^{70}$ ibid.

${ }^{71}$ ibid.
} 
expressions originally came from a grassroots level, whether included in the pages of Cock or in a BLERTA show; the arts were a place where creativity and politics could meet. ${ }^{72}$ The two most accessible cultural expressions of the counterculture were print and music, and both became the most widely consumable items of the counterculture 'industry'. While the essence of the counterculture seemed to stand in opposition to business interests, the reality was that it generated huge industry around it. From books, to clothing, films and music, these cultural expressions soon became influenced by commercial enterprise. While both Cock and BLERTA could not be accused of being commercially motivated, many other individuals who profited from the counterculture were accused of being 'hippie capitalists'. Publisher Alister Taylor and the lesser known Wellington importers of 'hippie' artefacts, the Merchant Adventurers of Narnia, were both examples of this type of countercultural commercialism. Hippie capitalism had originally flourished in the United States, producing magazines, books, clothing and posters that represented the beliefs and values of the movement. ${ }^{73}$ Much of the print generated by this industry was very popular, and many of the well known titles were sold at Resistance.

Within the counterculture and political movements there was a tension that existed between those who were economically benefiting from the counterculture and those who opposed the capitalist system. Resistance somewhat straddled the two points of view. They were a commercial operation, they sold books at the recommended retail price, they occasionally paid for advertising in mainstream publications like the Listener and they were required to pay for the rent of the premises. On the other hand, they were a collective and voluntary operation that was concerned with distributing books not gaining profits. This paradox was not easy to resolve, and the two positions often coexisted within the pages of the bookshop's own publications. On one instance, a book was reviewed in a newsletter that discussed the propaganda of industry and concluded with the statement that "Capitalism is the enemy. Understand It. Organise to destroy it" ${ }^{74}$ The interesting contradiction was that while encouraging the abolition

\footnotetext{
${ }^{72}$ BLERTA: Bruno Lawrence Electric Revelation and Travelling Apparition, formed in 1971 and comprised of a travelling troop of musicians which staged concerts, children's theatre and went on to achieve a Top 20 single in the national charts. See Dix, pp.121-8.

${ }^{73}$ Terry H. Anderson, 'The New American Revolution: the Movement and Business', in David Farber (ed), The Sixties: From Memory to History, Chapel Hill and London, 1994, p.193.

${ }^{74}$ Assistance, 30 January 1974, pp.3-4, TFML, Box 1, Folder 1.
} 
of capitalism, the purpose of the review was essentially to promote a book that they were selling.

The 'radical space' which emerged from the late 1960s in New Zealand was a combination of social and political movements, personal revolt and the emergence of cultural expressions, which represented the social upheaval of this period. The agenda of radical protesters included opposition to the Vietnam War and sporting contacts with South Africa, they resisted moves by the United States military to establish bases in New Zealand, and they opposed racism, sexism and worker exploitation. This atmosphere of radicalism was a major component in establishment of the Resistance Bookshops. Born out of the politicised subculture of youth frustrated with the 'Establishment' the bookshops aimed to draw on the impetus of the protest culture and establish themselves as 'radical spaces' in a physical sense, to foster progressive discussion and action. The desire for radical information combined with the aim to bring together political groups was the very basis for the shops and remained the core motivation throughout the years that the Resistance Bookshops operated. The political campaigns and counterculture while instrumental in the formation of the bookshops also contained the individuals which would form the shops' support base. It was a diverse group of individuals and as the following chapter will argue, the difficulties associated with running a cooperative existed despite the momentum and enthusiasm that this protest culture generated. Regardless of these difficulties, the Resistance Bookshops were an instrumental part of the 'radical space' of the 1970s' as their efforts to distribute political texts had a key role in consciousness raising and possibly in encouraging people to mobilise for political change. 


\section{Chapter Two \\ From the "bowels of the underground": An overview of the Resistance Bookshops ${ }^{1}$}

Opening in late 1969, the first Resistance Bookshop appeared in Queen Street, Auckland, and from the outset presented itself at the forefront of political activity in the city. It was a site to be used as an organising base, a place for education and as a means to unite the city's various political groups. The bookshop was run by a collective of mostly young workers and students stocking a wide range of publications from leftist doctrine to countercultural texts through to popular literature. Two further bookshops were opened in Wellington and Christchurch, entirely independent of each other but embracing similar ideas to the original shop in Auckland. Together these three bookshops or 'radical spaces' in a concrete sense, encouraged individuals to read political texts, to engage with the ideas being proposed and to participate in direct action. The following chapter will examine the histories of the three Resistance Bookshops, looking specifically at how they operated and their connection with the protest culture and political momentum of the 1970s.

The Resistance Bookshops, much like the PYM before them, were regionally autonomous groups; each location having their own members, aims, directions, associations with political groups, and distinctive character. However, while the Resistance Bookshops had a political purpose, they were not political organisations in themselves; they were "more a place where people who had left sympathies could look for information or have the information distributed through". ${ }^{2}$ The bookshops were participating in the radical political culture of the 1970s by stocking political and alternative texts, which explored ideas connected to the various political campaigns active in New Zealand. Aside from examining how the Resistance Bookshops operated, this activity will be the major focus for this chapter: by being an important source of political and alternative information, the Resistance Bookshops established themselves as an instrumental part of the culture of radical politics and protest.

\footnotetext{
${ }_{1}^{1}$ Advertisement for the Resistance Bookshop in Auckland, Earwig, Issue 3, c.1970, p.2.

${ }^{2}$ Richard Suggate, interviewed 20 August 2006.
} 
While the bookshops shared a name, this was not an indication that the Resistance Bookshops were a franchise or were part of a national organisation. Rather, the decision by the Wellington and Christchurch bookshops to take the same name as Auckland was most likely chosen as an act of solidarity, to display and signal to the public that the three spaces had similar aims and directions. In suggesting this, Marty Braithwaite, who was involved with Resistance in Christchurch, stressed that while there was no formal arrangement between the three shops, lots of the individuals knew each other and many of the broad aims were the same. ${ }^{3}$ Murray Horton, also of Christchurch, reinforced this notion of solidarity: "it was the same with the PYM...it was felt that there should be some sort of sense of a national movement but very much with local characteristics, and the same applied with Resistance Bookshops". ${ }^{4}$ While the bookshops were autonomous they did see themselves as being connected to a wider 'movement' and consequently chose a name that signalled this.

Resistance emerged during a period of increased political activity in New Zealand. The Resistance Bookshops were a manifestation of this protest culture and aimed to be a space that informed and supported radical activity. Members of various branches of the PYM were involved in the establishment of all three bookshops. For Wellington and Christchurch, the opening of the bookshops coincided with the winding down of PYM activity. Ex-members comment in the documentary Rebels in Retrospect that the Resistance Bookshops were just one of the political directions that PYM members gravitated towards. ${ }^{5}$ The Christchurch PYM reported that the bookshops were modelled on the Third World Bookshop on Goulburn Street in Sydney. ${ }^{6}$ The Sydney shop had opened in 1967 and also had a number of functions, with a bookshop, printery and a meeting and organising space for political actions all being housed in the same premises. ${ }^{7}$

The Resistance Bookshops were connected with the political activity in each city but this relationship was changeable and dynamic and each bookshop had varied success

\footnotetext{
${ }^{3}$ Marty Braithwaite, interviewed 20 August 2006.

${ }^{4}$ Murray Horton, interviewed 20 August 2006. Horton and Braithwaite were interviewed together.

${ }^{5}$ Russell Campbell, Rebels in Retrospect: The Political Memoirs of Some Members of Christchurch and Wellington PYM: in 19 parts, 74 Minutes, Vanguard Films, Wellington, 1991.

6 'The Morality of Ripping Off', Rag-Tag, Rabble-Rousing, Mickey Mouse Stuff, No.3, undated, p.3.

${ }^{7}$ John Percy, 'Youth in Revolt: the 60s and today', Green Left Weekly, No.329, 19 August 1998; available at http://www.greenleft.org.au/1998/329/20586; accessed 2 December 2006.
} 
in maintaining their relationship with leftist activities in each city. For Christchurch, the bookshop was at the centre of political activity in the city, organising demonstrations, bringing together the various groups of the city and distributing alternative or political information. But for Auckland and Wellington, the bookshops had the difficult task of bringing together leftist groups in larger cities, uniting elements that seemed to be much more staunchly sectarian than in Christchurch. The difficulties that each shop faced when interacting with political groups will be explored individually later in the chapter.

For those outside of protest circles, Resistance was a physical reminder of a movement whose presence was otherwise erratic. To the apathetic public and to the authorities, the protest movement was a series of demonstrations and disorder, represented by groups of unkempt young people. The Resistance Bookshops challenged this perception. They represented an 'organisation' that was run by the 'movement', an organisation that provided for the 'movement' and for a time they were an expression of the protest culture that was present in each of the main cities. Those involved with Auckland Resistance were aware that the shop was seen as being representative of the 'movement'. On his departure from Resistance in 1972, Pat Bolster produced a shop manual which contained very detailed instructions about the running and finances of the bookshop. In the manual he expressed the importance of the physical presence of the shop, claiming that it was "an 'Ad' for the movement...let us not re-inforce [sic] our detractors' comments by presenting [an] amateurish disorganised face to the world". ${ }^{8}$ This was an idea that was later picked up by HART, which encouraged protesters to attend a rally in neat clothing (no jeans were allowed) in order to challenge public perceptions about the type of person that was involved in anti-apartheid protest. ${ }^{9}$ Resistance also represented the 'constructive' side of protest. When questioned in an interview about the productive impact of activism, Tim Shadbolt noted that "protesters do spend a lot of their time doing other things, for example in Auckland we started a shop, now they are planning a day care

\footnotetext{
${ }^{8}$ This was obviously an important guide for the Wellington shop as well. The Wellington copy had the words "Not to be removed from the desk under any circumstances" scrawled across it. Pat Bolster, Resistance Shop Manual, Auckland, 1972, TFML, Box 1, Folder 1.

${ }^{9}$ Richards, p.139.
} 
centre". ${ }^{10}$ In this respect, the shop was an important expression of the 'movement' in Auckland because it suggested that protesters were involved with actually forging an alternative, rather than just attacking the 'Establishment' without proposing another option.

As a bookshop, Resistance supplied texts that were unavailable in mainstream stores; this material was often declared to be radical or subversive due to its unconventional or challenging content. The nature of the print stock was essential as it was hoped to serve the aims of the wider political movement and counterculture. Both the print that was being produced and the Resistance Bookshops were products of the radical space' of the 1970s. Therefore it was essential that the material that was being stocked was reflective of the type of politics and ideas that were being explored within radical political movements. In terms of what was sold, the bookshops stocked a range of political and countercultural material that had limited availability. Chain stores like Whitcombe and Tombs did stock some popular alternative publications like Bullshit and Jellybeans but they did not provide the 'serious' political texts important for educating those involved in the wider movement. For those types of texts, aside from Resistance, the 'Old Left' bookshops were the only providers of such material. But the Resistance Bookshops represented a type of leftist politics that was quite distinct from the 'Old Left' bookshops in Auckland and Christchurch. These bookshops tended to stock predominantly communist and socialist texts that presented the orthodox, Soviet line of revolutionary politics. These bookshops also operated at a distance from Resistance due to an ideological and generational divide.

A distinguishing aspect of the three Resistance Bookshops was that as well as being distributors of alternative material the bookshops were also producers of it. Those involved in the bookshops were often the same people producing, collating, designing and distributing material, from the larger scale publications like Ferret through to the more ephemeral print for handouts at demonstrations and meeting notices. Kozmik Krumbia, the printery at Christchurch Resistance Bookshop, produced this type of material, an example is shown in figure 8. Printing was done on the premises not because it was seen as a means to increase revenue, but for two quite separate reasons.

10 'Tim Shadbolt: High Priest of the Protest Movement', New Zealand Listener, Vol.66, 22 March 1971, pp.10-1. 
Firstly, commercial printers were costly and also cautious about printing politically and morally confronting material due to libel, sedition and indecency legislation. Printers could be charged for libel under the Defamation Act 1954 and those publishing material that "points out error or defects in Government" could even be charged with seditious offences under the Crimes Act 1961.11 The Indecent Publications Act 1963 also had implications for printers, who could commit an offence under the Act by printing a document that came under the Act's definition of indecency. ${ }^{12}$ Secondly, having printing equipment on site enabled political groups to control their own publishing. They were also able to function outside of normal, commercial channels and could charge at cost price, thus making self publishing a more affordable option.

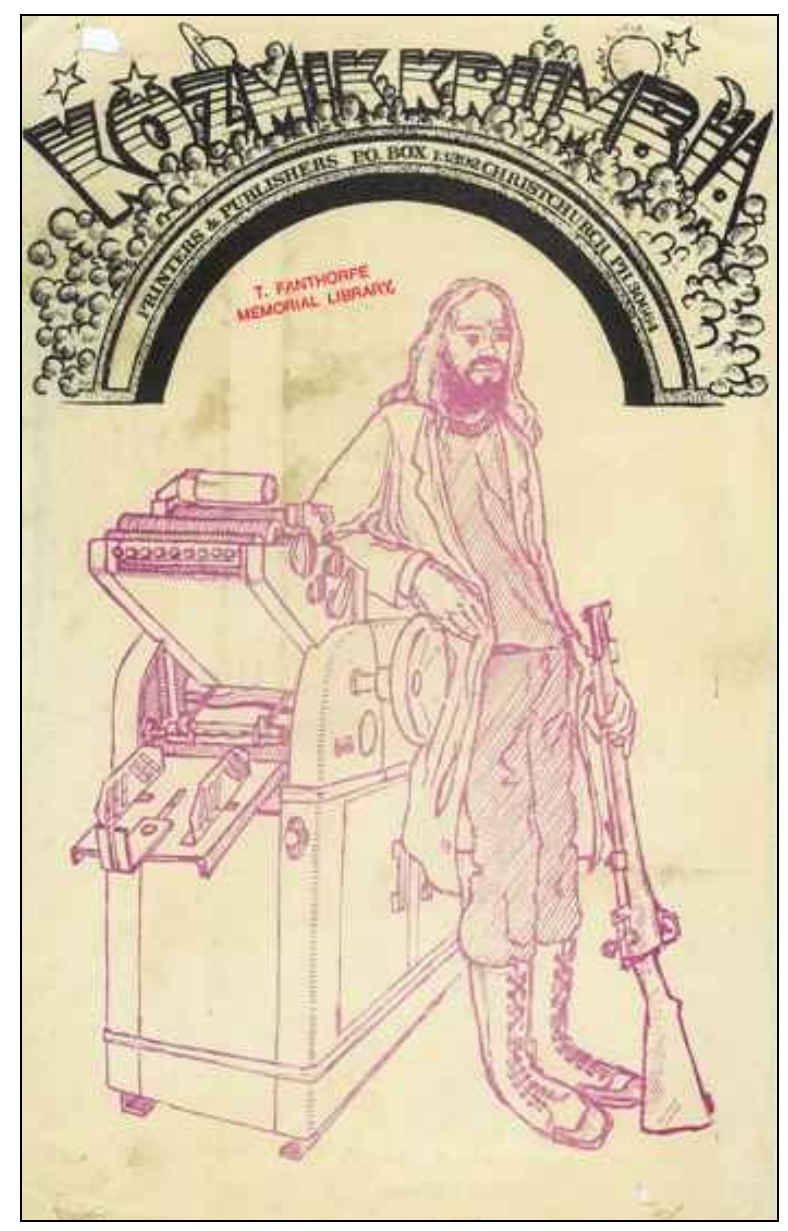

Figure 8 - The revolutionary and the printing press, an image produced by Kozmik Krumbia, c.1973, TFML, Box 1, Folder 4.

\footnotetext{
${ }^{11}$ Crimes Act 1961, 'Seditious Offences' s81(2)(a).

${ }^{12}$ Indecency was defined as "describing, depicting, expressing, or otherwise dealing with matters of sex, horror, crime, cruelty, or violence in a manner that is injurious to the public good." Indecent Publications Act 1963, s21(b), reproduced in Perry, 1980.
} 
While selling political texts was a core part of Resistance's purpose, the bookshops also provided a number of other facilities. Together, all three bookshops had printing equipment, meeting space, accommodation and a library. ${ }^{13}$ Christchurch and Auckland also ran food cooperatives. In addition, all three bookshops aimed to act as information centres, giving out 'crash pad' details and circulating flyers. While the bookshops all relied on the sale of books and magazines to keep afloat, they were more interested in encouraging participation in political activity. These overriding aspirations were never cemented by a shop manifesto or national programme for Resistance. Auckland shop secretary Pat Bolster included a list of aims in his shop manual but was careful to state that the aims had "never really been fully debated and codified" in any way. ${ }^{14}$ Despite not having an agreed direction, there was, at least initially, a general consensus about the purpose of the bookshops and each 'radical space' was able to operate without being tied to a set constitution.

The relationship that Resistance could maintain with political groups was important in sustaining the bookshop's relevance to movement activity in each city. The idea of being a space to bring together leftist groups was a central concept for each shop. This was also a key aim listed by Bolster in his shop manual, noting that as well as encouraging political groups to use the meeting space at Resistance, the bookshops should also aim to "try to unite students, workers, trots, Yippies, the Socialist Unity Party, the Progressive Youth Movement, Polynesian groups, high school groups and women's liberationists". ${ }^{15}$ Resistance in Christchurch, perhaps more so than the other two bookshops, succeeded in creating an inclusive space for radical and leftist groups and consequently became "a key part of the physical presence of the active left in Christchurch". ${ }^{16}$ This was reflected by the sheer number of groups included within the pages of its shop newsletters. Groups like CAFMANZ, HART, Sisters for Homophile Equality (SHE), Release All Vietnamese Prisoners of Conscience (RAVPOC), Radical Feminists, Tenants Protection Association (TPA) and Gay Liberation were all included and the newsletters gave details about times and venues for meetings and

\footnotetext{
${ }^{13}$ Wellington Resistance was not always able to offer these services at one time, it was dependent on the premises which it was located in and the level of support that the shop was generating.

${ }^{14}$ Bolster, p.6.

15 ibid.

${ }^{16}$ Horton interview.
} 
contact details. These newsletters demonstrate that the Action Centre genuinely acted as such and groups actually used Resistance as a place to meet and organise.

The Resistance Bookshops had some association with groups defined as 'Old Left'. In Christchurch, the CPNZ and the SUP regularly sent delegates to the shop's meetings and they would even "try to give some kind of political analysis of whatever decisions were being made", acting as "self-appointed advisers". ${ }^{17}$ This was particularly evident after the United States Consulate in Christchurch was set alight by activists in $1973 .{ }^{18}$ Members of both the CPNZ and the SUP were concerned by the radical and extreme actions that were being undertaken and attempted to steer Resistance members in a more moderate direction. ${ }^{19}$ In Wellington the SUP rented an office from the Resistance Bookshop and during 1975 they were located upstairs from the bookshop. Interviewees from both Christchurch and Wellington recalled that Auckland Resistance had close ties with the CPNZ, however, there is little confirmation of this found in the shop's newsletters. All three bookshops seem to have had limited contact with trade unions. The shops stocked labour related newsletters, pamphlets and leaflets but there is little mention of trade unions in the shops' own newsletters or correspondence. ${ }^{20}$ Those involved with Resistance would also have had been in contact with unions and 'Old Left' groups through protest activity. The 'Old Left' was a core part of those groups and individuals mobilising for causes like the anti-Vietnam War and anti-tour movements.

Due to their seemingly close relationships with a range of political groups and actions, the Resistance Bookshops came under police scrutiny. This police attention came in many forms, in some cases police would engage in 'friendly visits', where both uniformed and plain clothed police officers would come into the shop, examine stock or question the staff about future protest action. More seriously, the police raided the three bookshops on various occasions looking for obscene publications or drugs. For Cock editor Chris Wheeler, the actions of the police were seen as being part of the wider attempts by the 'Establishment' to restrict freedom of speech. In the last edition

\footnotetext{
${ }^{17}$ Tony Currie, correspondence 4 February 2007.

${ }^{18}$ The consulate fire will be discussed further on pages 91-2.

${ }^{19}$ Tony Currie, correspondence 4 February 2007.

${ }^{20}$ The TFML includes print produced by the New Zealand Tramways Union, the Wellington Unemployed Workers Union and the Federation of Workers.
} 
of Cock in an article on police and the 'Free Press', Wheeler included an overview of police pressure on Resistance and even reported that the Wellington police department had a memorandum entitled "Possible ways of closing down Resistance Bookshop". ${ }^{21}$ The memorandum was said to have been distributed in July 1973 and mapped out three grounds that the police could use to put pressure on the shop. Firstly it was reported that two secondary school students had used the shop as a meeting place to plan running away from home, secondly, the shop was allegedly used for drug dealing and thirdly, the bookshop was selling the controversial magazine Itch. $^{22}$ Collectively these were reason enough to warrant increased police interest. ${ }^{23}$

The bookshops were collectively owned and were run by volunteers and all three bookshops shared a collectivist ethos. The organisational structure demonstrated the groups' commitment to collectivism. Recruiting workers was an important aspect in running each bookshop, it was important for Resistance to emphasise that working within the collective environment of the bookshop was in itself a political act. While standing behind a counter or organising a roster may not have felt particularly radical, in reality it was an essential role in ensuring firstly, that the shop could survive, and secondly, that it could work towards its fundamental aims. Both customers and workers tended to be young, in their late teens to mid twenties. ${ }^{24}$ Depending on the structure of each shop, there were a number of roles which individuals could be responsible for. Each bookshop had a shop manager who oversaw the running of the shop, took responsibility for ordering books and paid invoices and other administrative tasks. Due to the shareholding structure of Auckland and Wellington, the shops also had to appoint a treasurer and secretary, both of which were unpaid positions.

The types of individuals involved with Resistance in each of the cities differed greatly; the bookshops in Auckland and Wellington were closely associated with the universities, while Christchurch was more connected with the young workers in the

\footnotetext{
21 'Of Libels and the Police Conspiracy Against the Free Press in NZ', Cock, Issue 17, August 1973, p.5.

${ }^{23}$ Each shop had quite different experiences with police surveillance and these will be discussed individually later in the chapter.

${ }^{24}$ There is not data that can quantify the age of Resistance's associates but photographs of those involved with the shops and the recollections of people involved support this.
} 
city. In Auckland the shop initially had close associations with the university; many individuals had been involved with the PYM or with AUSAPOCPAH. In the latter period workers consisted of a more diverse range of political affiliations and backgrounds. Wellington was also largely associated with the university, though many of those involved were also young, working-class individuals and the shop also had a strong contingent of ex-PYM members. Christchurch, more so than the other two bookshops, was quite independent of the university and was run predominantly by young workers, many of whom came out of the PYM. The progress of each shop was highly reliant on the level of support both in terms of people volunteering and the actual number of customers. For each shop the level of support was marked by a series of phases, from the enthusiasm and momentum of the early period through to the reduced support of later days. That decline impacted on the shops' income and also made encouraging people to help out even more difficult. The shops thrived when there were a lot of people using the space, but without this support the shops lost much of their vitality and people lost interest in being involved.

In terms of gender, there are marked similarities between the Resistance Bookshops and political groups of the same period. As with other organisations like HART and AUSAPOCPAH, the Resistance Bookshops tended to be run overwhelmingly by men. Sue Bradford recalled that at the time the Auckland shop was being set up, she was the only woman, living there with a dozen or so men. ${ }^{25}$ This gender imbalance may not have been as pronounced in Wellington and Christchurch but interviewees from both cities recalled that males dominated the collectives as a whole. ${ }^{26}$ Looking at the three shops together, during the eight years that the bookshops were open, there seem to have been only two female shop managers, Ruebena Paraha in Auckland in 1972 and Joy Young in Christchurch in 1975, both in the later period that the shops were operating. Those involved with the bookshops also tended to be Pakeha, however this is difficult to gauge and is based largely on identifying ethnicity by name only. While those involved may have been predominantly Pakeha, there were distinct attempts to connect Resistance with groups like Nga Tamatoa and the Polynesian Panthers. ${ }^{27}$ The bookshops distributed both groups' newsletters, included information about both

\footnotetext{
${ }^{25}$ Bradford interview.

${ }^{26}$ Braithwaite, Horton and Suggate interviews.

${ }^{27}$ See pages 36-7 for discussion of the relationship between the Resistance Bookshops and Nga Tamatoa and the Polynesian Panthers.
} 
groups in their own newsletters and Wellington Resistance even loaned the People's Union in Wellington $\$ 60$ to set up a space on Adelaide Road; this space also housed the Wellington headquarters of the Polynesian Panthers and thus created a connection between the two groups. ${ }^{28}$

The bookshops shared a name, but their independence from each other was also expressed by their own individual letterhead, each of which contained different logos and symbolism. All three logos are shown in figure 9. The logo selected by the Auckland shop was the universal symbol of resistance and solidarity, a clenched or raised fist. Wellington was the only shop not to use a symbolic design, instead using an illustration of the house that the shop occupied at 154 Willis Street. Christchurch used the highly symbolic logo of the eagle with a five point star. The eagle is generally a symbol of political might, while the five point star is an anarchist symbol, and is often seen on anarchist flags. Despite the independence of each shop, there was some interaction which came in the form of sharing stock and general correspondence which covered shop matters through to discussions about the shops' directions. Letters were sent between the three shops asking about stock, giving advice on ways to run the shops, and there were ideological debates and general discussions around political activity.

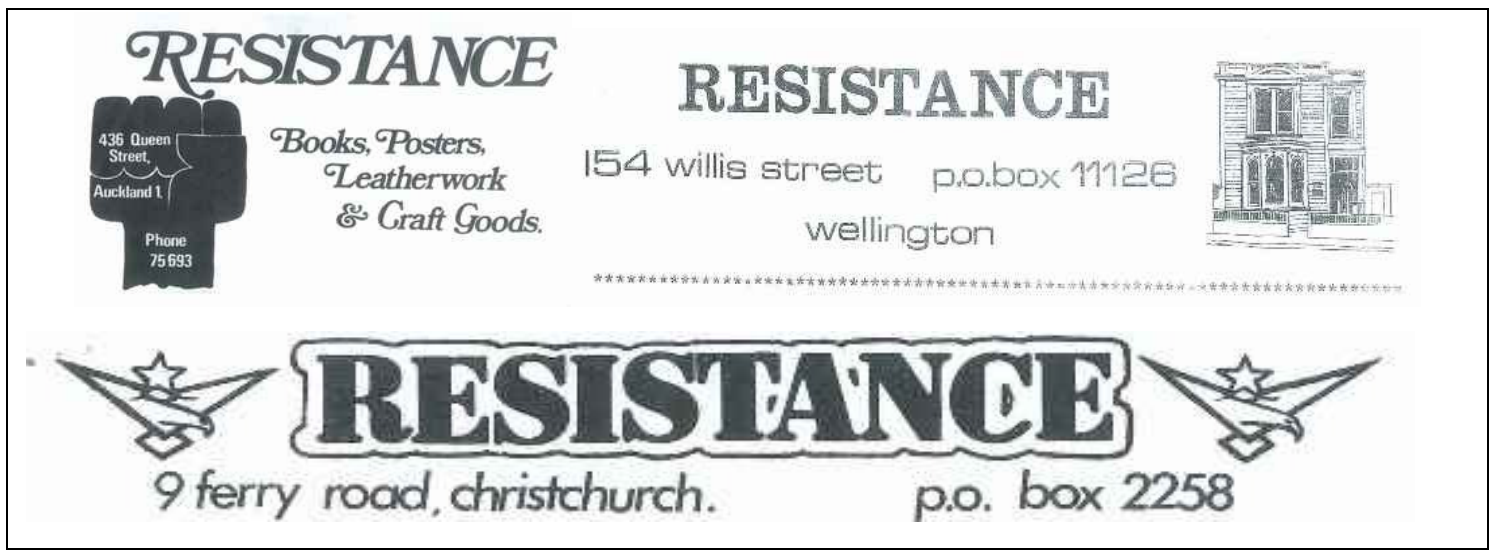

Figure 9- Resistance bookshops' logos and letterhead, Auckland: 1969, Wellington: 1971, Christchurch: 1972, TFML, Box 1, Folders 2 and 3.

Advertising also tended to be done on an individual basis, with the shops using underground magazines like Ferret and Earwig for promotion. On one occasion the

\footnotetext{
${ }^{28}$ Wellington Resistance Accounts Newsletter, c. September 1974, Eph-B-ROTH-Resistance, ATL, Wellington.
} 
three shops advertised together in the Listener, this included a brief list of the type of stock found at the three bookshops, shown in figure 10. This would have been an expensive form of advertising for Resistance and there is no information available about how the advertisement was paid for and whether it produced an improvement in customer levels for the three shops. Independently, Auckland Resistance also advertised its stock in association with Book Project, a New Zealand left wing book distributor; this advert included a lengthy list of the titles available and was also included in the Listener. $^{29}$

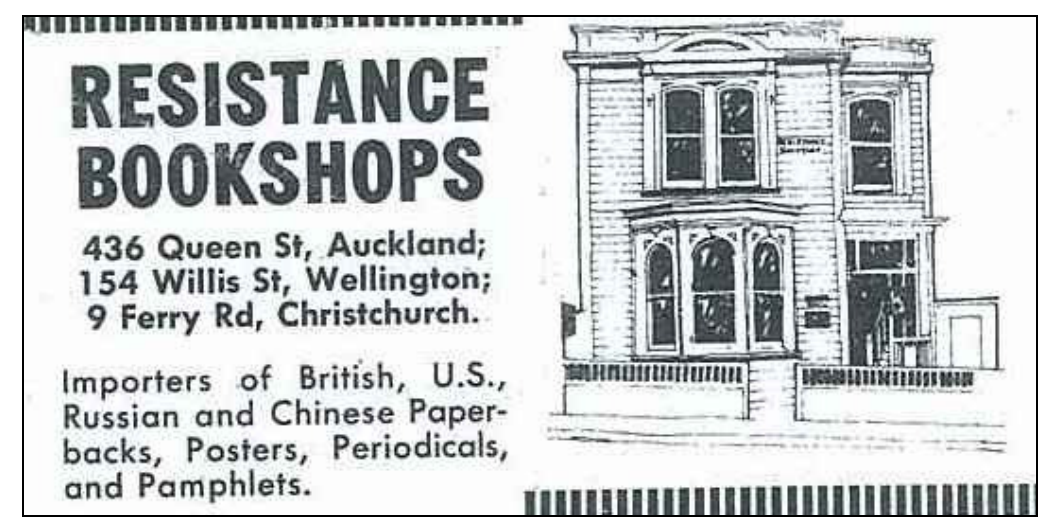

Figure 10 - Advertisement for the three bookshops placed in the New Zealand Listener, 6 August 1973 , p.50.

In December 1973 the first and only national meeting of the Resistance Bookshops was held. ${ }^{30}$ The meeting was attended by delegates from the three shops and individuals from Palmerston North, Dunedin and Hamilton. The meeting was first suggested by the Auckland shop who felt that it would be a good idea for the three shops to "thrash out our politics and a commercial agreement". ${ }^{31}$ The weekend-long meeting discussed a range of issues that were affecting the progress and sustainability of the bookshops in each city. The agenda gave each shop the opportunity to map out their background and political activity and relations with other left organisations. The meeting also gave those involved the opportunity to discuss the forms of organisation that the shops should work under, the issue of having a political line, and the viability

\footnotetext{
${ }^{29}$ Advertisement in the New Zealand Listener, 5 March 1973, p.47; Auckland Resistance to Richard Suggate, c. February 1973, p.2, TFML, Box 1, Folder 1.

301973 was the only year that all three Resistance Bookshops were operating at the same time.

${ }^{31}$ Ken Richardson to Richard Suggate, 29 August 1973, p.3, TFML, Box 1, Folder 2.
} 
and priorities of the shops. ${ }^{32}$ It highlighted some stark differences between the three centres, particularly the extent to which Wellington was isolated from the activity of the left in the city. This contrasted with Christchurch, which had been relatively successful in creating an action centre that was actually used by political groups and thus created an environment of interaction between Resistance and the left in the city. ${ }^{33}$ On returning from the meeting, Tony Currie of Christchurch Resistance reflected on the differences between the three cities in their fortnightly newsletter the "Resistance conference...brought home to Christchurch people the value of our Action Centre and political neutrality. Auckland and Wellington Resistances have become isolated groups in their cities". ${ }^{34}$

The meeting had very little impact on changing the trajectory of the three bookshops. No changes were made regarding how the shops were run, nor was a commercial agreement produced. What the meeting did do was reinforce the independent status and direction of each of the bookshops. Six weeks after the meeting the Auckland shop closed; Wellington and Christchurch each remained open until approximately late 1976.

\section{Auckland Resistance Bookshop}

In the late 1960s when political activity was mounting, the first Resistance Bookshop was established in Auckland by a group who were heavily involved with the political activity taking place in the city. Auckland was the most high profile setting for the 'movement' in New Zealand, with 'Jumping Sundays' and Tim Shadbolt becoming synonymous with the activities of radicalised youth. The opening of the Resistance Bookshop was an extension of this 'movement' activity, with the ideas that were being expressed at the "liberation" of Albert Park and various demonstrations that were being held around the country being practically applied to this space which would act as a coordinating point for such activity. A location was found at 436 Queen Street which was rented to Alan Robson on the condition that a small

\footnotetext{
32 'Conference $29^{\text {th }}-30^{\text {th }}$ December - Brief Synopsis', Wellington Resistance Bookshop Newsletter, 15 January 1974, TFML, Box 1, Folder 2.

33 ibid.

${ }^{34}$ Assistance, 16 January 1974, Vol.2, No.1, p.1, TFML, Box 1, Folder 3.
} 
bookshop would open. ${ }^{35}$ The premises were rented from the Auckland City Council costing \$30 per week. ${ }^{36}$ The space contained a large basement, darkroom, meeting room, four bedrooms and the bookshop. ${ }^{37} \mathrm{~A}$ team of people converted the space from offices to accommodation and the shop was fitted out with shelves and furnishings were acquired after the shop had opened. ${ }^{38}$ The fit out was carried out by volunteers and little money was available. The building's facilities were limited for a number of months, the residents even had no bath or shower for over six months. Despite the shortcomings in furnishings and finance, the shop opened in late 1969 first as a printing outfit and then as a fully operating bookshop in February 1970. ${ }^{39}$ An advertisement for the bookshop is shown in figure 11 .

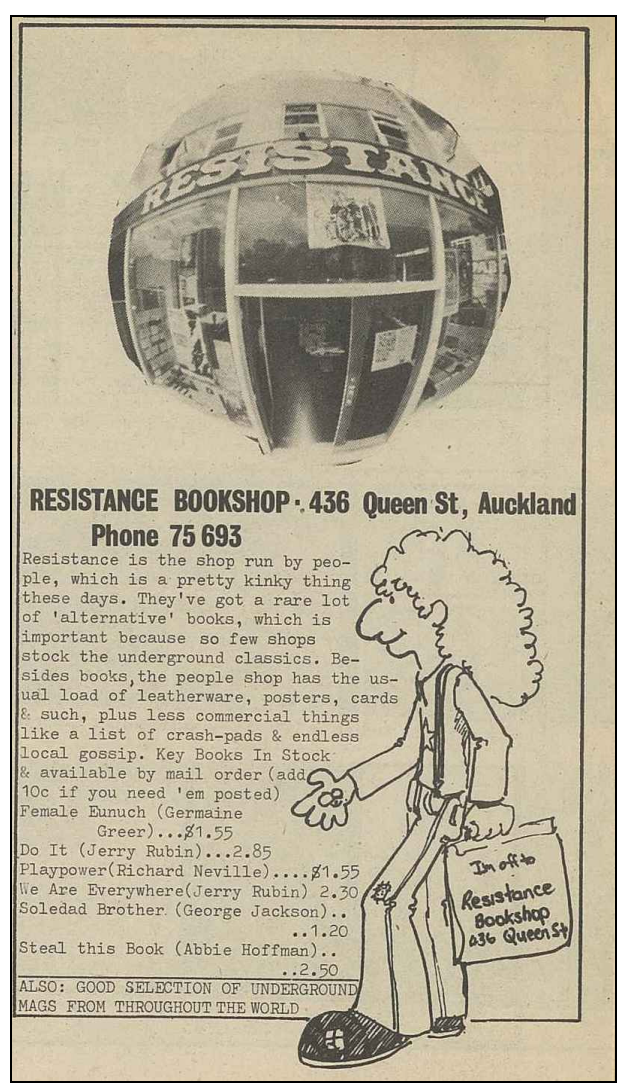

Figure 11 - Advertisement for the Auckland Resistance Bookshop, Earwig, Issue 6, c.1972, p.4.

\footnotetext{
${ }^{35}$ See page 26 for details on Robson's earlier political involvement. It is unclear how the initial payment of rent was made. Bolster, 1972, p.3.

36 'The Life and Times of Resistance', Craccum, University of Auckland, Vol. 46, Issue 21, 7 September 1972, p.5.

37 ibid.

${ }^{38}$ Bolster, p.4.

39 ibid., p.3.
} 
Sue Bradford, who lived at the shop during 1970, recalled that the motivation for people to become involved was quite simple: "it was about doing it ourselves, it was about a group of people working together collectively in a way that was comparatively new". ${ }^{40}$ Despite these aspirations to create a new kind of cooperative venture, the shop still existed within conventional business structures and therefore needed to be formalised in order to ensure that individuals would not be accountable for any loss. ${ }^{41}$ The bookshop was registered under the Companies Act 1955 as a limited liability company. Once this had been arranged the shop's lease was transferred from Robson to the company. The bookshop was registered under the name 'Four-three-six Queen Street Company Limited' and once it was registered a share structure was established. The bookshop sold shares for $\$ 10.00$ each and shareholders were able to purchase a maximum of $25 .{ }^{42}$ As of 1 April 1972 there were twenty-five individual shareholders, twenty-two men and three women. ${ }^{43} \mathrm{~A}$ meeting was held weekly and provision was made for an annual general meeting (AGM) and the submission of annual accounts to the Inland Revenue Department (IRD). The 'formal' organisational structure of the shop included the positions of shop manager, secretary, treasurer and the directors of the company. Over the four years that Resistance operated some of the people who managed the shop included Pat Bolster, Ken Richardson, Dennis Cooney, Ruebena Paraha and Graeme Minchin. There is no indication that managing the shop was ever a paid position.

An important economic base for the bookshop was the accommodation that was available on the premises. The number of residents living at Resistance varied, from the dozen or so people who lived there initially through to the three or four people living there by 1974. Financially, accommodation was crucial. Having tenants meant that there was a steady income to pay the bookshop's rent and less pressure on sales or finding donations to pay the rent. Bolster estimated that over three dozen people had lived at the shop at some point between 1969 and 1972. ${ }^{44}$ In 1972 each of the four tenants were paying $\$ 10.00$ a week in rent and expenses, with the shop paying $\$ 13.50$

\footnotetext{
${ }^{40}$ Bradford interview.

${ }^{41}$ Resistance even joined the Queen Street Business Association as a means to discuss the Association's policy on demonstrations.

42 Bolster, p.8.

43 ibid., p.9.

44 ibid., p.6.
} 
a week. ${ }^{45}$ This brought in a total income of $\$ 53.50$; $\$ 34.00$ was allocated for rent, $\$ 7.50$ for phone and electricity and $\$ 12.00$ for food for tenants. ${ }^{46}$

The remainder of the premises was used for the bookshop, printery, meeting space and offices which were hired out. In the meeting space Resistance could hold public meetings, film screenings and it was open to "progressive groups" to hold meetings at any time; political parties were not allowed to use the space. ${ }^{47}$ As noted in the introduction, this was part of their rejection of parliamentary politics. A food cooperative was also run through Resistance, however, this was financially separate from the shop. Individuals from Resistance went to the vegetable market each week to buy food for the food cooperative; photographs of this are shown in figure 12. The food cooperative operated by collecting $\$ 1$ from each person involved in the cooperative, people would then go to the markets and purchased whichever fruit and vegetables were cheapest on the day. ${ }^{48}$ This meant that there was little administration required for the shop because they did not have to bend to the requirements of what people were individually ordering.

The printing facilities at the shop included a printing press, which was obtained with the help of Chris Wheeler, a drawing board and a light table. The shop advertised that they were able to do electric stencils and printing of various qualities, from cheap newsprint to quality white paper. ${ }^{49}$ Individuals were able to use most of the equipment themselves but the actual printing equipment needed to be used under the supervision of someone with the skills to operate it. ${ }^{50}$ The shop produced a range of publications from small scale leaflets though to the larger scale productions like newspapers. Those involved with the bookshop wrote and produced a booklet on the Agnew demonstrations, several thousand were printed. ${ }^{51}$ Resistance also produced a one-off

\footnotetext{
${ }^{45}$ After tenants paid their portion of the rent, the amount that the bookshop had to pay was substantially less than the rental that the Wellington and Christchurch shops paid each week.

${ }^{46}$ Bolster, p.29.

47 ibid. p.6.

${ }^{48}$ Tim Shadbolt 'How to Run A Food Co-op', The First NZWEC, p.242.

${ }^{49}$ Auckland Resistance Bookshop Newsletter, November 1972, p.9, Jack Locke Papers: Resistance Bookshop, MB 116 Box 7, Macmillan Brown Library (MBL), University of Canterbury, Christchurch.

${ }^{50}$ Bolster, p.7.

${ }^{51}$ ibid., p.3; Bradford interview.
} 
newspaper, entitled Guerrilla, which came out in June 1970 and sold for five cents. ${ }^{52}$ Failing to sell, the paper left the shop $\$ 60$ in debt. In the end this was the only newspaper that was ever funded by the shop. ${ }^{53}$ The most frequently produced publication was the shop's newsletter, which the shop distributed to shareholders. The newsletters contained news about the shop's stock and finances, information about upcoming demonstrations, and a directory of political organisations in Auckland. The newsletter also often contained articles from international sources like the Underground Press Syndicate, covering stories of various political importance such as the legal system in Cuba. ${ }^{54}$

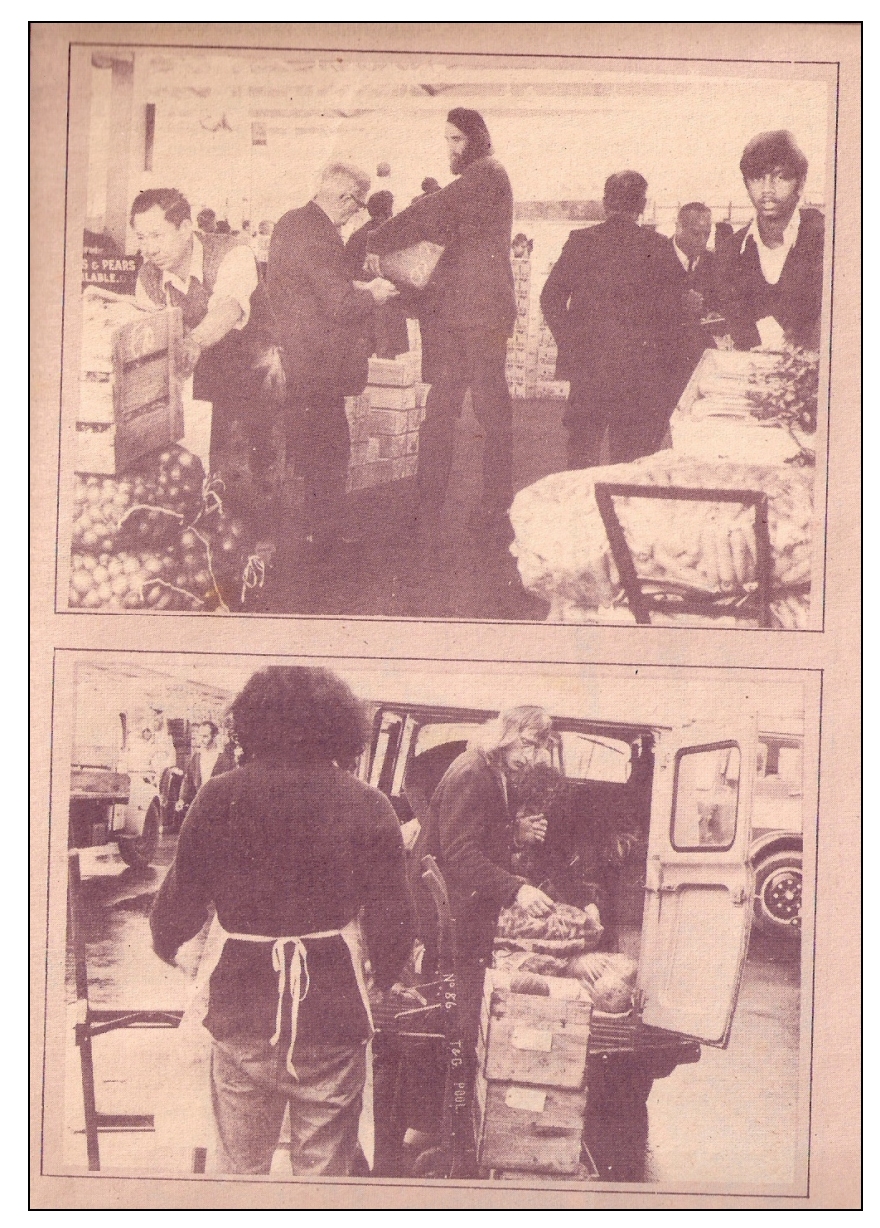

Figure 12 - Photograph of volunteers collecting for the Resistance Food Cooperative, First NZWEC, Wellington, 1972, p.243.

\footnotetext{
${ }^{52}$ Guerrilla, Auckland Resistance Bookshop, June 1970, 'Resistance Papers, Christchurch 1963-1987', Deposited by David Young, Central 316 Reference ANZC Archives, Christchurch City Library.

${ }^{53}$ Bolster, p.5.

${ }^{54}$ Auckland Resistance Bookshop Newsletter, 21 January 1973, TFML, Box 1, Folder 1.
} 
The bookshop was open from 9.00am to 5.00pm Monday-Thursday and until 9.00pm on a Friday. The shop produced an extensive catalogue of the books available, either in store or through direct order. The catalogue was split into the many different subject areas that the shop covered, from geographic areas with political significance like Latin America, Africa and Asia, through to more theoretical texts on socialism, anarchism, philosophy and mysticism, and finally to those books with more of a countercultural significance such as those on food, sex, communes, education and drugs. The catalogue was updated in the regular shop newsletters, with new arrivals listed along with those international titles expected to arrive in the forthcoming weeks. Theoretically, every sale was recorded in a sales book, which included the title of the book along with the amount paid. ${ }^{55}$ In the second year of operation, there was a great increase in the shop's finances and level of public support. Because of the success of New Zealand publications like Bullshit and Jellybeans and The Little Red School Book, there was an increase in sales and as a result the shop's bank account grew to $\$ 600$, enabling the shop to purchase a Gestetner. For a brief time the shop was able to function smoothly. ${ }^{56}$ Book sales were always uneven but there was a noticeable increase after the publication of these Alister Taylor publications. These texts were high profile and popular and often increased the shop's sales, particularly the New Zealand Whole Earth Catalogue (NZWEC), which was credited by Ken Richardson, the shop manager at the time, for enabling the shop to function "well". ${ }^{57}$ The shop reportedly sold 400 copies of Bullshit and Jellybeans and 300 copies of the The Little Red School Book by April 1972. ${ }^{58}$ However, this trend must not have lasted too long as by 1975 the $2^{\text {nd }}$ NZWEC stated that Resistance in Auckland closed due to "owing big amounts of money (including over $\$ 1200$ to the publishers of the NZWEC!)".59

Aside from the books and magazines listed in the catalogue, the bookshop also helped in circulating flyers and leaflets for political groups. This material will be examined more closely in chapter three but it is important to note that this ephemeral print was an important means of communication for political groups; it was cheap to produce

\footnotetext{
${ }^{55}$ These sales books are unaccounted for.

56 'The Life and Times of Resistance', p.5.

${ }^{57}$ Auckland Resistance Bookshop Newsletter, Christmas 1972, p.4, TFML, Box 1, Folder 1.

${ }^{58}$ Bolster, p.5.

59 'Alternative Bookshops', The 2nd NZWEC, p.352.
} 
and depending on how the material was distributed, it had the potential to reach a wide audience. The shop also sold leather and craft goods which were popular, and stocking them was seen as a way to "support the political people" who made them. ${ }^{60}$ Leather and craft goods were even listed as one of the shop's specialities being included on their letterhead along with books and posters. These goods seem to have been popular items but not necessarily easy to acquire, with the bookshop requesting a greater supply of them from their supporters in $1972 .{ }^{61}$ They were seen as a way to supplement the income of the shop as many of the texts that were stocked were slow selling. Stock was not always acquired through normal channels. In a newsletter the shop asked if anybody was going overseas and could send back some "incense, small craft goods and some books". This was a means to obtain popular products that could be difficult to import into New Zealand. ${ }^{62}$

The 'market' for left-wing publications in Auckland was fairly well-covered. Resistance co-existed with the 'Old Left' Progressive Bookshop in Darby Street, the SUP bookshop on Ponsonby Road and Red Star Books which was a break-away group from the SUP. ${ }^{63}$ These shops were not directly in competition with each other as they all offered their customers distinctly different political affiliations, with Resistance attempting to avoid sectarianism altogether. The Auckland University Bookshop also sold some of the same stock; many local alternative publications like Cock and The Paper were sold there as well as the more well-known Alister Taylor publications. Aside from the Resistance Bookshop, Auckland's counterculture was also served by the Love Shop, a store set up by ex-PYM members that was based on the concept of the Free Shop that was first opened by the Diggers in San Francisco. ${ }^{64}$ All goods were free and donated by the general public. The idea of a free store was promoted by the Counter Culture Free Press (CCFP), which reproduced an article from the Los Angles Free Press on how to set such a centre up. ${ }^{65}$ The interesting thing about the Love Shop in Auckland was that the majority of its visitors were middle

\footnotetext{
${ }^{60}$ Bolster, p.9.

${ }^{61}$ Auckland Resistance Bookshop Newsletter, November 1972, p.3, Jack Locke Papers: Resistance Bookshop, MB 116 Box 7, MBL, Christchurch.

${ }^{62}$ Auckland Resistance Bookshop Newsletter, Christmas 1972, p.4, TFML, Box 1, Folder 1.

${ }^{63}$ Access 2: directory of movement organisations, c.1972, TFML, Box 3.

${ }^{64}$ Michael William Doyle, 'Staging the revolution: Guerrilla Theater as a Countercultural Practice: 1965-68', in Peter Braunstein and Michael Doyle (eds), Imagine Nation: The American Counterculture of the 1960s and 70s, London and New York, 2002, p.80.

65 'How to open a free store', Counter Culture Free Press, No.4, April 1973, pp. 13-4.
} 
aged or pensioners, not the typical sort of people that you would expect at a countercultural experiment. ${ }^{66}$ The Love Shop was not a political space in the sense that Resistance was, rather the shop aimed to create an inclusive, collective environment that existed outside political or religious attachments.

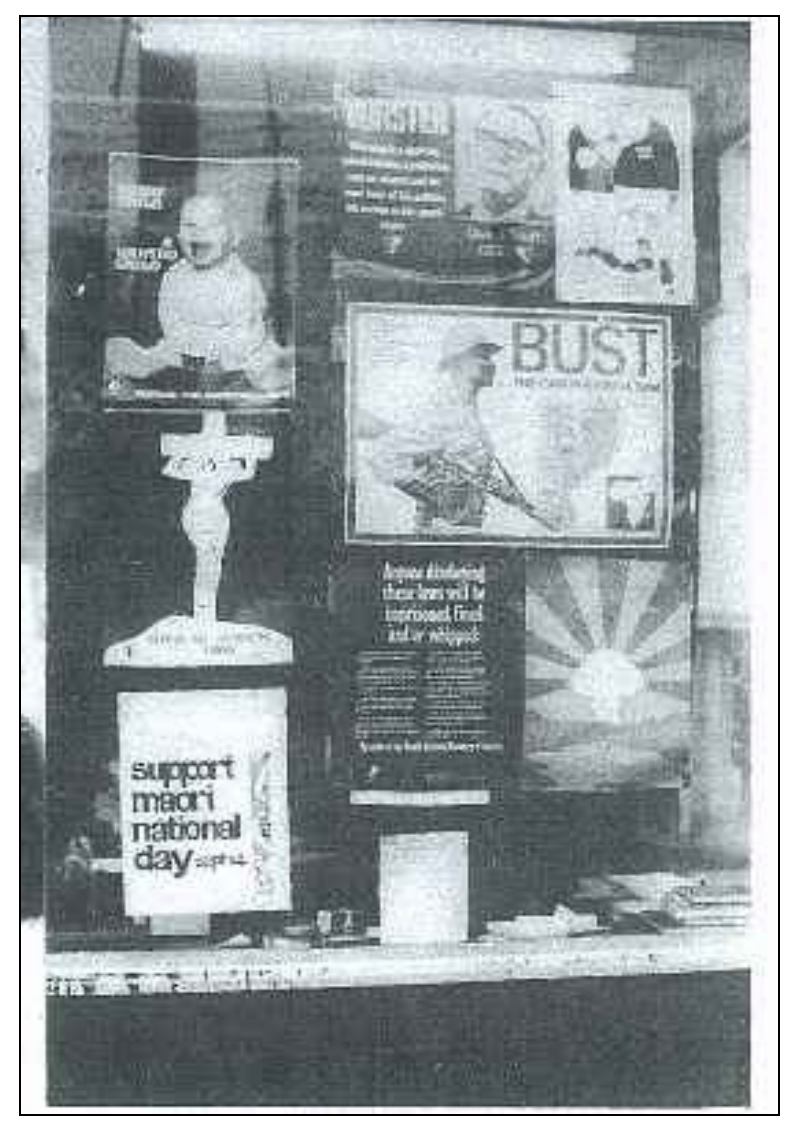

Figure 13 - Photograph of the shop frontage at Resistance Auckland, 'The Life and Times of Resistance', Craccum, University of Auckland, Vol. 46, Issue 21, 7 September 1972, p.5.

From the outset, when Resistance opened in 1969, it seems very clear that creating an ongoing relationship with political groups in the city was a central motivation. Resistance's shop window is shown in figure 13; the window is covered by a number of posters supporting various political campaigns. The shop reportedly had a sign in their window reading "THIS SHOP... is a cooperative venture with the aim of spreading new ideas and acting as a liaison for different groups and individuals who are struggling to create a more human whole. The shop has no religious or political affiliations..." ${ }^{67}$ Resistance was very careful to act as an umbrella organisation rather

\footnotetext{
66 'Auckland's Love Shop', New Zealand Listener, Vol. 66, 25 January 1971, p.57.

67 'Cooney and the Cosmic Constable', Earwig, Issue 81/2, c.1973, p.35.
} 
than an actual political group in its own right. In his shop manual, Bolster noted that Resistance had to tread carefully when it came to organising political activity, to avoid "becoming an organised political tendancy [sic] because, possibly wrongly, many felt that other groups would then see it as competition". ${ }^{68}$ Many of the shareholders were well-known within protest circles ranging from student protesters like Shadbolt and John Bower, who was imprisoned for his part in the dynamite attack on the Air Force depot in Parnell; through to poets like Stephen Chan. ${ }^{69}$ This range of shareholders meant that Resistance potentially had a close association with many different groups, however, this contact proved to be difficult to sustain. After the initial period of enthusiasm that surrounded the shop, where public meetings could draw in great numbers, it struggled to maintain its place within the 'movement'. Craccum reported that staff changes and limited income brought with them "bickering, dissatisfaction, and a crisis. Rent is up, turnover is down. Enthusiasm is low". ${ }^{70}$

The changing face of protest in the city meant that the support that the shop received also changed. The shop continued to stock texts which were linked with active political campaigns but by 1972 the shop had limited relations with the left in Auckland. A newsletter went out to all shareholders, supporters and left organisations stating that "Resistance is meant to be a rallying point for leftist activities. We have fallen down in this task". ${ }^{71}$ In an attempt to rectify this, Resistance called for people to become involved, to make Resistance not "just a service to other groups but part of the leftist involvement", ${ }^{72}$ One of the few developments that came in the weeks after this was Resistance's involvement with the Radical Election Campaign (REC) which was a loose alliance of Auckland groups that went under the banner of "Parliament is a fraud and elections are a farce". ${ }^{73}$ The group protested at the 1972 election meetings, disrupting them in an attempt to express that the government "does not act in the best interests in the majority of the people". ${ }^{74}$ Despite this new association, Resistance

\footnotetext{
${ }^{68}$ Bolster, p.6.

${ }^{69}$ Bower and two others attacked the depot, which stored equipment used by the RNZAF in Vietnam.

70 'The Life and Times of Resistance', p.5.

${ }^{71}$ Auckland Resistance Bookshop Newsletter, c.1972, p.1, Eph-B-ROTH-Resistance Auckland, ATL, Wellington.

72 ibid.

${ }^{73}$ Auckland Resistance Bookshop Newsletter, November 1972, p.8, Jack Locke Papers: Resistance Bookshop, MB 116 Box 7, MBL, University of Canterbury.

${ }^{74}$ Logan Moodley quoted in 'The Disrupters Close Up', 8 o'clock, Saturday 11 November 1972, p.9.
} 
continued to struggle to regain their place as a key organising base in the city and book sales continued to decrease. The shop's coverage in Earwig also soured, with the magazine describing that Resistance suffered from "ego trips, intolerance, stupidity, plots and bad vibes". ${ }^{75}$ It seems those writing for Earwig were annoyed by the lack of respect that Dennis Cooney received, particularly as he had committed a great deal of time to managing the shop after Bolster left in 1972. Earwig also had more widespread criticism of the bookshop, which was its isolation from the active left in Auckland. This coupled with the perception that the shop was run by a small clique with little public support led to Earwig's scathing coverage of the bookshop in 1973.

Resistance viewed this dislocation from the active left in Auckland as being merely a symptom of a greater problem, which they described as the so-called "paralysis of the NZ "left'". ${ }^{76}$ They were referring to the decreasing number of demonstrations taking place, the shrinking number of people involved in them and they also questioned the impact that protest was actually having. The shop published a news sheet that outlined the questions that the left would need to address in order to actually achieve change. The news sheet also looked at the downfall and perceived 'selling out' of many of the international New Left's most well-known members from groups like the SDS, Black Panthers and Yippies. ${ }^{77}$ In order for the bookshop to have an effective role within the 'movement' it was suggested that it became part of a wider political organisation that had a clear political programme, a disciplined discussion group and fulltime committed activists, concluding that "too many self-indulgent people have come and gone leaving no trace". ${ }^{78}$

Little became of this effort to forge a new direction, and the shop then faced claims that it was sectarian. From the time it started there was a concerted effort by those involved to ensure that Resistance did not become a politically aligned space. However, as the shop evolved this became a more pressing issue as there was an outside perception that the shop was in fact sectarian. In correspondence between Auckland shop manager Ken Richardson and Wellington shop manager Richard

\footnotetext{
75 'Cooney and the Cosmic Constable', Earwig, Issue 81/2, c.1973, p.35.

76 'Resistance News Sheet', c.1973, p.1, TFML, Box 1, Folder 1.

${ }^{77}$ ibid., pp. 1-2.

${ }^{78}$ ibid., pp. 2, 6 .
} 
Suggate, Richardson attempted to dispel Suggate's claim that "Auckland had become sectarian in its attitudes politically", arguing that "the discussion group... [that manages the bookshop] contains three anarchists, five un-defined... and one Trotskyist - so we cannot obviously be sectarian". ${ }^{79}$ Richardson emphasised that personal political affiliations should not be confused with Resistance's own position. He went on to express his disappointment and disillusionment with the activities of Resistance and the left more generally:

...Resistance, its resounding failure as a political organisation, the corruption, arrogance, incredible laziness and disunity of the many people that have "passed through' here has proved to be an invaluable lesson. Resistance in Wellington has proved to be no different, and many ex-Aucklanders are now in Christchurch mouthing exactly the same empty radical phrases that they uttered here. REC, guerrilla theatre have disappeared, HART exists in name only and PYM only surfaces around election time. People's Union and 'The Paper' struggle on - for the present that is. None have contributed to, or established any unified, viable political group..$^{80}$

Richardson's claims reveal his perception of the left to be both uncommitted and inactive. While he was correct that the initial momentum and unity that was created around the Vietnam War movement had diminished but there were still active campaigning occurring around other issues. The fracturing of the protest movement did not necessarily mean that political groups would have a short-lived existence. But the longevity of the women's liberation movement, Maori renaissance and the antiapartheid campaigns showed that a space, like Resistance, was not necessarily needed to foster political activity, nor was it necessarily supported as a common space.

Inaction or alienation from the left in the city were not the only problems that Resistance faced; financial difficulties, police scrutiny, vandalism and getting people involved with the bookshop were issues that affected the progress of the shop. From time to time it had to contend with unreceptive public, including one instance when a "disgruntled serviceman chucked a rubbish bin through the plate glass window" incensed as he was by Resistance's involvement with anti-Vietnam War

\footnotetext{
${ }^{79}$ Richard Suggate to Ken Richardson, 10 August 1973, TFML, Box 1, Folder 2; Ken Richardson to Richard Suggate, 29 August 1973, p.1, TFML, Box 1, Folder 2.

${ }^{80}$ Ken Richardson to Richard Suggate, 29 August 1973, p.1, TFML, Box 1, Folder 2.
} 
demonstrations. ${ }^{81}$ A side effect of this problem was that the shop then had issues with their insurance company. Their original insurers, Norwich Union, refused to renew their policy because they were perceived as being too much of a risk. Only after lengthy negotiations did State Insurance agree to cover the shop. ${ }^{82}$ As with the other two shops, Auckland Resistance also faced police attention and was raided a number of times with warrants ranging from suspected drug and weapon possession through to indecent publications. ${ }^{83}$ The shop was raided in regard to Itch, a controversial magazine printed in Wellington. It was also raided after there was a suspicious fire at the Papakura grandstand, police removed mailing lists and phone numbers and printing material from Resistance. ${ }^{84}$ These difficulties were however not as serious for the viability of the shop as its lack of both support and income, which duly led to the closure of the space once reputed to be the "gathering ground of all things pink and leftish". ${ }^{85}$

After the successes of its first few years, Resistance began to sink, losing volunteers, customers and the overall enthusiasm that the project had elicited when it became fully up and running in 1970. Income fell, book sales were down, but rent increased: the shop sunk into debt, owing $\$ 2890 .{ }^{86}$ In an article in Craccum that aimed to drum up support for the shop in 1972, its author suggested that the "underground has ceased to be a novelty and now had to earn its place. The mere existence of a 'movement' shop is no longer enough - it has to be functional - even professional - and yet retain the personal, non rip-off atmosphere that it has always had". ${ }^{87}$ The shop failed to reignite this interest, even after attempting to redefine their outlook and encouraging people to join the collective and help to create leadership within the left. ${ }^{88}$ At the Resistance Conference in December 1974, delegates from the Auckland shop were reported as expressing that "other political activities like printing and individual recruiting were more worthwhile than bookselling. The rent has also become

\footnotetext{
${ }^{81}$ Bradford interview.

${ }^{82}$ Ruebena Paraha to Richard Suggate, 3 July 1972, TFML, Box 1, Folder 1.

${ }^{83}$ Bradford interview.

${ }^{84}$ The letter is not specific about which grandstand was damaged. It is likely to be at Massey Park in Papakura. Ken Richardson to Richard Suggate, 29 August 1973, p.1, TFML, Box 1, Folder 2.

${ }^{85}$ Earwig, Issue 4, c.1972, unnumbered.

${ }^{86}$ Auckland Resistance Memorandum, undated, Eph-B-ROTH-Resistance, ATL, Wellington.

87 'The Life and Times of Resistance', p.5.

${ }^{88}$ Ken Richardson to Wellington Resistance, 19 July 1973, TFML, Box 1, Folder 2.
} 
prohibitive and Auckland is already served by Progressive Books". ${ }^{89}$ A shareholders meeting decided to close the bookshop, with Wellington being offered the chance to purchase their stock; all damaged stock was sold at forty per cent off..$^{90}$ The final date that the shop was open for business was 16 February 1974 but its actual closure was not as clear cut as Wellington was still receiving correspondence from Auckland about shop business in October 1974. ${ }^{11}$ The shop's stock and equipment was sold off by auction on 23 February 1974 and the printing gear was given to the People's Union. ${ }^{92}$ Many of those involved continued to be politically active, moving on to other forms of resistance. While Auckland Resistance struggled to sustain the political momentum which surrounded the shop in its early stages, for a time the shop was a vital part of the protest culture in Auckland. For over four years the shop was a 'radical space' within the centre of the city; it offered a permanent space for a 'movement' which was otherwise in constant flux.

\section{Wellington Resistance Bookshop}

As Resistance in Auckland began to gain momentum, their comrades in Wellington also opened a bookshop. The group, comprising mostly of individuals who had been involved with the Wellington PYM, secured premises in Cuba Street and opened the Wellington Resistance Bookshop in June 1970. 236 Cuba Street, located between Abel Smith Street and Vivian Street, consisted of one room and a small kitchen downstairs where the bookshop was located, and an upstairs bedroom which could be rented out. The shop was open from 10-5pm Monday to Thursday, and 10-9pm on Friday. It carried a relatively small amount of stock and was not yet equipped with printing facilities. ${ }^{93}$ However, these premises were only short-term. The bookshop was destroyed by a fire in the early hours of 29 November 1970, which engulfed both

\footnotetext{
89 'Conference $29^{\text {th }}-30^{\text {th }}$ December - Brief Synopsis', Wellington Resistance Bookshop Newsletter, 15 January 1974, TFML, Box 1, Folder 2.

${ }^{90}$ Auckland Resistance to Wellington Resistance, 4 February 1974, TFML, Box 1, Folder 2.

${ }^{91}$ Graeme Minchin to Richard Suggate, 31 October 1974 and c. December 1974, private collection of Richard Suggate.

${ }^{92}$ There are no records of whether creditors sought payment and what happened to the surplus stock and equipment. Notice of Auckland Resistance's closure, 4 February 1974, Eph-B-ROTH-Resistance, ATL, Wellington; Auckland Resistance to Wellington Resistance, 4 February 1974, TFML, Box 1, Folder 2.

${ }^{93}$ Advertisement in the PYM Rabble, No.3, August 1970, p.4.
} 
floors and severely damaged the building. ${ }^{94}$ In the days after the fire, the shop front was tagged with the words 'PYM' and "We Will Reopen" and a photo of the burnt shop front was published in Bullshit and Jellybeans, shown in figure $14 .{ }^{95}$ There was speculation about the cause of the fire. In the aftermath of the June anti-tour protests in Wellington, threats had been made against the shop in the weeks preceding the fire. Two years later in an article in Cock, its editor Chris Wheeler reflected on the fire, speculating that while it was lit by 'persons unknown' they were "undoubtedly close enough to the Police to ensure that only the most cursory investigation was carried out". 96

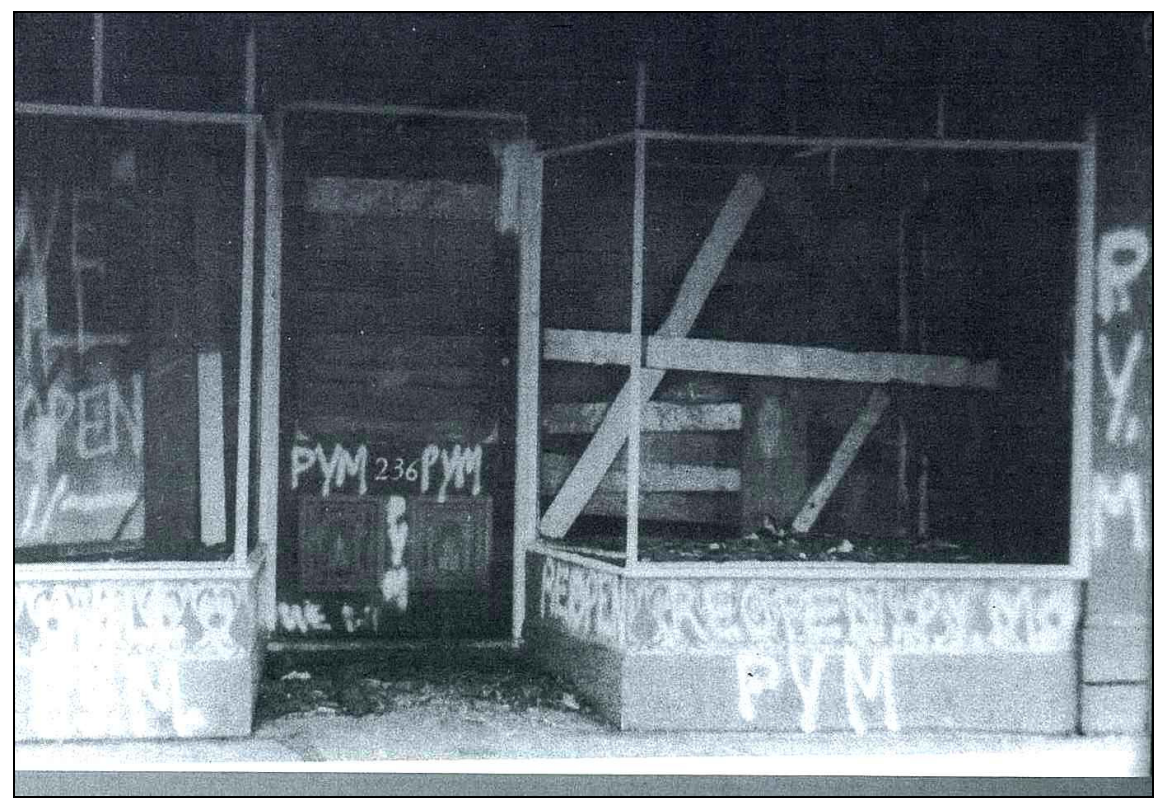

Figure 14 - The aftermath of the fire at the Resistance Bookshop in Wellington. Tim Shadbolt, Bullshit and Jellybeans, 1971, p.130.

After a short time new premises were found at 154 Willis Street. Resistance was able to reopen in March 1971 due to a $\$ 500$ insurance payout. The building was a two story house; the bottom level was rented by the Merchant Adventurers of Narnia, who sold imported Asian and 'hippie' goods. The top level was rented by the bookshop for \$25 a week, and consisted of two rooms upstairs and the kitchen, the latter to be occupied by an old printing press, originally owned by Cockerel Press. ${ }^{97}$ Unlike the

\footnotetext{
94 'Fire Guts Cuba St Bookseller', The Evening Post, 30 November 1970, p.9.

${ }^{95}$ Shadbolt, p. 130.

96 'Of Libels and the Police Conspiracy Against the Free Press in NZ', p.5.

${ }^{97}$ Alan Thorley, 'Continuing Resistance', New Zealand Listener, 6-12 September 1975, Vol.80, No.1866, p.22; Suggate interview.
} 
premises in Cuba Street there was no accommodation and only a limited area for people to meet, as the bookshop took over most of the two rooms. The 'Cuba Bookshop Society Ltd.' was formally set up as an incorporated society on 23 June 1971 under the Industrial and Provident Societies Act 1908. ${ }^{98}$ Prior to this there had been no formal organisational structure. Having the status of an incorporated society meant that the bookshop was non-profit making and was governed by an appointed committee who had to hold an AGM and submit annual accounts to the IRD. The incorporated society also established an open shareholding where anybody could purchase a $\$ 2$ share in the bookshop, with a maximum of $\$ 600$ of shares allowed. Shareholders had voting rights at the AGM and were able to cast only one vote regardless of the number of shares they held. Shop manager Richard Suggate recalled that the open shareholding both "encouraged people to give a donation to help set the shop up... [and made] ... the people who were working in the shop accountable to a management committee". ${ }^{99}$ The cooperative nature of Resistance was an important part of its structure as it was in stark opposition to the conventional structures of commercial business. Resistance encouraged people to buy shares: "in these days of monopoly control it is vital for an alternative voice to exist. You can assist in setting up this voice". ${ }^{100}$ By May 1975, Wellington had sold approximately 844 shares, with 127 individual shareholders. ${ }^{101}$ Shop manager Richard Suggate was a major shareholder with over one hundred shares, over a \$200 'investment' in the shop. The shareholders were given share certificates signed by the secretary of the society, as shown in figure 15.

On a day to day level the bookshop was run by volunteers, with the shop attempting to attract people by presenting itself as "an opportunity to act out socialist fantasies". ${ }^{102}$ It was run as a collective, with the work being shared via a roster, but as with Auckland, the general running of the shop was overseen by the shop manager. The manager was responsible for the shop's paperwork, ordering books, looking after the printing press and coordinating workers. This position seems to have been largely

\footnotetext{
${ }^{98}$ Department of Justice to the Cuba Bookshop Society, 23 June 1971, private collection of Richard Suggate.

${ }^{99}$ Suggate interview.

100 'Resistance: Community owned and controlled to distribute ideas and information', Newsletter, c.1972, p.3, private collection of Richard Suggate.

${ }^{101}$ Wellington Resistance Shareholders Book, private collection of Richard Suggate.

${ }^{102}$ Wellington Resistance Bookshop Newsletter, c.1972, private collection of Richard Suggate.
} 
voluntary. As the shop was never financially strong, there was no chance that a fulltime shop manager could be employed on a full salary. For a time in 1974, the shop was able to pay its manager $\$ 15$ a week; however, this was ended after the shop's financial position weakened. ${ }^{103}$ The people working in the shop were often shareholders and they did not necessarily give up large amounts of their time, rather they could be rostered on for one or two shifts a week, with lunch or travel money given to those working a full day. ${ }^{104}$ As well as working in the bookshop, people were also encouraged to participate in the weekly meetings which were held every Friday night; these meetings discussed "anything and everything to do with the shop and the various goings on around town". ${ }^{105}$ In contrast the AGM was a formally instituted meeting with an agenda, and a financial statement supplied to attendees in advance.

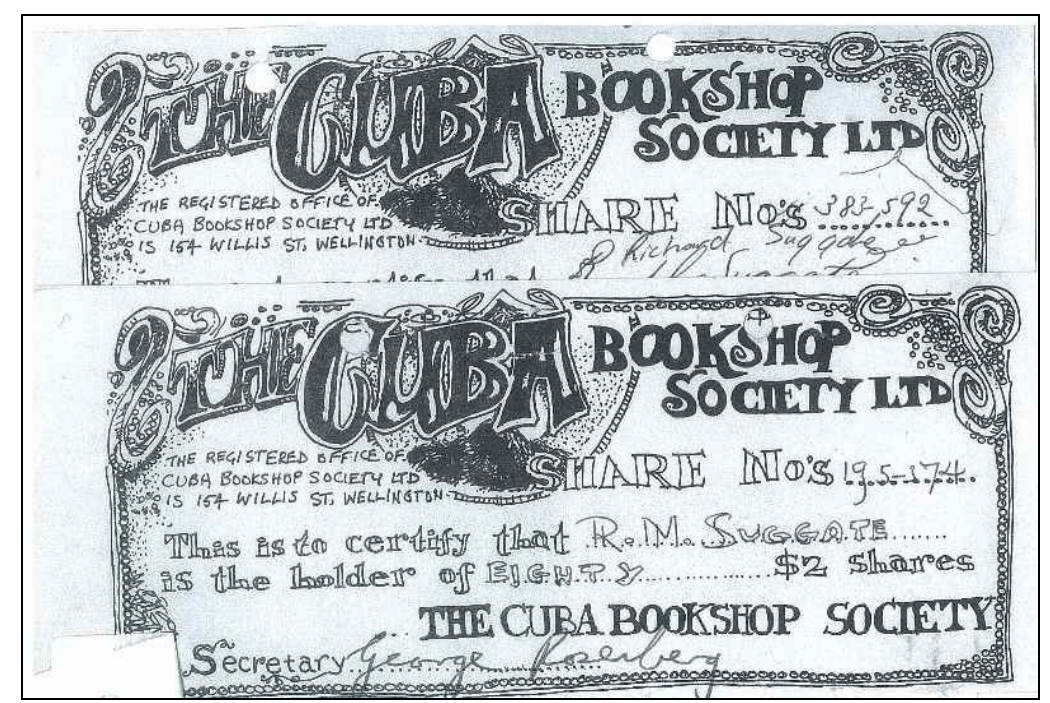

Figure 15 - Wellington share certificates 1971, private collection of Richard Suggate.

The centre of Resistance was of course the bookshop; at its basic level it was a place where people could get left-wing books. The small scale of the operation did not affect the range of books that the shop was able to stock and their shelves included books on anarchism, feminism, New Left politics, Third World liberation movements, United States imperialism, counterculture and a range of fiction. Expanding the range of books available was the shop's first priority, which indicates that the bookshop saw that there was much power in the types of publications they were stocking. By

\footnotetext{
103 Thorley, p.22.

104 'Resistance Bookshop' Leaflet, 1972 , private collection of Richard Suggate.

${ }^{105}$ Nose 3, Wellington Resistance Bookshop, November 1973, p.1, private collection of Richard Suggate.
} 
expanding their selection they would ideally draw in customers with political interests wider than the popular countercultural titles. For the first two years in Willis Street the shop engaged predominantly in bookselling rather than in acting as a coordination centre and meeting place like the Auckland Resistance. In a newsletter to their shareholders, the bookshop commented that "we are only committed to selling books as we feel that it is necessary to have a reasonably sound base before we expand into other projects". ${ }^{106}$ Those involved in Wellington had aspirations to expand Resistance into more of an 'action centre' type operation but this was determined by the suitability of the shop's location, finances and the commitment of those involved. An advertisement for the bookshop is shown in figure 16.

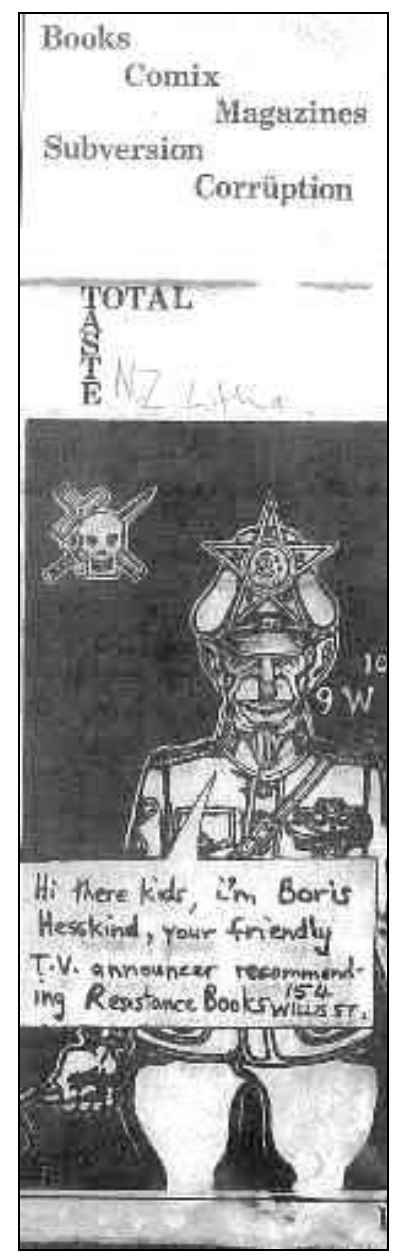

Figure 16 - Advertisement for Wellington

Resistance Bookshops, undated, private collection of Richard Suggate.

Aside from books, Resistance also sold newspapers and magazines from New Zealand and around the world. Local publications like HART News, Cock and The People's Voice were sold alongside international newspapers like the Georgia Straight,

${ }^{106}$ Wellington Resistance Newsletter, November 1972, p.3, private collection of Richard Suggate. 
Anarchist Weekly Freedom and the Los Angeles Free Press. International periodicals were not imported regularly but when in demand and usually in small numbers. Political posters were also stocked and depicted local campaigns, international communist propaganda, and Black Nationalist icons like Amilcar Cabral. ${ }^{107}$ The shop also sold leather goods and badges, both of which proved popular. Political groups were able to leave their leaflets and fliers for people to casually pick up thus ensuring that Resistance became part of a communication network for both activities going on in the city but also as part of a national network. Information from groups like CAFMANZ and HART or the other Resistance Bookshops could all be circulated through the bookshop. Resistance was also a means to distribute information that was produced at the shop's printery.

Resistance may have filled a gap in the book market in Wellington but this is not to say that Wellingtonians had a limited choice in booksellers. There were three other 'alternative' or political bookshops already operating during the 1970s; these included Printed Matter Books, Unity Books and International Books. Printed Matter Books, located up Plimmer's Steps, off Lampton Quay, was owned by Alister Taylor and sold a range of other political and countercultural titles. Unity Books was an independently owned bookshop, established in 1967 and located down the road from Resistance on Willis Street. Unity also wanted to provide a wider range of books for their customers, selling New Left and countercultural titles, history, philosophy and literature. ${ }^{108}$ Comparing the titles sold, it is evident that there were many crossovers between the two bookshops. However there was very much a type of literary community around Unity which Resistance neither had nor sought. Unity also had less of a political focus. International Books was a political bookshop on Willis Street that also stocked radical material as well as second-hand books. ${ }^{109}$ International Books opened in 1970 in the space that had previously housed Modern Books. International Books later became Liberation Books and during a period in which Resistance was struggling financially, those involved with Resistance suggested that the two shops amalgamate. Liberation's owner Chris Frankel, however, declined this offer, wishing to remain independent as she did not want the responsibility of running a cooperative

\footnotetext{
${ }^{107}$ An Amilcar Cabral poster that was hung in the shop is part of the TFML.

${ }^{108}$ For more information on Unity Books see A Willis Street Bookseller Celebrating 20 Years, Wellington, 1987 and Rogers and Rogers, pp.71-3.

109 'New Wellington Left Bookshop', Cock, Issue 9, December 1969, p.19.
} 
bookshop. ${ }^{110}$ Later when Resistance closed approximately at the end of 1976, Liberation acquired all of Resistance's stock and took over their Book People account, which was a major wholesaler of American countercultural books. ${ }^{111}$ While there was a cross-over in terms of what was being stocked between these four bookshops, Resistance offered something substantially different. First of all it was a cooperative, a bookshop whose customers could become shareholders and participate in the running of their store. Secondly, Resistance offered something wider than just the consumption and distribution of books. It was a space that gave readers the chance to engage and participate in politics. This goal may have been difficult to realise at times but the intention was there and it continued to be pursued by those involved.

Once the level of stock was improved in the bookshop, Resistance expanded into their other major role - the production of printed material. 'Resistance Print' was set up with the help of Roger Cruickshank in 1973. The press had previously belonged to Cockerel Press and took up residence in the kitchen behind the bookshop. Along with the press, the shop also purchased an electric typewriter, Gestetner and electric stencil. It was hoped that they would be paid off by the business generated by having an operating printery. ${ }^{112}$ However, there were problems with the press as upkeep proved difficult. Very few people had the skills to maintain the equipment and the offset printer was out of use for much of the year due to damaged rollers. ${ }^{113}$ In spite of technical difficulties, the shop was still able to produce publications, with shop manager Mark Barry producing Nose, the shop's newsletter, and the controversial magazine Itch, from the shop's press.

The bookshop in Wellington faced a series of problems, particularly in relation to its finances, its relationships with the left in the city and to a lesser degree the issue of police scrutiny. Financial troubles persisted. From the time that the shop opened in Cuba Street through to its closure in 1976, those running the shop made constant appeals in newsletters for more funds. In 1973, from a weekly turnover of $\$ 150$, the shop made a profit of only $\$ 9$ a week after the weekly expenses of rent, utilities,

\footnotetext{
${ }^{110}$ Wellington Resistance Newsletter, August 1974, private collection of Richard Suggate.

${ }^{111}$ Book People Invoice, 27 February 1976, private collection of Richard Suggate.

${ }^{112}$ Wellington Resistance Newsletter, March 1973, private collection of Richard Suggate.

${ }^{113}$ Chris Wheeler discussed the benefits of offset printing in an article entitled 'Starting Your Own Underground Printing Press', The First NZWEC, p.26; Wellington Resistance Newsletter, 9 November 1973, private collection of Richard Suggate.
} 
postage, lunch and travel money for workers and debt repayments were paid. ${ }^{114}$ This left virtually no money to increase stock levels and in an attempt to supplement this income the shop sought a weekly collective pledge of $\$ 30$ by their supporters to enable them to expand. ${ }^{115}$ This scenario continued to affect the sustainability of the bookshop and aside from the shares purchased, the shop had to rely on meagre weekly earnings. The biggest liability for the shop was the large debt that it had accumulated from acquiring stock. In November 1973 the bookshop owed $\$ 4166.20$ to its creditors and after paying its weekly expenses, the shop had an average of only $\$ 100$ to pay its debts. ${ }^{116}$ The shop owed both national and international distributors, with Alister Taylor even threatening legal action due to unpaid book orders. ${ }^{117}$ From the time that Resistance reopened in Willis Street, there were concerted efforts to increase its stock, but this too created difficulties. Salient reported that since its founding the bookshop's stock had increased in value from $\$ 300$ to about $\$ 2000$, however, public interest had not increased comparably and left quite a gap between the level of stock that had been purchased and the actual public demand. ${ }^{118}$ The shop also faced a trading loss at times. The notes contained alongside the annual accounts for the year to March 1973 offered a few suggestions as to why there was a trading loss; selling books at discounted prices, shoplifting and negligible profit when books were sent to other Resistances. ${ }^{119}$ The bookshop was also burgled numerous times, losing around \$70 in cash each time. ${ }^{120}$ All of these factors had major implications for the financial stability of the shop.

Resistance attracted police attention for a number of reasons. Firstly there were suspicions that drugs were being sold there; secondly Itch had aroused the attention of 'anti-pornography' factions; and thirdly the shop was connected with the political activity in the city and therefore was a key surveillance point for police. Resistance

\footnotetext{
114 'Resistance Bookshop may be best - but...', Salient, Victoria University of Wellington, 21 March 1973, p.4; Wellington Resistance Bookshop Flyer, c.1972, private collection of Richard Suggate. ${ }^{115}$ Wellington Resistance Bookshop Newsletter, c.1972, private collection of Richard Suggate.

${ }^{116}$ Wellington Resistance Bookshop Newsletter, 9 November 1973, private collection of Richard Suggate; Wellington Resistance Newsletter, August 1974, private collection of Richard Suggate.

${ }^{117}$ Richard Suggate to Malcolm Gramaphone, 6 October 1973, Malcolm Gramaphone: Papers relating to 'Counter Culture' and 'Resistance' 1965-1973, Misc-MS-0293, Hocken Library, Dunedin.

118 'Resistance Bookshop may be best - but...', p.4.

${ }^{119}$ Cuba Bookshop Society Limited Accounts April 1972 to March 1973, 11 September 1973, private collection of Richard Suggate.

${ }^{120}$ Richard Suggate, 'More Resistance - Or No Shop', Salient, Victoria University of Wellington, Vol.35, No.19, 3 August 1972, p.5.
} 
was raided by police a number of times. One high profile example was over the publication of Itch. This was a magazine that was highly controversial because it was aimed at secondary school students and had a large sexual content. In November 1973 the Wellington bookshop was raided, fifty copies were confiscated and were consequently handed over to the Indecent Publications Tribunal (IPT) for assessment. ${ }^{121}$ The issue contained articles on women and sex, what to do when confronted with the police and a 'how to' guide for having sex. ${ }^{122}$ The issue also included a covering photograph of three pre-pubescent naked girls that had caused controversy when London magazine $O Z$ published it three years earlier, as shown in figure $17 .{ }^{123}$ Nude images were often included in underground magazines during this period as a means to challenge conventional attitudes about sexuality and the body. However, many individuals involved with Resistance believed there was little political merit in Itch, which essentially "used sex as a selling point". ${ }^{124}$

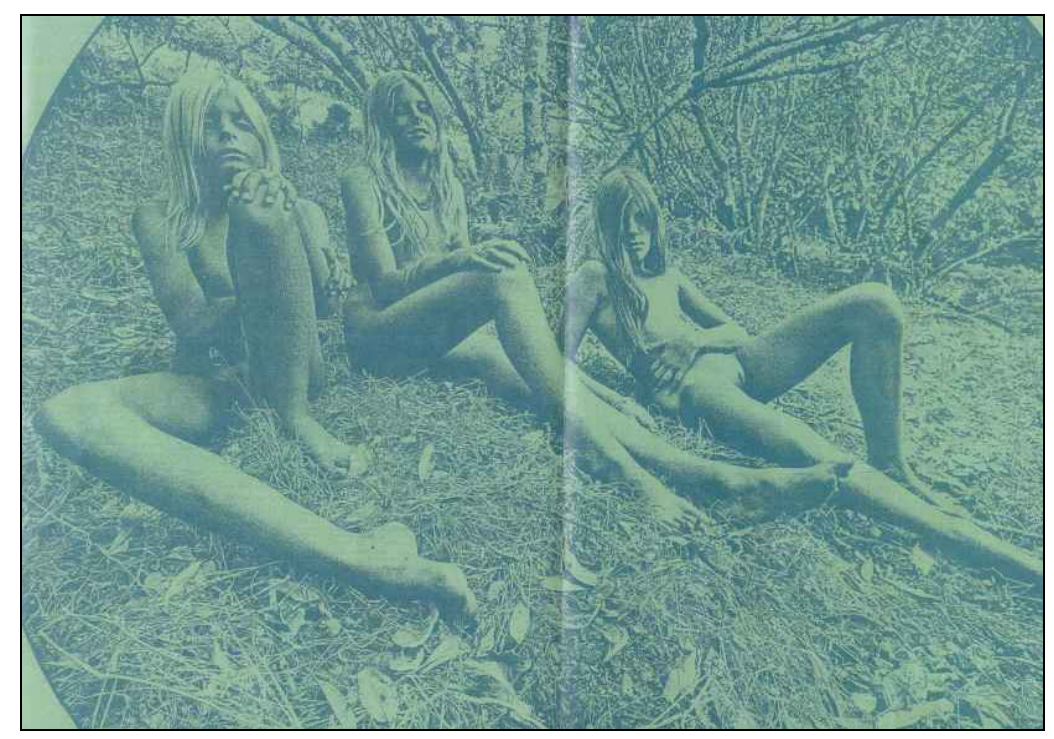

Figure 17 - The controversial photograph from $O Z$ magazine, reproduced for the cover of Itch, No.2, 1972.

The Christchurch and Auckland shops were also raided to confiscate their copies of the magazine and Ferret reported that the publishers Mark Barry and Richard Keene had been chased from Stratford to Hawera having 348 copies confiscated in the

\footnotetext{
${ }^{121}$ Nose 3, Wellington Resistance Bookshop, November 1973, p.2, private collection of Richard Suggate.

${ }^{122}$ Itch, Issue 2, c.1973, ATL, Wellington.

${ }^{123}$ Previously published in OZ, London, Issue 27, 1970, pp.24-5.

${ }^{124}$ Ken Richardson to Richard Suggate, 29 August 1973, p.1, TFML, Box 1, Folder 2.
} 
process. The events were portrayed as an attempt by the state to suppress alternative ideas. ${ }^{125}$ The IPT subsequently declared the issue indecent in $1974 .{ }^{126}$

Cannabis use was becoming increasingly common in New Zealand and the culture surrounding this was reflected by the number of drug related titles stocked by the bookshop. Titles like The Book of Grass, The Hippie Papers and the Cannabis Cultivators' Guide were read and treated as part of the broader move "away from conventional thoughts and behaviour" that drugs were thought to stimulate. ${ }^{127}$ Drug use thus became associated with political activity though in fact, these were elements that did not necessarily go hand in hand. As discussed earlier much of the left disagreed with drug use and it consequently caused major divisions within the 'movement'. When the Wellington bookshop had adjoining accommodation, the shop was raided once because of suspected drug dealing but Suggate recalled that generally the police tended to leave the shop alone because they "didn't want to create some kind of political publicity". ${ }^{28}$

State surveillance may have also taken a different, more covert form. For a period of time Wellington had an unknown individual acting as its treasurer. He was not known by those involved and casually volunteered for the position. At meetings he offered few opinions and after a few months he disappeared with the bookshop's account records, though no actual money was taken. After a number of attempts by Suggate to retrieve this information, he abandoned his attempts and the shop suspected that the individual was working for the Security Intelligence Service (SIS). ${ }^{129}$ This suspicion was never proved but within political groups during this period it was assumed that the police and the SIS were engaging in this type of surveillance. Christchurch Resistance had an undercover detective join their meetings which were being held to plan a demonstration against the Pacific Basin Economic Council meeting that was being held in the city; his position was later discovered and the detective was

\footnotetext{
${ }^{125}$ As Wellington and Christchurch were raided first, the Auckland bookshop expected a visit by police and disposed of their copies of Itch. 'Itch', Ferret, Issue 4, December 1973, page unnumbered.

${ }^{126}$ Indecent Publications Decision No.766, Itch No.2 (Delivered 10.1.1974), listed in Perry, p.30.

${ }^{127}$ Quoted from Yska, 1990, p.126; George Andrews and Simon Vinkenoog (eds) The Book of Grass: An Anthology of Indian Hemp; New York, 1967; Edited by Jerry Hopkins, The Hippie Papers: Notes from the Underground Press, New York, 1968; Cannabis Cultivators' Guide, Wellington, 1970.

${ }^{128}$ Suggate interview.

129 ibid.
} 
confronted about it. ${ }^{130}$ In terms of the SIS, reportedly ten per cent of their work during this period dealt with protest and dissident groups, looking at both individuals and groups involved with 'subversive' activity. ${ }^{131}$ Groups like HART were also subject to SIS spying. Trevor Richards, one of the leading figures in HART, had an SIS agent living next door to him in 1973, who reportedly wanted "to keep track on the undesirable hippies next door". ${ }^{132}$ This surveillance did not stop HART's activities, nor did it restrict Resistance; rather the actions of the SIS and the police highlighted that 'anti-Establishment' activity was seriously regarded by the government to the extent that covert action was carried out.

The shop also faced spatial and location issues. The bookshop was on the second floor of the house which meant that it had no shop frontage nor did it have much foot traffic. The house at 154 Willis Street also had no accommodation and very little meeting space. The effectiveness and development of the shop was therefore limited by its location. A shop newsletter attributed the shop's lack of progress to "an almost non-existent economic and organisational base - largely due to a lack of living quarters which have helped to sustain continuity of personnel in other centres". ${ }^{133}$ To rectify this, the group sought a new, bigger location, which was later found at 144 Willis Street in a condemned house that was formerly the Centreway Guest House. ${ }^{134}$ Over $\$ 1000$ was needed to secure the building's lease so loans were obtained from the shop's supporters to facilitate the move. Thirteen people contributed including members of National Organisation for the Reform of Marijuana Laws (NORML), the CPNZ and some of the shop's shareholders. ${ }^{135}$ The new shop opened in May 1975 providing more space for meeting rooms and for the first time enabling the shop to provide permanent accommodation. This provided the shop with a means to supplement their income through individual rent payments. The premises cost $\$ 80$ per week, the eight people who lived there each paid \$12 a week and three upstairs rooms were also rented out to organisations, this ensured that future rent payments would not

\footnotetext{
${ }^{130}$ Bill Rosenberg, interviewed 19 August 2006.

${ }^{131}$ Michael Parker, The SIS, Palmerston North, 1979, p.136. Also see Butterworth, 2005.

132 Richards, p.107.

${ }^{133}$ Wellington Resistance Newsletter, 30 November 1973, Eph-B-ROTH-Resistance, ATL, Wellington.

134 Thorley, p.22.

${ }^{135}$ The list of individuals that contributed loans is included in the Wellington Resistance Shareholders Book, private collection of Richard Suggate.
} 
put as much pressure on the shop's sales. ${ }^{136}$ The inside of the bookshop at 144 Willis Street is shown in figure 18.

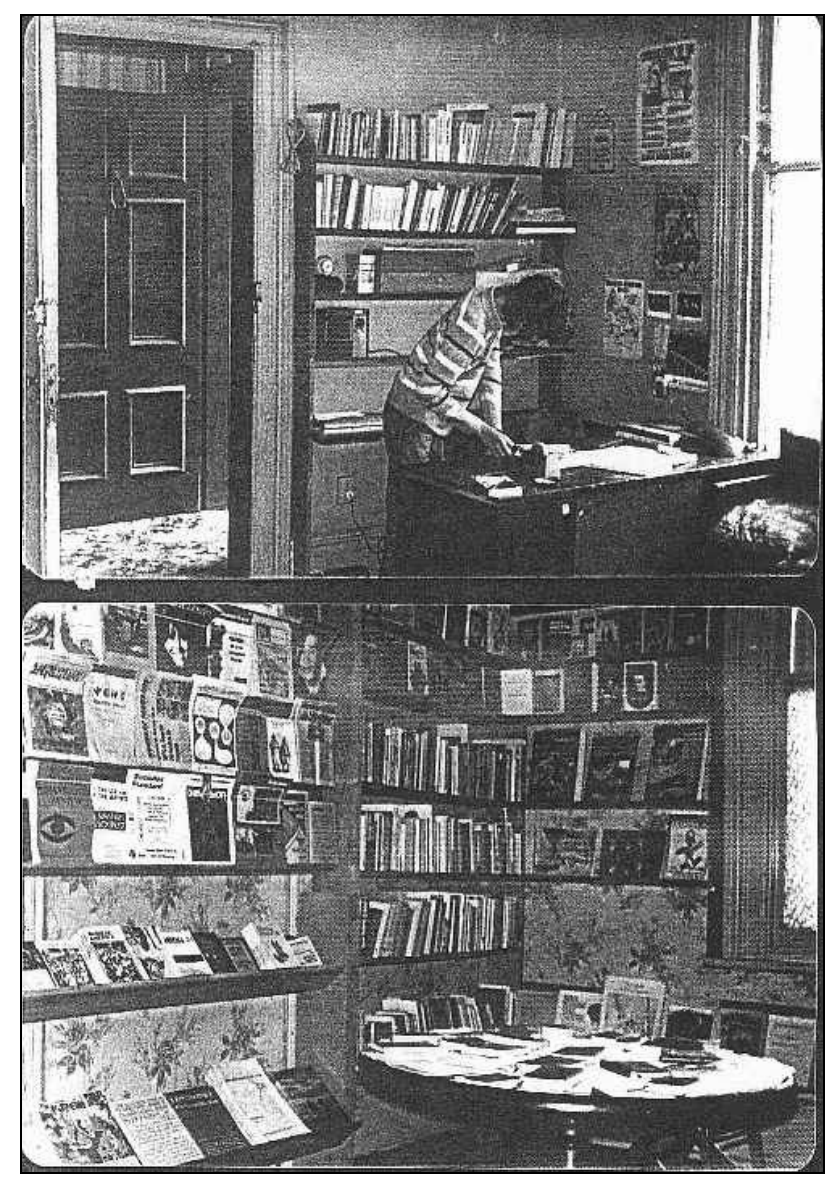

Figure 18 - Photographs inside the shop at 144 Willis Street, Wellington, c.1975, private collection of Richard Suggate.

Soon after Resistance moved into their new premises, an article was published on the bookshop by the Listener. ${ }^{137}$ The article covered the shop's history, finances, current state and the difficulties associated with running the collective. It is an objective view of the bookshop, far removed from the sensationalist coverage that newspapers like the Auckland Star subjected the bookshops to. Suggate commented that the Wellington bookshop received very little media coverage and he sensed that the interest that was generated looked more at the shop as a "quirky thing". ${ }^{138}$ The bookshop was the subject of two articles in Salient but the Listener article was the

\footnotetext{
136 Thorley, p.22.

${ }^{137}$ Alan Thorley, 'Continuing Resistance', New Zealand Listener, 6-12 September 1975, Vol.80, No.1866, p.22

${ }^{138}$ Suggate interview.
} 
only time that the shop was the subject of a detailed profile within the mainstream press.

The new location was slightly different from the old premises. The new shop did not have a printing press as it had been sold to a group of women who set up the Herstory Press, a feminist press located in the Aro Valley. Even without the press, the new premises allowed the shop to expand so that it had a wider function, much like that of Christchurch. Suggate recalled that the motivation for the shift was that the "bookshop [had] operated in a passive role, there were certain aspirations for it to become a 'Resistance' should we say or [a centre for] political activity". ${ }^{139}$ Resistance rented out space to the SUP and WONAAC and a non-affiliated information centre for women was also set up in one of the rooms. The new shop aimed to enable groups to coexist under the same space. This idealism was questioned by the former manager of Resistance in Auckland, Graeme Minchin, who wrote to Suggate stating that "I don't understand the 144 setup. I may be a bit of a fanatic but I find it hard to invisage [sic] libertarians cooperating peaceably with Stalinists such as the SUP and Salient crew". ${ }^{140}$ Minchin's doubts about the arrangement proved accurate, as the bookshop had limited success in acting as a space to bring political groups together. In the Listener article in 1975, Suggate commented that the "whole left-wing scene is a mess...in Wellington the different groups - the Communists, the Maoists, the Socialist Unity Party, the Trotskyites - won't associate with one another. They come in, buy their books, and go". ${ }^{141}$ This was an issue that also affected the Auckland shop, the dynamics of the more staunchly sectarian cities proved to be quite different to that of the situation in Christchurch. It is difficult to establish the reasons as to why Auckland and Wellington were more sectarian than Christchurch. One could speculate that it was perhaps personal relationships that made interaction more complicated in these cities or that left-wing groups had other spaces they preferred to use in Auckland and Wellington.

In 1975 Suggate left Resistance and the shop was subsequently managed by Andrew Dodsworth, who reduced the amount of Marxist stock and steered the shop in more of

\footnotetext{
139 ibid.

${ }^{140}$ Graeme Minchin to Richard Suggate, c.December 1974, private collection of Richard Suggate.

${ }^{141}$ Thorley, 1975, p.22.
} 
an anarchist direction. ${ }^{142}$ Despite the new premises, meeting space and an extensive range of publications, the shop struggled to survive and was consequently merged with Liberation Books in late 1976. The house at 144 Willis Street was demolished and the site was redeveloped in 1977. The tradition of 'radical' bookselling would be carried on in Wellington though various incarnations in the 1980s and 1990s including the Women's Place bookshop, the NORML Bookshop and the Freedom Shop. However, with the possible exception of the Women's Place bookshop, none would be part of the same kind of nationwide political momentum that had existed from the late 1960s to the mid 1970s. Despite the problems of money and a lack of interaction between the various left factions in the city, the bookshop played an important role in making radical and left wing information available. Education is an essential component in changing attitudes and Richard Suggate later credited the shop with being part of the wider move to break up cultural taboos in New Zealand. ${ }^{143}$ While it is not possible to substantiate Suggate's remark, it can be argued that by making texts available that challenged conventional attitudes about topics like sexual relationships and gender roles, the bookshop was participating within the wider 'radical space' which challenged such conventions.

\section{Christchurch Resistance Bookshop}

The only long-term cooperative bookshop to open in the South Island during the 1970s was the Resistance Bookshop and Action Centre in Christchurch. After reportedly taking two years to be set up, a location at 9 Ferry Road was leased. The premises had previously been leased to the Values Party who used it during the 1972 election. It consisted of three adjoining shops and a warehouse totalling 2,000 square feet and was rented for $\$ 20$ per week. ${ }^{144}$ A group of enthusiasts worked from late November 1972 to set the shop up, painting it, putting up shelves and getting it into a condition to open two weeks later in December. The shop's frontage is shown in figure 19. This shop was run quite differently from the other two. There was no share system like in Wellington and Auckland, rather the shop relied on donations and book sales to pay the weekly rent. There were plans to register the shop under the Industrial

\footnotetext{
${ }^{142}$ Suggate interview.

143 ibid.

${ }^{144}$ Tony Currie, correspondence 4 February 2007; 'Resistance', Ferret, Issue 2, February 1973, pp.189.
} 
and Provident Societies Act 1908 but there is no evidence that this actually occurred..$^{145}$

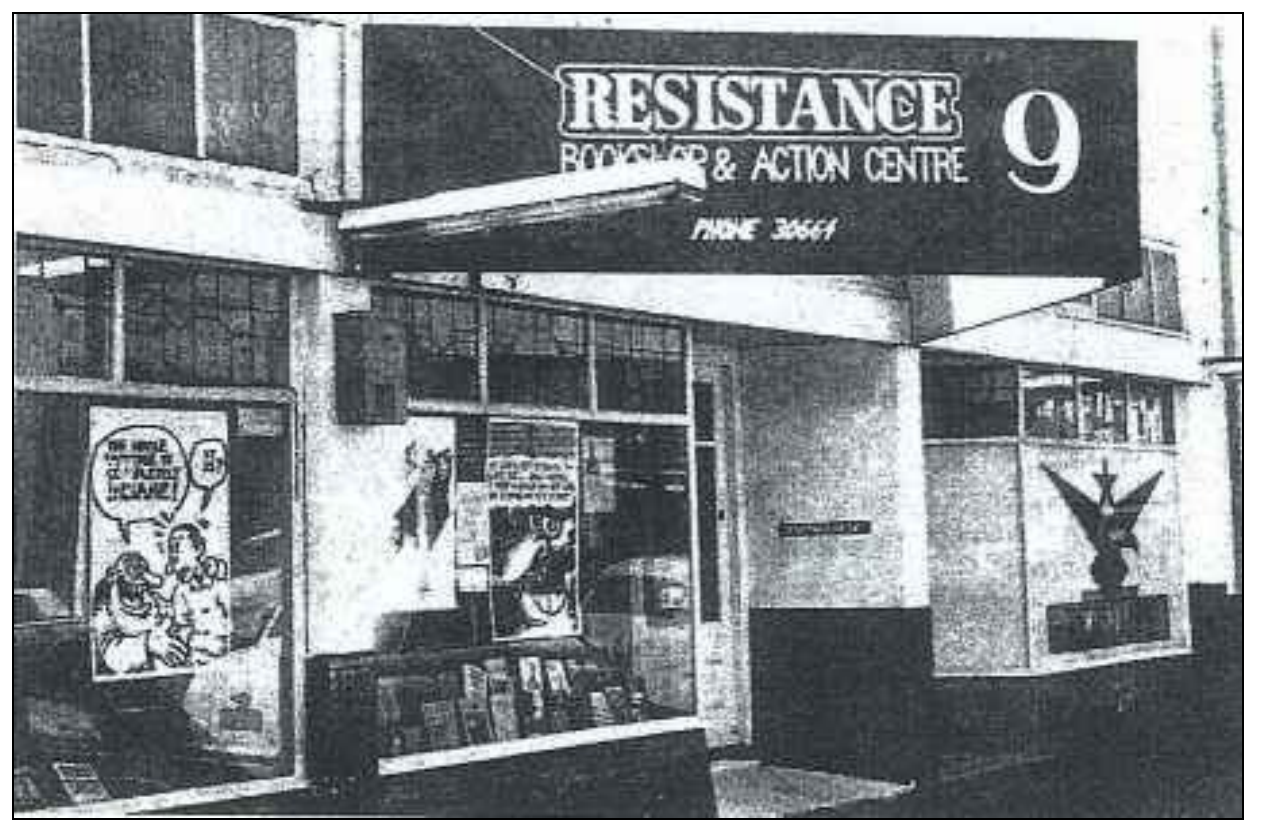

Figure 19 - The exterior of Resistance in Christchurch, 'Resistance', Ferret, February 1973, p.18.

As with Auckland and Wellington, Resistance in Christchurch was run as a collective but the overall managing was done by a shop manager. The collective structure of the shop meant that all the jobs were broken down into a number of positions, thus sharing the load. These positions included shop coordinator, coordinator of the action centre, book ordering and stock taker, finance and budgeter, mail sorter and letter writer, and advertising/designer. ${ }^{146}$ People committed at various levels to the shop and quite often much of the responsibility was left to the shop manager who had the task of ensuring that the shop was functioning as well as possible. Tony Currie and Brian Rooney, both ex-members of the PYM in Christchurch, were long-term shop managers. There is little detail available about payments to staff. Canta reported in 1974 that the shop manager received a "token weekly wage" but this is likely to have been a very small amount. ${ }^{147}$ The shop's printery also did not pay those assisting with

\footnotetext{
${ }^{145}$ Assistance, 14 November 1973, p.1, TFML, Box 1, Folder 3.

${ }^{146}$ Assistance, April 1973, p.1, TFML, Box 1, Folder 3.

147 'Cops Convicted: Resistance Wins Legal Battle', Canta, University of Canterbury, No.12, 27 June 1975, pp.16-7.
} 
production, rather if a job was received from an affluent customer like the University an occasional payment may have been made. ${ }^{148}$

The bookshop stocked similar publications to Auckland and Wellington, generally ranging from Marxist, New Left, feminist and countercultural works through to fiction. The shop also stocked magazines imported from North America like the Georgia Strait, Vanguard, and Black Panther and Native American papers, and they also sold a range of international pamphlets on trade union topics. ${ }^{149}$ Christchurch placed their own international orders and these often took up to three months to arrive. Bulk ordering was often done with the shop even ordering $\$ 1000$ worth of books from Book People at one point. ${ }^{150}$ For convenience sake, the Christchurch shop told Book People that they were a branch of the Wellington shop. ${ }^{151}$ As the shop developed and different people became involved, the type of publications that were stocked became an issue. During a meeting in 1975 it was decided that the shop would "concentrate almost exclusively on political books...it was almost unanimously felt that glossy 'counterculture' books are a rip off and self-defeating to boot". ${ }^{152}$ This 'anti-counterculture' backlash presented itself throughout the country. Claims that the counterculture was apolitical and merely a distraction from 'serious' attempts for a revolution were prevalent and the shop's shelves began to reflect this attitude.

This divide over what material should be stocked by the bookshop represented the greater divide that existed within radical circles. There were diverging attitudes over what was political. For some overthrowing the capitalist system was the main objective, while others were more concerned with the 'cultural revolution' that was occurring through music, film, print and fashion. For a time the counterculture was very fashionable; this meant attracting people to the shop was easier and the associated books were very popular and sold well. While people interested in the

\footnotetext{
${ }^{148}$ Braithwaite interview.

${ }^{149}$ Assistance, 20 February 1974, p.1, TFML, Box 1, Folder 3; Assistance, Vol.2, No.7, p.3, TFML, Box 1, Folder 3.

${ }^{150}$ International orders were paid for after the goods had been received. Further discussion on the bookshops acquiring stock is found on pages 113-4. Tony Currie to Richard Suggate, undated, TFML, Box 1, Folder 3.

${ }^{151}$ Brian Rooney to Richard Suggate, undated, TFML, Box 1, Folder 3.

${ }^{152}$ Meeting reported in: Assistance, March 1975, p.3, Jack Locke Papers: Resistance Bookshop, MBL 116 Box 7, MBL, Christchurch.
} 
counterculture were using the shop, this did not necessarily transfer to a serious interest in left-wing politics. Currie recalled his realisation and disappointment that "countercultural people were actually not interested in politics". ${ }^{153}$ This meant that they were unlikely to contribute to political discussions and campaigning, which was fundamentally what those running Resistance were concerned with. An advertisement for Resistance is shown in figure 20; it represents the iconoclastic and confronting stance that the shop sometimes took.

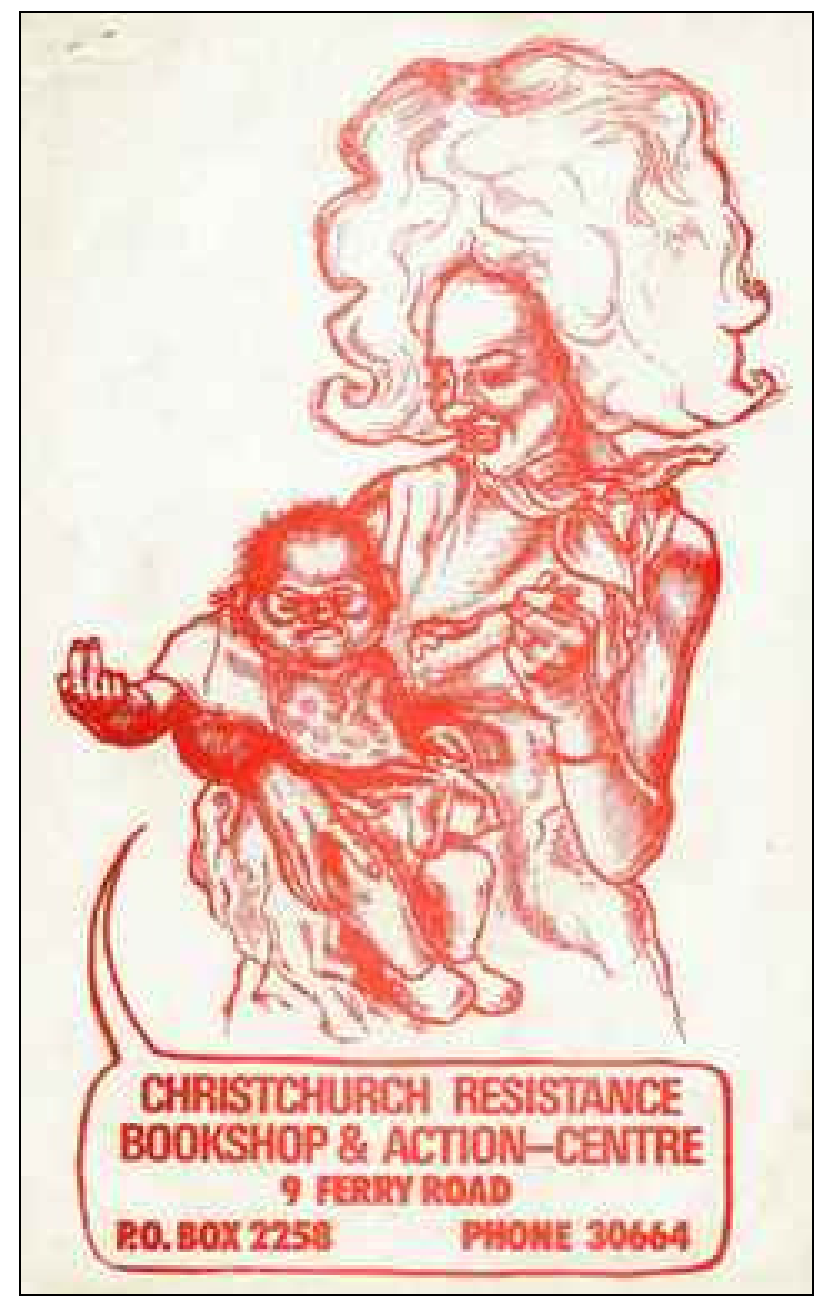

Figure 20 - Advertisement for Resistance Christchurch, Ron Currie, undated, TFML, Box 1, Folder 4

There were other bookshops where people could acquire left-wing and 'lifestyle' publications in Christchurch. These included the Co-op Bookshop in New Regent Street and Pisces Books on Fendalton Road. ${ }^{154}$ The Co-op Bookshop was seen by the

\footnotetext{
153 Tony Currie, correspondence 4 February 2007.

${ }^{154}$ Access 2: directory of movement organisations, c.1972, TFML, Box 1, Folder 3.
} 
city's young radicals as being aligned with the 'Old Left' and the establishment of the Resistance Bookshop, which stocked a great deal of New Left material, represented another generation of the active left in Christchurch. On recalling the differences between Resistance and Co-op Books, Marty Braithwaite distinguished between the two spaces by arguing that "Co-op Books was definitely simply just a Communist Party machine, whereas this [Resistance] attracted some anarchists, communists of various shapes and forms, counterculture type people but the core of Resistance's purpose was as an action centre, the food cooperative, the printery...the whole conglomerate". ${ }^{155}$ While there were some overlaps in terms of Marxist literature between the two shops, Braithwaite, Horton and Bill Rosenberg, who was also involved with Resistance in Christchurch, all emphasised that there was no tension with Co-op Books. ${ }^{156}$ The bookshops were not seen as competing for customers, the “sort of people who came to Resistance wouldn't go to Co-op, it was very much a generational thing". ${ }^{157}$

From the outset, Resistance in Christchurch was set up as a multifunctional space; the bookshop, printery and coordination centre were all established from the beginning but they also planned to set up a food cooperative, a cooperative mechanical workshop, a directory of crash pads and ongoing communication with youth groups. ${ }^{158}$ An advertisement promoting the shop's facilities is shown in figure 21. The action centre aspect of Resistance enabled groups to organise meetings, it was a space where people could display posters and leaflets and overall it aimed to bring people together to "cooperate to build a strong movement in Christchurch". ${ }^{159}$ Tony Currie, who was a long term shop manager in Christchurch, recalled that "some of the Gay Liberation activists taunted the SHE people...that alliance didn't last long. But they were there for a crucial few weeks, until they realised that they needed their own space". ${ }^{160}$ The shop held weekly meetings on a Friday night and brought in external speakers in an attempt to "keep people who are involved with the shop aware of what is going on with other groups", and to ensure that the group did not "develop into a clique". ${ }^{161}$ These

\footnotetext{
${ }^{155}$ Braithwaite interview.

${ }^{156}$ Braithwaite, Horton and Rosenberg interviews.

${ }^{157}$ Horton interview.

158 'Resistance', Ferret, Issue 2, February 1973, p.18.

159 ibid., p. 19.

${ }^{160}$ Tony Currie, correspondence 8 August 2006.

161 Tony Currie to Richard Suggate, 30 November 1973, TFML, Box 1, Folder 3.
} 
meetings often included speakers from a range of groups including SHE and CAFMANZ, it was even planned to have Wes Cameron from the Meat Workers Union speak at one point. ${ }^{162}$ It also ran a Marxist study group; the importance of this was reaffirmed after the 1974 national conference. The Christchurch bookshop decided that education was an important component of its role and the study group would allow people to gain a greater understanding about the political climate in New Zealand, principles of organisation and discuss political ideas. ${ }^{163}$ Aside from these more 'formal' meetings, the meeting space was used by individual groups and was used to paint placards for demonstrations. In terms of fostering communication and awareness between groups, a wall calendar of meetings and contact details was maintained by the shop and the shop's newsletters also included possible 'crash pads' for those needing a place to stay.

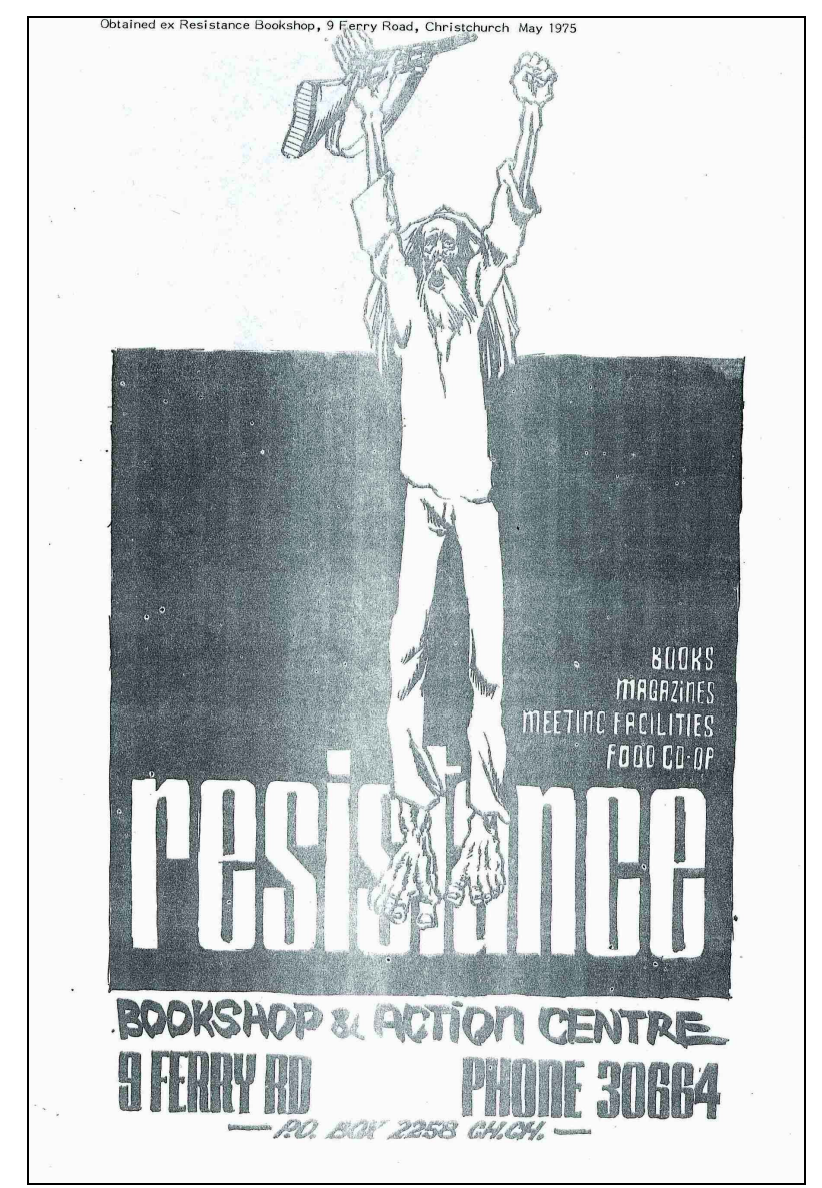

Figure 21 - Advertisement for Christchurch Resistance Bookshop, Ron Currie, 1975, Eph-B-ROTHResistance, ATL, Wellington.

\footnotetext{
162 There is no evidence that Cameron actually spoke at the Action Centre.

${ }^{163}$ Assistance, 20 February 1974, p.3, TFML, Box 1, Folder 3.
} 
The food cooperative was a major part of Christchurch's operation, it began shortly after the bookshop was actually opened and continued to function until the centre closed in late 1976. Individuals had paid \$5 to start their account, the food purchased would then be deducted and they would have to ensure that they continued to top up their account as needed. ${ }^{164}$ Fruit, vegetables, cheese, granola and Chinese black tea were available in whatever quantities were required. Being involved in the food cooperative meant that people also needed to volunteer their time to take orders, transport, sort and box the produce; this could be at times problematic as some people did not pull their weight, but on a whole the system worked well. ${ }^{165}$ The food cooperative was a vital function for Resistance because it was seen as being "part of a greater struggle against a whole system". ${ }^{166}$ It removed people from operating within the capitalist, profit-based food market and gave them an opportunity to experience a cooperative system. The food cooperative was a popular part of the centre, with approximately 150 people involved with it in $1973 .{ }^{167}$ This grew to over 200 people in 1976. ${ }^{168}$ Due to the size of the operation, Resistance even requested donations to buy a $\$ 400$ truck to make the transport of the goods easier. ${ }^{169}$ The success of this food cooperative was rivalled only by the very efficient food programme organised by the People's Union in Auckland, which at its peak was thought to provide food for over 300 households during the 1970 s. ${ }^{170}$

Kozmik Krumbia was the printing arm of Resistance in Christchurch. Run by Marty Braithwaite, the operation printed a range of material including Ferret, shop newsletters, leaflets, pamphlets, letterheads for political groups and student publications including the University of Canterbury's Goldfish. Financially, the printing side of Resistance was separate from the rest of the centre and Kozmik Krumbia was registered as a limited liability company, a compulsory requirement for

\footnotetext{
164 'What is the Resistance Food Co-Operative?', Christchurch Resistance Bookshop and Action Centre Newsletter, c. January 1976, p.1, Eph-B-ROTH-Resistance, ATL, Wellington.

${ }^{165}$ Rosenberg interview.

166 'What is the Resistance Food Co-Operative? Christchurch Resistance Bookshop and Action centre Newsletter, c. January 1976, p.1, Eph-B-ROTH-Resistance, ATL, Wellington.

${ }^{167}$ Assistance, Easter 1973, p.1, TFML, Box 1, Folder 4

${ }^{168}$ Assistance, November c.1976, TFML, Box 1, Folder 4

${ }^{169}$ Assistance, April 1973, p.2 and March 1976, p.1, Resistance Papers, Christchurch 1963-1987, Deposited by David Young, Central 316 Reference ANZC Archives, Christchurch City Library.

170 'Direct Action in Local Struggles - Report on P.U. Programmes', p.10.
} 
companies wanting to open a cheque account. ${ }^{171}$ Braithwaite recalled that the press used "had been the Cock printing press [which was bought by a small group]... then there was the idea of getting the bookshop going so we basically just combined the two although they ran as separate entities". ${ }^{172}$ Kozmik Krumbia was run as professionally as possible; the printery was separate from the bookshop and was locked when not in use to ensure that the equipment was not damaged by people without the skills to use it. ${ }^{173}$ The interior of the printery is shown in figure 22.

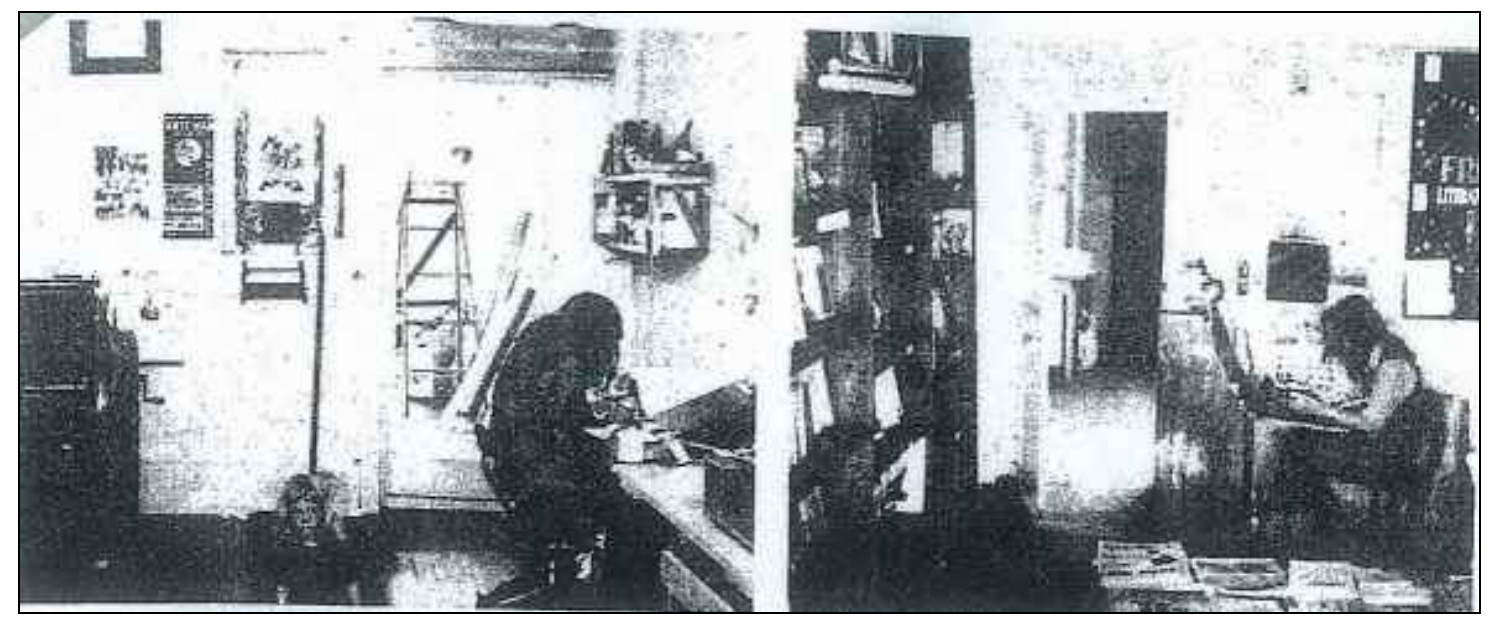

Figure 22 - Inside the printery at Resistance in Christchurch, 'Resistance', Ferret, February 1973, p.19.

The printery was run primarily by Braithwaite and Ron Currie, who was also responsible for the design and advertising of the shop and action centre. Currie and Braithwaite would carry out most of the manual labour associated with production. Aspects like layout, plate making and actually using the press were carried out by the two but if there were large jobs to be collated other volunteers would often be brought in to assist with folding and stapling. There was no profit made from the printery; production was charged at cost price and usually the cost of labour was not charged at all. ${ }^{174}$ The only times that there would be a slightly bigger mark up was if the printing was being done for an organisation like the University of Canterbury Student Association, who had the means to pay more than the average left-wing group. The printing arm was stronger at Resistance in Christchurch than at the other two shops.

\footnotetext{
${ }^{171}$ Assistance, 14 November 1973, p.1, TFML, Box 1, Folder 3.

${ }^{172}$ Braithwaite interview.

173 ibid.

174 ibid.
} 
This can mainly be attributed to Braithwaite's involvement as he had a strong interest in print production and the skills to maintain the equipment.

The most high scale production to come out of Kozmik Krumbia was Ferret, a magazine that was in a similar vein to Cock and Earwig. Braithwaite had been a long time reader of Cock, subscribing to it as a secondary school student while living in the Hawke's Bay. ${ }^{175}$ His early contact with Cock indicates that the distribution of these types of publications was not confined solely to the main cities. After setting up Kozmik Krumbia and the bookshop, Braithwaite produced the first edition of Ferret in February 1973. 950 copies were printed and it contained poetry, articles on various topics like the US military presence in Christchurch, an advert for Resistance and the controversial 'Mad Bombers Handbook'. ${ }^{176}$ The publication of this article prompted the first of many police raids on Resistance in Christchurch. On 27 March 1973, just over three months after the shop had opened, the police searched the premises under a warrant that claimed that the publication Ferret encouraged disorder, violence and lawlessness. ${ }^{177}$ The warrant referred to the article entitled the "Mad Bombers Handbook' which gave instructions about how to make Molotov cocktails, smoke bombs and gelignite. The police spent ninety minutes searching the premises taking away Kozmik Krumbia's files, accounts, a broken electric type writer, copies of Cock and Earwig and Braithwaite's personal insurance papers. But they left alone the actual printing press, Gestetner and plate making equipment. ${ }^{178}$ A special edition of Ferret was published on the raid including a photograph of the police searching the printery, as shown in figure 23. The raid was in some ways beneficial for Resistance as both NZBC and Christchurch Star reporters and photographers had assembled outside the shop during the search and it resulted in major publicity for both the bookshop and Ferret. However, Braithwaite was charged and later convicted under s34 of the Police Offences Amendment Act 1967 with inciting violence. Before his conviction, Braithwaite had claimed that the raid was "merely another example of the repression of left wing movements and the underground press in New Zealand". 179

\footnotetext{
${ }^{175}$ Braithwaite interview.

176 'Our Court Reporter Fined On Mad Bomber Charge', Canta, University of Canterbury, No. 2, 25 February 1974, pp.1-2; Ferret, Issue 2, February 1973, pp.6-7.

177 'The Regime Strikes', Ferret Special, c. June 1973, TFML, Box 1, Folder 3.

${ }^{178}$ Marty Braithwaite, 'Raid's Here', Ferret, Issue 3, May 1973, p.2.

179 ibid.
} 


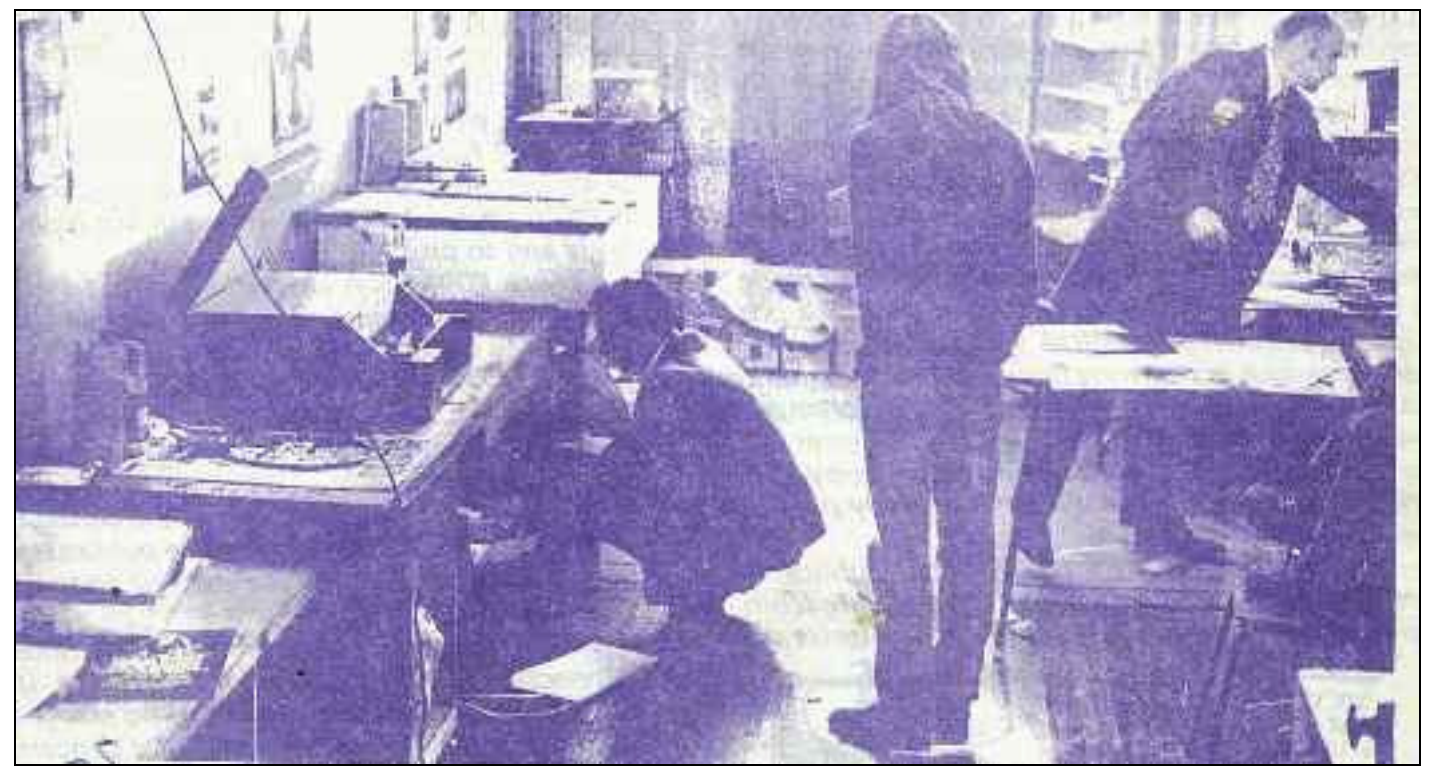

Figure 23 - Marty Braithwaite watching Kozmik Krumbia being searched, 'Ferret Special, c. June 1973, p.2, TFML, Box 1, Folder 3

Police attention was not restricted to the activities of Kozmik Krumbia. Rosenberg recalled that Resistance "was kind of seen by the police as a hotbed of radical action and they had to keep a kind of good eye on it". ${ }^{180}$ Police officers would often enter the shop in an attempt to gain information about future demonstrations. For instance a newsletter reported that "two detectives came into the shop last week on a "social visit' to find out what we had planned for the games". ${ }^{181}$ These casual visits were not always uneventful; and one escalated into a court battle. On 22 February 1974 two plain clothed detectives entered Resistance intending to determine how many people from Christchurch would be attending a demonstration at an ANZUS Council meeting in Wellington. ${ }^{182}$ One was recognised as a detective but after they both refused to identify themselves, they were asked several times to leave before being physically evicted from the shop. The matter was pursued to the point of legal action, where the court case generated a great amount of media attention and both officers were later convicted under the Trespass Act 1968. Resistance pursued the issue because police refused to cooperate and identify the two detectives; this was viewed as an obstruction of justice and the conviction of the two detectives proved to those involved that the “State and its agencies aren't invincible; people can control their own destiny, but

\footnotetext{
${ }^{180}$ Rosenberg interview.

181 The Commonwealth Games were held in Christchurch in 1974. Assistance, 16 January 1974, p.3, TFML, Box 1, Folder 3.

182 'Cops Convicted: Resistance Wins Legal Battle', Canta, University of Canterbury, No.12, 27 June 1975, pp.16-7.
} 
they have to fight it". ${ }^{183}$

One consequence that the court case had for Resistance was the \$200 legal bill that was owed to lawyer Stephen Erber in 1975. ${ }^{184}$ The bookshop "had always had about $\$ 1000$ debts" and it did struggle to pay the rent so this legal bill added to the fundraising burden. ${ }^{185}$ Financial details for Christchurch Resistance are relatively scarce. Unlike the Wellington shop monthly accounts, the Christchurch accounts were not included in its newsletters, which has made assessing the financial position difficult. The financial details that were included covered items like the average amount of stock sold per week; for example in November 1973 the average weekly sales amounted to $\$ 105.00$ and subsequently rose in January 1974 to $\$ 142.50$ per week. ${ }^{186}$ In 1975 Christchurch Resistance borrowed \$1300 to pay overseas book bills so while the finances did not seem as dismal as in Wellington, Christchurch still faced the same problem of finding enough money to pay the rent, order books and keep the centre going. ${ }^{187}$ Currie commented that the bookshop never paid any taxes and the bookkeeping for the shop was "very very primitive". ${ }^{188}$ Another burden for the shop was window breakages, which were a common occurrence. In Easter 1973 it was reported that two large windows were broken on the weekend of the Harewood/Weedons demonstration; a jumble sale was subsequently held to replace them. ${ }^{189}$ However, further damage was reported to Wellington in 1974 when Ron Currie wrote: "We had another window smashed a few weeks ago (the $3^{\text {rd }}$ one), the tool used seemed to be a hammer of some kind but we've got insurance", ${ }^{190}$ The shop had to get grilles to put over the windows at night; fortunately the shop was covered by the landlord's insurance. ${ }^{191}$

Christchurch was a unique city in the sense that people seemed to be able to work together and interact in the same space regardless of their political views. Rosenberg

\footnotetext{
183 ibid.

184 ibid.

${ }^{185}$ Assistance, 27 March 1974, p.1, TFML, Box 1, Folder 3.

${ }^{186}$ Assistance, 30 January 1974, p.1, TFML, Box 1, Folder 3; Tony Currie to Richard Suggate, 30 November 1973, TFML, Box 1, Folder 3.

${ }^{187}$ Assistance, June 1975, p.1, TFML, Box 1, Folder 3.

188 Tony Currie, correspondence 4 February 2007.

${ }^{189}$ Assistance, April 1973, p.1, TFML, Box 1, Folder 3.

${ }^{190}$ Ron Currie to Richard Suggate, 11 May 1974, TFML, Box 1, Folder 3.

${ }^{191}$ Braithwaite interview.
} 
argued that this was "something to do with Christchurch culture...we had quite a broad range of political views there ... people who might have quite different views on the left in general but did actually work together quite well". ${ }^{192}$ When asked about cooperation between political groups, all interviewees from Christchurch offered a similar sentiment. One can speculate that had the question been asked thirty years earlier that there might have been a less 'harmonious' picture painted of the scene in Christchurch. However, what is important to stress is that all interviewees individually emphasised this point, they all recalled that groups interacted and worked together. This contrasted greatly with left-wing groups in Auckland and Wellington. Resistance in those cities struggled to overcome sectarianism. Interaction between groups tended not to happen and attempts by these two spaces to foster it were largely unsuccessful. The tensions that did exist within the Christchurch Resistance Bookshop were focussed around "silly things that people did rather than deep-seated sort of factions or philosophical differences", which could stunt the progress of the bookshop and action centre. ${ }^{193}$ Many of the individuals who had an association with the shop were also highly involved with specific political groups; this was particularly apparent with CAFMANZ, as individuals like Owen Wilkes, Murray Horton and Bill Rosenberg were all heavily involved with both the anti-bases group and setting up Resistance. This provided a direct link between political activity in the city and the bookshop, thus ensuring that Resistance did not become isolated from what was occurring politically.

The close connection with the active left in the city meant that from time to time the bookshop was associated with radical and illegal actions. In 1973, Neil Reithmuller, an Australian student living in Christchurch, became involved with Resistance. He assisted with the food cooperative but soon became disillusioned with the place, believing that it "moved too slowly and no decisions were made". ${ }^{194}$ Reithmuller and his girlfriend Marg Matheson gained national attention on 14 August 1973, when they set fire to the American Consulate on the corner of Kilmore and Manchester Street "as a protest against both capitalism and imperialism". ${ }^{195}$ The pair had broken into the Consulate, doused the place in petrol and set it alight, causing an estimated $\$ 12,000$ of

\footnotetext{
192 Rosenberg interview.

${ }^{193}$ Braithwaite interview.

194 'Mad Bomber Free', Canta, University of Canterbury, Vol.46, No.12, 1976, page unnumbered.

195 ibid.
} 
damage. ${ }^{196}$ They were caught soon after and both were convicted and sentenced to between three and four years in prison. Reithmuller and Matheson were branded as 'political prisoners' by Resistance and support was drummed up for the pair while they were imprisoned, with Christchurch Resistance organising a concert at Reithmuller's prison; they also fundraised to pay for his university fees. ${ }^{197}$ While Reithmuller and Matheson's actions were extreme, they were not isolated as there had already been earlier attacks on government and defence sites in Auckland and Wellington.

In 1974 Canta deemed that Resistance "had consolidated itself economically and politically. It now represents a firm base - a 'unified front', co-ordinated activity centre, meeting place and an information source for its movement". ${ }^{198}$ Resistance was able to maintain its role as an organising base because those involved "organised a lot of political actions and practical activities and things that drew people in". ${ }^{199}$ The individuals involved were collectively active in making Resistance a dynamic and vital part of the active left in the city. This was as important to the space as providing political literature was. The action centre was used to facilitate this activity, to provide a space where people could learn, discuss and carry out political actions. This activity ranged from localised anti-base and anti-war demonstrations through to protests directed at larger scale events like the Commonwealth Games, which was held in Christchurch in 1974. A high profile event that was organised at the action centre was the Resistance Ride, which took place in January 1975. This was a tour organised by Campaign Against Foreign Military Control in New Zealand (CAFCNZ) and comprised of a convoy of protesters touring around the South Island looking at sites like the Comalco Aluminium Smelter in Bluff and the Mt Davy Coal Scheme. ${ }^{200}$ The event was given the name not because it was associated with the bookshop but rather because the term 'resistance' seemed appropriate to CAFCNZ who were organising it. $^{201}$ Promotion for the Resistance Ride was not confined only to those living in

\footnotetext{
${ }^{196}$ Canta, University of Canterbury, No.1, 25 February 1974, p.16.

${ }^{197}$ Braithwaite and Horton interview 20 August 2006; Assistance, 16 January 1974, p.4, TFML, Box 1, Folder 3; Nose 3, Nol.3, Wellington Resistance Bookshop, c. August 1973, p.1, private collection of Richard Suggate.

198 'PYM Commie Resurgence', Canta, University of Canterbury, 14 June 1974, unnumbered.

${ }^{199}$ Rosenberg interview.

200 'Resistance Ride Handbook', CAFCNZ, January 1975', 'Resistance Papers, Christchurch 19631987', Deposited by David Young, Central 316 Reference ANZC Archives, Christchurch City Library. ${ }^{201}$ Rosenberg interview.
} 
Christchurch and those connected with the Resistance Bookshops and CAFCNZ. Organisations like Nga Tamatoa Tuarua in Wellington were also connected with the event. They endorsed CAFCNZ's endeavours to highlight the nature of foreign control in New Zealand and planned to send a delegation on the trip around the South Island. ${ }^{202}$ The purpose of the event was to educate the public about foreign control in New Zealand and this was carried out by visiting and picketing sites, holding public meetings and also staging street theatre at various places. The police "monitored" the group; following them throughout the duration of the tour. This was much to the annoyance of the group who argued that the police presence would give locals the impression that the group were troublemakers - an impression that could be detrimental to the effectiveness of the tour. ${ }^{203}$

The last months that the bookshop and action centre operated in Christchurch saw several substantial changes within the organisation. The shop had begun to lose its place at the forefront of radical activity in the city, with The $2^{\text {nd }}$ NZWEC even reporting that the shop "used to be good, but it is now taken over by the doctrinaire politicos, so its lost its punch". ${ }^{204}$ In April 1976 the shop underwent a name change, becoming the 'Christchurch People's Union', in an attempt to get the community to identify more with the space. ${ }^{205}$ At an organisational level, it was decided to bring together all the operating aspects of Resistance under one coordinating committee: the printery, the food cooperative, the bookshop, the Tenants Protection Association were all brought together under one committee to ensure cohesion within the centre. ${ }^{206}$ However, these attempts to revive the centre were unsuccessful and the shop closed approximately at the end of 1976. Rosenberg recalled towards the end that "the shelves were stocked with these curling paperbacks, bleached by the sun; it was looking pretty depressing really". ${ }^{207}$ Resistance had lost its position within the city as a key organising base, many of the individuals involved with establishing it had left Christchurch and it may no longer have seemed as relevant as it once had. As the

\footnotetext{
${ }^{202}$ There is no record of whether Nga Tamatoa Tuarua actually participated in the ride but the intention was expressed in the Wellington newsletter, Oketopa 1974, TFML, Box 3.

${ }^{203}$ Official Information Act request from Murray Horton to the New Zealand Police regarding the police file on the Resistance Ride, November 1986, private collection of Richard Suggate.

204 'Alternative Bookshops', The 2nd NZWEC, p.353.

${ }^{205}$ Assistance, April 1976, p.2, Jack Locke Papers: Resistance Bookshop, MB 116 Box 7, MBL, Christchurch.

${ }^{206}$ ibid.

${ }^{207}$ Rosenberg interview.
} 
political climate in Christchurch changed so too did the need to have a space operating like the Resistance Bookshop and Action Centre. After the shop closed the stock and debt was transferred to the Co-op Bookshop. This was a controversial decision as the CPNZ largely controlled this bookshop. Despite this, it was agreed that the two bookshops should be consolidated. ${ }^{208}$ Some volunteers from Resistance went on to work at Co-op Books, Currie recalling that their involvement "brought a lot of life to Co-op Books, which had been rather musty and sterile". ${ }^{209}$

\section{Dunedin Resistance Bookshop}

A fourth and very short-lived Resistance Bookshop was also opened in Dunedin in June $1973 .{ }^{210}$ This space differed greatly from the other shops as it was opened in the form of a weekly stall at Mogg's Market at 309 George Street. Otago University student publication Critic reported that the stall would sell books and "endeavour to show a wide range of alternative life styles, contemporary poets, how to survive and live directly from the land". ${ }^{211}$ CCFP publisher Malcolm Gramaphone was instrumental in getting the stall up and running and providing support through his magazine. Dunedin obtained its stock from both the Wellington and Christchurch shops and titles ranged from feminist and Third World liberation texts through to popular fiction like The Electric Kool-Aid Acid Test. ${ }^{212}$ The stall lasted a mere three months; CCFP suggested "perhaps it was started a year too late...after Fat Norm [Prime Minister Norman Kirk] has taken the steam out of the anti-war, anti-tour, anticonscription and other demonstrations". ${ }^{213}$ Its conclusion is debatable, but what is certain however, is that Dunedin faced the same problems that the other three shops faced, just on a much speedier and smaller scale. Problems with staffing, building a customer base and ensuring a regular supply of income were issues that the all

\footnotetext{
${ }^{208}$ Tony Currie, correspondence 4 February 2007.

${ }^{209}$ ibid. During the 1980s there was a change in the type of books that were being stocked by the Co-op Bookshop. No longer was it a purely orthodox left wing bookstore, rather it diversified and began to stock a number of anarchist publications. A number of ex-Resistance associates were involved including Richard Suggate. Co-op Books was the last of the four original cooperative bookshops to close, ceasing operation in 1988.

${ }^{210}$ The Dunedin bookshop has been largely excluded from this thesis because of the stall's temporary set up and short lifespan.

211 'Resistance', Critic, University of Otago, 10 July 1973, page unnumbered.

212 Tony Currie to Richard Suggate, undated, TFML, Box 1, Folder 3; Tom Wolfe, The Electric KoolAid Acid Test, New York, 1968.

213 'Resistance Dunedin', Counter Culture Free Press, No.6, November 1973, Dunedin, p.46.
} 
Resistance Bookshops faced during the 1970s.

The three Resistance Bookshops lasted between four and six years respectively. There are a number of reasons that can be attributed to why the bookshops were relatively short-lived. Firstly, most of the people that were involved were young. When the shops were established many of those involved were in their late teens, early twenties. Some of the same people were still involved towards the end of the shops' operation and naturally wanted to move on to other things. This is particularly in regard to those who held up the managerial side of the shops. This voluntary work required a lot of commitment and replacing these individuals once they left was not easy. Secondly, the shops' finances were a constant struggle. Weekly sales were not high enough to cover amenities and stock payments and as debt grew for each of the bookshops, closure became more certain. The reality was that by the end of the 1970s, aside from the action centre function, the Resistance Bookshops were no longer exceptional. There were other booksellers offering similar stock and activists had other spaces they could use to organise in each city. The political climate was also changing in the late 1970s. For example in Christchurch, Currie recalled that political groups were "heading off in different directions" and therefore did not need a space to work alongside other groups. ${ }^{214}$ With the closure of the bookshop Rosenberg emphasised that “people didn't kind of say 'oh Resistance is gone there's nothing to do' it was really that things just moved on to different forms of organising", ${ }^{215}$ The short term existence of each of the bookshops should not lessen the impact that they made. The fact that each shop was operated as a collective for several years is quite an achievement, particularly as they all had very limited finances and experience in bookselling. Most importantly, the impact that the bookshops made should be drawn from the role that they played within the culture of radical protest and politics. By enabling political and alternative material to circulate, the shops established themselves as a core part of political activity during the 1970s.

Tim Shadbolt suggested that the Resistance Bookshops were "an attempt to compromise revolution and capitalist business". ${ }^{216}$ His assessment was in some ways

\footnotetext{
${ }^{214}$ Tony Currie, correspondence 4 February 2007.

215 Rosenberg interview.

216 'How's the revolution Tim?', Craccum, University of Auckland, 4 March 1974, page unnumbered.
} 
correct; the Resistance Bookshops were an unusual mixture of commercial bookselling, collective management and providing a non-partisan meeting space for political groups. Bookselling, due to its commercial nature, would seem to be the antithesis to the type of left wing politics advocated by those involved but this contradiction was somewhat resolved due to the type of radical material that was being sold. Aside from stocking political texts and local political ephemera, the bookshops were an important expression of the aims and direction of the radical protest culture in New Zealand during the early 1970s. People were keen to explore collective ways of challenging the conventions of mainstream society and the bookshops were a way to show "that people like us [young and radicalised] could have our own business, have bookshop and a printing press and actually do that sort of stuff ourselves". ${ }^{217}$ While the bookshops faced many difficulties due to shrinking customer numbers, limited finances and dwindling public support, the shops were able to achieve a certain level of success, as they played a key part in expanding the type and range of publications that were available in New Zealand during this period. The popularity of books like those written by Abbie Hoffman, Jerry Rubin and the Alister Taylor publications proved that there was a market for such books and showed that readers were interested in countercultural and radical political ideas. The Resistance Bookshops were radical spaces which circulated these titles and perhaps most importantly, they were physical locations which both advocated and carried out some of the principles that were expressed in such books. The role that the shops played in helping to raise consciousness about political issues is central to illustrating how the bookshops supported protest movements active in each city. The Resistance Bookshops ensured that there was a space, run by activists, where political material could be accessed, the ideas that informed the print material could be debated, and ultimately used to help mobilise for political and social change.

${ }^{217}$ Bradford interview. 


\section{Chapter Three \\ Challenging Conventions: The Resistance Bookshops and the role of print in radical politics}

From the late 1960s print became a key part of radical politics in New Zealand. In Wellington an underground magazine provocatively entitled Cock emerged, which ridiculed everyone from the SIS to Muldoon to the Red Cross. Political groups churned out newsletters and leaflets, which could now be produced quickly and cheaply due to duplicating machines. It was the distribution of this type of print, along with the titles being both published in New Zealand and those imported from international sources, that was the core purpose for each of the Resistance Bookshops. This print contained ideas that had the ability to challenge, provoke, and most importantly, mobilise. There was power in the words of Germaine Greer and Eldridge Cleaver and for many the ideas contained in these texts and others, were an important stimulus for participating in radical politics. The following chapter will look at the range and style of underground and alternative print in New Zealand, looking at the processes of production, distribution and linking this body of print with specific campaigns in New Zealand. This discussion will also draw connections with the broader international print culture that developed during the 1960s and explore the increasing role of illustrations and graphics in political print.

The printed material that was being both produced by, and distributed through, the Resistance Bookshops was part of a much larger network of alternative and underground print available in New Zealand in the early 1970s. ${ }^{1}$ The late 1960s until mid-1970s was a distinct period in print culture as it was a time when technological advances collided with the social unrest and protest of the Sixties to create a unique body of work. Many of the books, pamphlets, magazines, cartoons and newspapers produced were closely aligned with the international counterculture and youth movement. A number of these publications captured this social activity through a distinct stylistic approach and thus created a legacy that is represented best through psychedelia, fusions of colour, photography and graphics. The other side to this body

\footnotetext{
${ }^{1}$ The term 'underground' is useful because it suggests that the print in discussion is dissident and in many cases was being produced at a grassroots level. Individuals and groups began self-publishing, utilising technological developments like offset printing and duplicating machines, which made the production of material cheaper and easier than ever before.
} 
of print was a series of more ephemeral publications that were without the aesthetic focus that some underground titles adopted. This could range from the leaflets quickly produced to hand out at demonstrations, to newsletters produced by individual political groups, or notices to be pasted up around town concerning the next major demonstration. These types of publications were produced fast and cheaply and served a distinct purpose, which was to communicate with supporters and get the message out as widely as possible. The Resistance Bookshops were spaces in which this material could be freely circulated.

In this research the terms 'alternative' and 'underground' each represent a type of printed matter, which offered the reader something substantially different from regular or 'mainstream' print sources. Chris Atton, in his discussion of alternative and radical media in Britain and in the United States distinguished between alternative and radical print by defining 'radical' as something that is concerned with social change, while 'alternative' has a more general application. ${ }^{2}$ In this sense, the term alternative media is indicative of a non-mainstream or substitute source of news, information and ideas, while radical is indicative of a more confrontational and revolutionary media source. This definition can be applied to New Zealand print culture, from the 'underground' magazines which provided anti-Establishment rhetoric and widespread societal critiques through to the alternative publications of small publishers like Alister Taylor, who produced titles which appealed to the countercultural market. Self-publishing was often the only means to get ideas out which were absent from mainstream print sources. Tim Shadbolt described the mainstream media in New Zealand as "trivialised, sensation-based propaganda"; while Wheeler of Cock magazine asserted that New Zealand's underground magazine and newspapers "represent the only 'free' press we've got". ${ }^{3}$ While such print production may have only have had small circulation runs or had a limited readership, underground print still had an important role as it got radical ideas and political views out into the public sphere.

\footnotetext{
${ }^{2}$ The terms 'radical' and 'underground' can be interchangeable because they both represent a 'nonmainstream' source of information. Chris Atton, Alternative Media, London, 2002, p.9.

${ }^{3}$ Shadbolt, p.202; 'What Went Wrong', Cock, Issue 17, August 1973, p.3.
} 
The first type of underground print that will be examined can be described as 'social movement journalism', as it was created by individual political groups in New Zealand, which advocated social change. These publications were not controversial like the anti-Establishment magazines and their producers were not subject to police attention. The phrase was coined by Bob Ostertag and refers to the production of movement newspapers which aim to promote ideas and exist to make change, rather than serve business interests, as the mainstream media are required to. ${ }^{4}$ It is a fitting term to describe the type of publishing that individual political groups in New Zealand were engaged in. Often political groups had their own publications that were 'single issue' based and contained articles that were written by members of the organisation or included reproductions of articles from other sources. These articles were included to highlight developments in the campaign, to provide national and international news stories and to give information about future actions that were planned. All of the political groups from New Zealand that were profiled in chapter one published newsletters or newspapers; these were distributed to members through the mail and the public could also obtain them through selective bookshops and from street sellers.

There was an abundance of these publications, many of which sustained a much longer existence than the high production magazines to be discussed later in the chapter. This may be because these publications had an established readership. For example those interested in the anti-apartheid campaign used the HART News as a source of information, the paper therefore had a distinct purpose, which was to aid HART in educating and raising awareness about the anti-apartheid campaign. Magazines like Cock and the Counter Culture Free Press (CCFP) did have an enthusiastic readership but these publications were not part of any specific campaign and were primarily connected with the broader anti-Establishment, youth movement that flourished in the late 1960s and early 1970s. Many of the newsletters produced by political organisations were concerned with the factual substance of the newsletter rather than having an aesthetic focus like countercultural publications. This meant that many, but not all, publications consisted solely of typed text, printed on low-cost paper like newsprint, the publications were churned out quickly and often sold at cost

\footnotetext{
${ }^{4}$ Bob Ostertag, People's Movements: The Journalism of Social Justice Movements, Boston, 2006, p.3.
} 
price. This type of print was very ephemeral, it was about providing detailed information about key issues and distributing it as quickly and as widely as possible. The Resistance Bookshop newsletters were also printed in this form and were produced to communicate to customers, shareholders and associates about new book orders, book reviews, key topical issues and campaigns and anything to do with the shop itself.

During the 1970s there were a great number of 'grassroots' or 'social movement' publications. Leftist groups like the SUP published the NZ Tribune, New Zealand Spartacist League produced the New Zealand Spartacist, while the SAL produced Socialist Action, a Trotskyist newspaper with an international focus. ${ }^{5}$ Trade unions such as the Wellington and Taranaki Drivers Union also published newspapers, in their case, Roadrunner. Each branch of the PYM published their own magazine or newspaper, including Rebel from Auckland, Rabble from Wellington and Rag Tag, Rabble-Rousing Mickey Mouse Stuff from Christchurch. The OHMS published Repeal, a national newsletter that was printed as part of their campaign against compulsory national service. Environmental groups like the Native Forest Action Council published Beechleaves, a tabloid style magazine, while the Chippenham Community in Christchurch produced the New Zealand Environment magazine. Women's groups produced publications including Broadsheet, Circle and Up From Under and the Gay Liberation Front in Auckland produced Gay Liberator. HART published HART News and later Amandla, which discussed the anti-apartheid campaign in New Zealand and internationally, with the first edition of HART News reportedly selling 7000 copies. ${ }^{6}$ The Maori Organisation on Human Rights (MOOHR) published MOOHR Newsletter, which dealt with racial discrimination, while the campaign against foreign control produced the Foreign Control Watchdog. Those interested in alternative lifestyles had Mushroom magazine with which to communicate and share information. ${ }^{7}$ The People's Union in Auckland also produced a bimonthly newspaper, while the paper was a political statement, it was also an important means for the centre to communicate with the community. Each edition contained Samoan, Tongan and Cook Island Maori translations, alongside the English

\footnotetext{
5 'Radical Press in New Zealand', The First NZWEC, pp.250-251.

${ }^{6}$ Richards, p.74.

${ }^{7}$ See the bibliography in Sargent, 2004 for an extensive list of literature on communities during this period.
} 
text to ensure that it was accessible to the multicultural population of Ponsonby/Grey Lynn. Many of these publications were sold by the Resistance Bookshops, who also sold books that were relevant to the issues and campaigns more generally. Figure 24 shows the covers of a selection of these 'grassroots' publications.
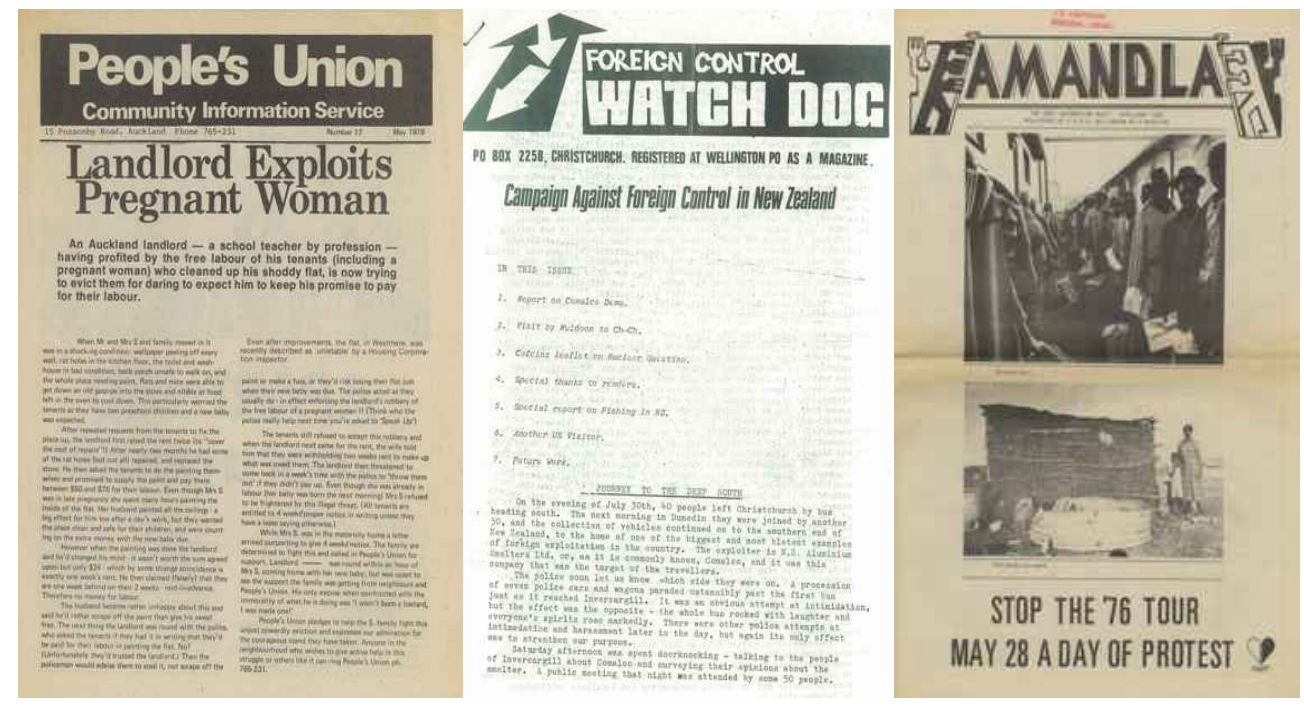

Figure 24 - A selection of publications produced by New Zealand political groups in 1976, TFML, Box 3 .

Occurring concurrently in New Zealand was the emergence of a particular type of print culture which had links with the underground press coming out of the United States during the late 1960s. ${ }^{8}$ The press was a fusion of radical politics, countercultural idealism and aesthetic innovation and many of the major titles were sold in New Zealand by the Resistance Bookshops. In New Zealand a similar print culture emerged, however, it would be inaccurate to refer to the underground printing scene in New Zealand as an 'underground press' as it implies scale and regularity of production that the New Zealand setting did not have. Underground print in New Zealand ranged from the highly stylised and politically charged pages of magazines like Cock through to the more ephemeral plain text newsletters of groups like HART; the Resistance Bookshops helped to distribute both. There had always been publications produced by groups like the Communist Party and trade unions in New

\footnotetext{
${ }^{8}$ There are many accounts of the underground press in the United States during the late 1960s, early 1970s including: David Armstrong, A Trumpet to Arms: Alternative Media in America, Los Angeles, 1981; Robert J. Glessing, The Underground Press in America, Bloomington, 1970; Laurence Leame, The Paper Revolutionaries: The Rise of the Underground Press, New York, 1972; Roger Lewis, Outlaws of America - The Underground Press and its Context: Notes on a Cultural Revolution, London, 1972; Abe Peck, Uncovering the Sixties: The Life and Times of the Underground Press, New York, 1991; Rodger Streitmatter, Voices of Revolution: The Dissident Press in America, New York, 2001.
} 
Zealand but these underground publications produced in the late 1960s, early 1970s, reflected ideas and images that were very much connected to the contemporary era. This print was produced in a variety of forms. The most common was a low-scale magazine or 'zine' format, as they have since come to be known as. These publications were self-published and contained graphics, colour and more generally a greater level of experimentation. The most well-known of the underground New Zealand titles from this period were produced in this magazine format, some titles included Earwig, printed in Auckland, Cock, printed in Wellington, Ferret, printed at Resistance in Christchurch and CCFP, printed in Dunedin. Selected covers for some of these titles are shown in figure 25.

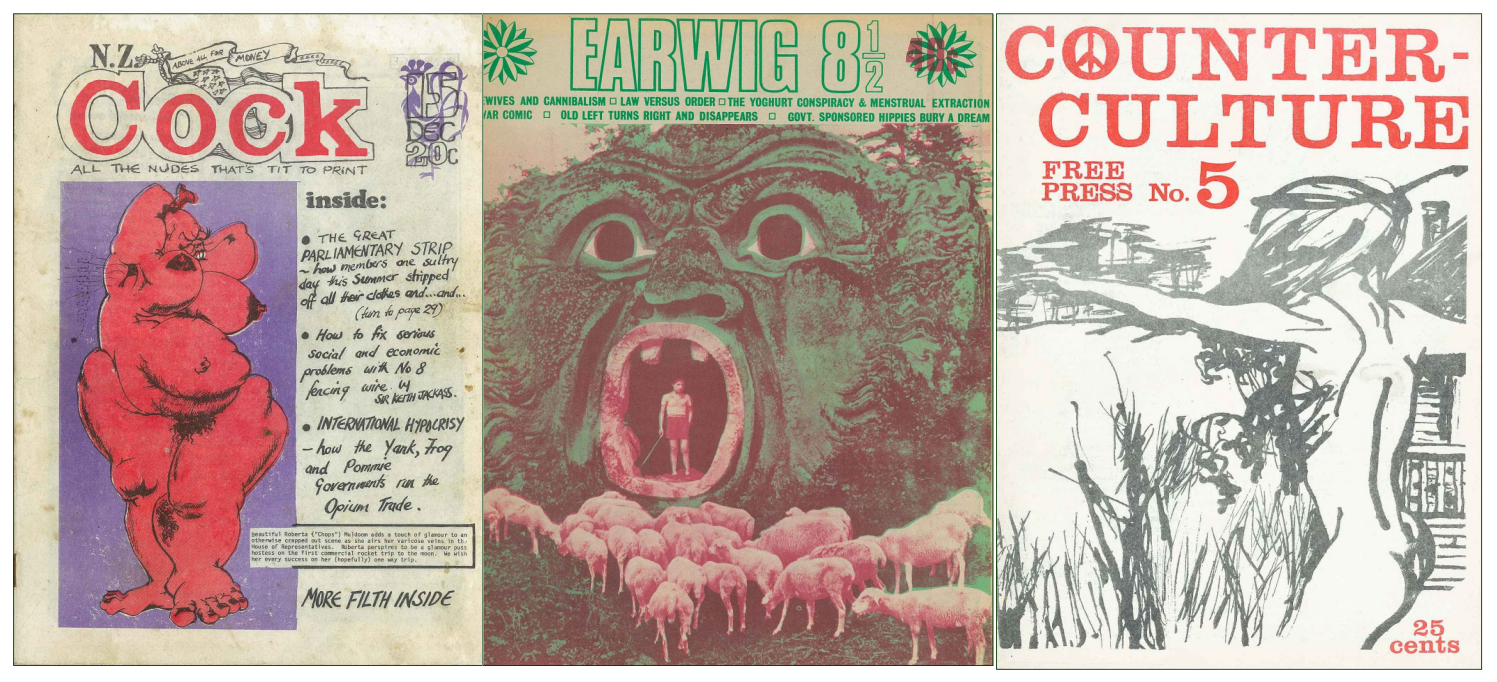

Figure 25 - A selection of covers from three underground magazines, Cock: December 1971; Earwig: c.1973; Counter Culture Free Press: August 1973 TFML, Box 2.

All these titles tended to be a mix of politics, humour and anti-Establishment sentiment. These publications embraced many of the concepts and language that individuals involved with political groups and the counterculture had also adopted. Murray Horton recalled that "there was a whole movement where phrases like 'revolution' were used without quotation marks or to sell shoes". 9 There was a genuine belief that political change was possible and radical young people used the rhetoric of Marxist literature, Third World Liberation movements and the American New Left to convey their conviction that the social change that the 'movement' was advocating could be realised. Much of this rhetoric was also included in underground print but aside from this 'power to the people' type rhetoric, magazines like Cock

\footnotetext{
${ }^{9}$ Horton interview.
} 
relied on headlines and articles which ridiculed and satirised the 'Establishment': headings like "General Erection Proves Bad Taste Popular", referring to the reelection of the National Party in 1969; “The Pornshop Strangler Strikes Again!”, reporting on anti-pornography campaigner Patricia Bartlett, shown in figure 26; and “The pig was mad and short but where did he get his power?", ridiculing Robert Muldoon and his role as Finance Minister. ${ }^{10}$ These headings are characteristic of the type of approach taken by those producing Cock to criticise the 'Establishment' through satire and ridicule.

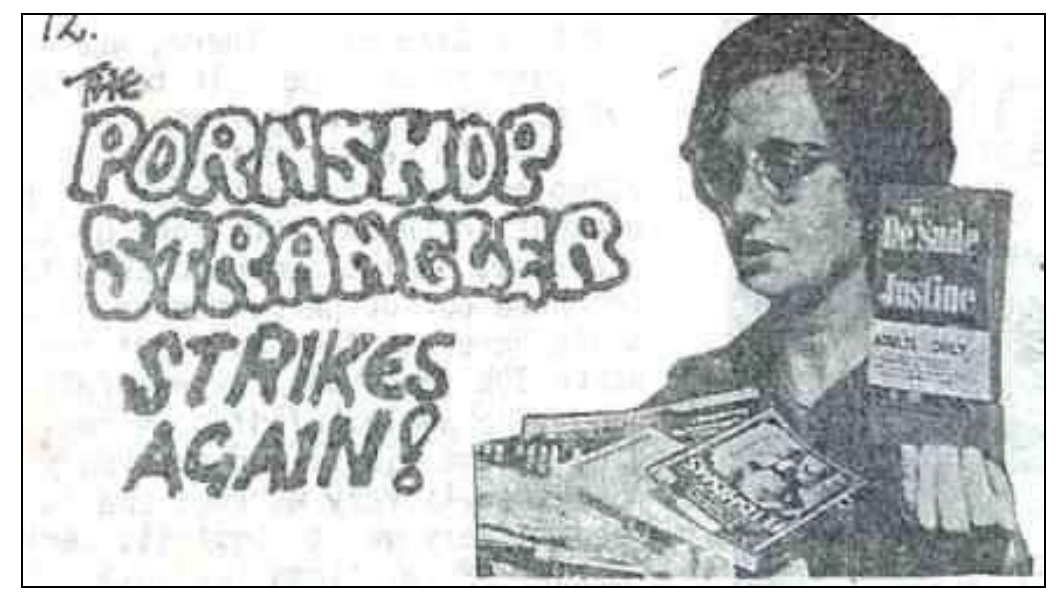

Figure 26 -Patricia Bartlett from the Society for the Promotion of Community Standards was a frequent target for ridicule within the pages of Cock, 'The Pornshop Strangler Strikes Again!', Cock, No 15, December 1971, p.12.

Titles such as Earwig are characteristic of the unconventional stylistic approach which some underground publishers explored during the late 1960s, early 1970s. Publishers and designers challenged conventional attitudes to the layout, design, colour, language, spelling, and content of books and magazines. Some writers shunned orthography, adopting or inventing new forms of spelling as a direct act against orthodox conventions. Some common 'misspellings' included America as 'Amerika' or using \$ signs instead of 's' to represent capitalism, greed, imperialism. Feminists adopted new forms of spelling like 'Womyn' and 'Herstory' to challenge patriarchal conventions. Aesthetically, publishers tested the visual potential of print, changing the colour of ink from page to page, using different typography within volumes, often the design of the page would dictate the actual type, determining the

\footnotetext{
10 'General Erection Proves Bad Taste Popular', Cock, Issue10, December 1968, p.3; 'The Pornshop Strangler Strikes Again!', Cock, Issue15, December 1971; p.12; 'The pig was mad and short but where did he get his power?', Cock, Issue 3, 1968, p.15.
} 
length of articles and how the type was laid out and read. Colourful or psychedelic imagery was often incorporated within the text, changing the way that a reader engaged with a publication. Figure 27 is an example of the type of design and layout that publications like Earwig were experimenting with. Together, the creativity of these stylistic elements represented the revolt and nonconformity of ideas that underground publishers were exploring. They also encompassed the more widespread challenge that the counterculture and youth movement were directing towards 'mainstream' culture.

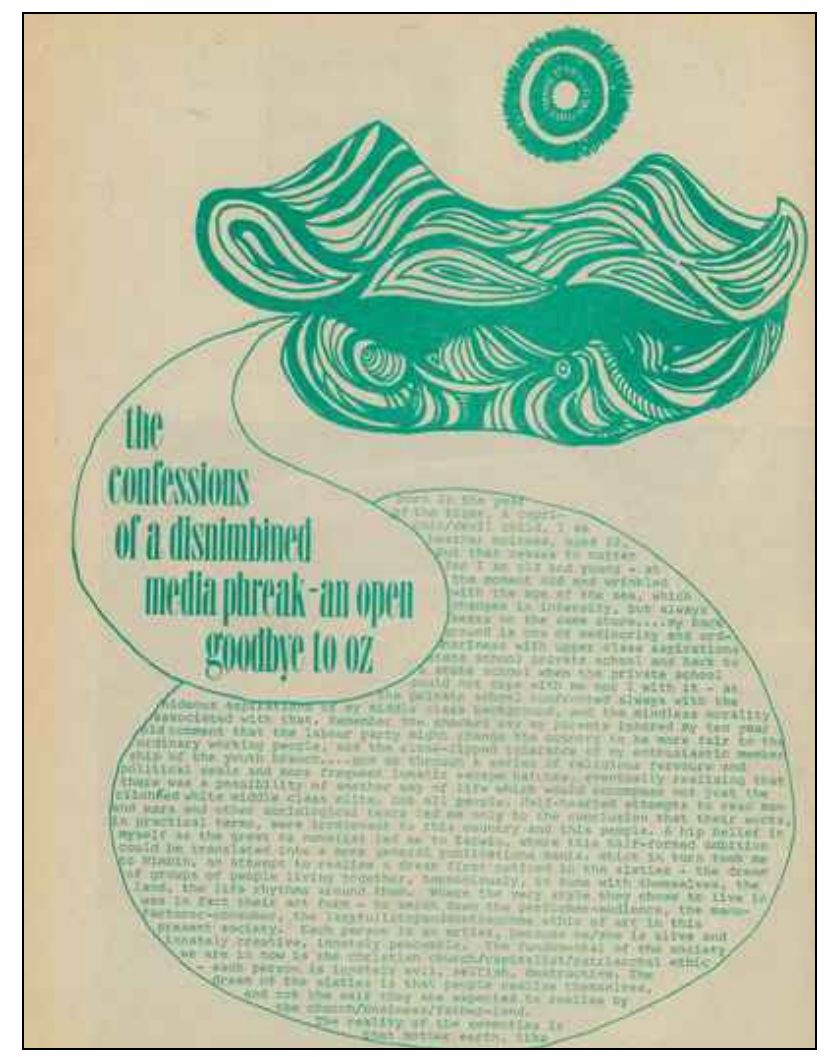

Figure 27 - The unconventional layout of Earwig 8 1/2, c.1972, p.6.

For many of the countercultural publications, the design and graphics became a major focus. Many publications used a mixture of hand drawn graphics, comics and also photographs to supplement the text. Graphics and illustrations became a key way to communicate, an illustration or symbol could represent a position or idea much more quickly than an article or editorial ever could and often by breaching 'good taste' in an image, a point could be made that could have been overlooked in another 
medium. ${ }^{11}$ Publications would use photos or illustrations as focal points for a page, these often dominated the background of a page while the type was overlaid, integrating both written and visual sources. Publications also often included symbols that tended to be universal in their usage. Often the symbolism of the images had links with earlier movements, particularly the clenched or raised fist, an important symbol of resistance and solidarity with a long history within revolutionary movements, having been used in the French and Soviet revolutions and by the Republicans in the Spanish Civil War. ${ }^{12}$ In the late sixties, the fist symbol was adopted by political groups internationally and used both in print and in gesture by members to represent opposition, militancy and unity within the movement. The fist emblem was used to head the letter pages in both CCFP and Craccum, it was even adopted as the emblem for the Auckland Resistance Bookshop. In doing so, the shop was presenting itself as part of this international movement, consciously aligning itself with the radical politics and ideas associated with the New Left and Black Power.

Cartoons and graphics were also an important part of Cock, which had a number of illustrators and graphic artists who contributed to the magazine at various points throughout the six years that the magazine was in print. Brent Wong and Bob Brockie were both major presences within Cock's pages. Wong, a well-known artist, was listed as the designer for the first seven issues of Cock and continued to contribute to it thereafter. Brockie contributed some of the most well-known cartoons that Cock printed, including his illustration of Muldoon in full fascist regalia. ${ }^{13}$ Brockie later became a cartoonist for the National Business Review, producing cartoons for a publication with a markedly different political flavour. Cock also was a platform for other well-known New Zealand cartoonists like Tom Scott, who contributed to the last edition of the magazine in 1973. These illustrators and a large group of other contributors provided graphics and cartoons that critiqued society and the government through satire, parody and humour. ${ }^{14}$ They differed from the political cartoons in

\footnotetext{
${ }^{11}$ Lewis, p.80.

${ }^{12}$ Lincoln Cushing, 'A brief history of the "clenched fist" image', Docs Populi: Documents for the Public, available from http://www.docspopuli.org/articles/Fist.html; accessed 24 March 2006. Republicans are seen raising their fist in solidarity at a meeting during the Spanish Civil War, Joris Ivens, Spanish Earth, Terre d'espagne, 1937.

${ }^{13}$ Cock, Issue 3, 1968, cover page.

${ }^{14}$ For further discussion of the history of comics in New Zealand, see Tim Bollinger, 'Comic Story', New Zealand Listener, 5 August 1995, pp.42-3 and Dylan Horrocks, (ed), Nga Pakiwaituhi o Aotearoa: New Zealand Comics, Revised Edition Auckland, 2000.
} 
mainstream papers firstly, because they were generally left-wing perspectives and secondly, the cartoons tended to be more provocative in their depiction and use of language and imagery. All these aspects appealed to their countercultural or radical readership.

While these titles were relatively well known among young politicised people during the early 1970s, only a limited number of issues were produced for each title. Seventeen issues of Cock were produced over six years, while Earwig and the CCFP produced only eight and seven issues respectively over several years. The assembly of newspapers and magazines was often a painstaking process. Aside from actually writing the columns and articles, Wheeler commented that the assembly of the magazine "took over two weeks of intensive preparation for us to print, fold and staple with voluntary labour leaving aside all the earlier weeks spent collecting and pasting up copy". ${ }^{15}$ Finances were also a major reason that prohibited more frequent production. These magazines contained very little advertising; those that were included were often closely related to the interests of those publishing the magazine, for example advertising that promoted cheap printing facilities or 'progressive' books or magazines. For publications like CCFP and Cock, advertising was free for 'likeminded' organisations or products and it was purely about promotional not revenue generating. Cock encouraged its readers to subscribe, claiming in the last issue ever printed that "Subscribers are the best guarantee of our survival. If we had more of them we'd be more regular". ${ }^{16}$ Publishers had to rely solely on the sales for each issue to keep producing the magazines. Costs were kept as low as possible by printing on cheap paper like newsprint and by using voluntary contributors to the magazine.

In terms of selling underground magazines, the publications were distributed in two ways. The first was through independent booksellers like Resistance or Unity Books in Wellington and through the university bookshops. There was not necessarily a harmonious relationship between those producing underground magazines and those selling them. In an article in Earwig, it was stated that some residents of the Auckland Resistance Bookshop believed that publications like "Cock and Earwig, despite passing on a few scraps of useful gossip, are impotent because they offer nothing for

\footnotetext{
${ }^{15}$ 'What Went Wrong', Cock, Issue 17, August 1973, p.3.

${ }^{16}$ ibid., p. 2 .
} 
people to get their teeth into as a solution.". ${ }^{17}$ Regardless of personal beliefs, the publications were still stocked because they were popular and sold well. The second means of distribution was on a more ad hoc basis; individuals were encouraged to 'push' a magazine, this meant buying a number of copies of the publication and then selling them on the street for a small profit for themselves. People were also encouraged to buy subscriptions, this meant that issues would be individually mailed. If a publication was registered with the Post Office, cheap bulk postage rates could be granted, however the Post Office could decline registration if the publication was found to be unsuitable. Several New Zealand titles were also involved with the Underground Press Syndicate (UPS), which was an international network of underground publications that linked over 230 papers. ${ }^{18}$ Being involved in the syndicate meant that there was a possibility for international circulation and publications were able to reproduce articles and cartoons from other UPS titles. Earwig praised the UPS for being a "stockpile of good graphix [sic] and articles when you're going through the heavy birth pains", meaning that they were an invaluable aid for those groups establishing an underground paper. ${ }^{19}$

Most underground publishers did not have their own printing press, but finding a printer that would agree to produce radical print was not always easy. Student publications like Victoria University's Salient, while not 'underground', as it was funded by an institution, faced some of the same problems as other underground publishers because they too were producing political and at times provocative material. Salient was written and 'pasted-up' on campus and then transported to Wanganui to be printed by registered printers. Underground publications like Earwig also used commercial printers, in their case in Morrinsville in the Waikato, 100 kilometres from their Auckland premises. ${ }^{20}$ But such arrangement could still be problematic because printers were legally liable for the material that they were printing. ${ }^{21}$ Occasionally articles were covered up or removed due to their offensive

\footnotetext{
17 'Old Boy's Notes; 1', Earwig, Issue 81/2, p.12.

${ }^{18}$ Lewis, pp.179-191.

${ }^{19}$ Earwig, Issue 6, c.1972, p.43.

${ }^{20}$ East Waikato Publishers Ltd, Morrinsville, printed in Earwig, Issue 3, p.3.

${ }^{21}$ Under the Newspapers and Printers Act 1955 printers needed to be registered at the High Court. Previously all printing presses had to also be registered, however, this requirement was dropped with the 1955 Act. For further information on government printing regulations see Penny Griffith, Ross Harvey, and Keith Maslen (eds), Book and Print in New Zealand: A Guide to Print Culture in Aotearoa, Wellington, 1997, p.81.
} 
language or inappropriate content, at the discretion of the printer. ${ }^{22}$ This situation led to some individuals and groups purchasing their own printing presses. Private or small presses were used to produce newspapers, magazines, and collections of poetry or literature. Wheeler established the Cockerel Press "after thirty printers in Wellington refused to print his material, which involved an obsession with the SIS and haunting its headquarters at 175 Taranaki Street.". ${ }^{23}$ This meant that Wheeler was able to selfpublish Cock and he also had the freedom to venture into other avenues of print, for example the larger scale children's book he published entitled Little Big Mouth - The Story of a Little Girl Who Became Prime Minister, and a series of Vietnam War themed Christmas cards, which were sold by Resistance in Wellington for five cents each. $^{24}$

The difficulties involved in finding an accommodating printer was not the only problem the underground publishers faced. Rather, government legislation also impacted on these publishers, many of whom struggled with the issue of freedom of the press. In an article in the First New Zealand Whole Earth Catalogue (NZWEC), Wheeler stressed the problems that New Zealand publishers faced by stating that readers should "have a look at the Printers Act, the Crimes Act, the Police Offences Act, the Indecent Publications Act... if you still believe that New Zealand has freedom of the press and freedom of speech after reading them you should join the police force or become a politician". ${ }^{25}$ As discussed in chapter two, Itch, a magazine produced at Wellington Resistance and Ferret produced at Christchurch Resistance both received police attention due to their provocative content. As their content was considered to have violated legislation, the places in which they were produced were raided by the police, in both cases the magazines were printed in the Resistance Bookshop's printing rooms. The case against Itch was brought under the Indecent Publications Act 1963 and it was declared indecent by the Indecent Publications

\footnotetext{
${ }^{22}$ In 1973, Salient was subject to censorship imposed by their printers, Wanganui newspapers. Stephen Hamilton, A Radical Tradition: A History of the Victoria University of Wellington Students' Association, 1899-1999, Wellington, 2002, p.167.

${ }^{23}$ Brunton, 1997, p.19.

${ }^{24}$ Cockerel Press Christmas cards are located in the Jack Locke Papers, MB 116 Box 7: Miscellaneous papers including Resistance Bookshop, MBL, Christchurch; Neil Rowe and Brent Wong, Little Big Mouth: The Story of the Little Girl Who Became Prime Minister, Wellington, 1968.

25 'Chris Wheeler, 'Starting Your Own Underground Printing Press', The First NZWEC, p.26.
} 
Tribunal (IPT) in 1974. Ferret's editor Marty Braithwaite was charged and convicted under the Police Offences Amendment Act 1967 in 1974.

Freedom of expression was a pressing issue for the bookshops. Richard Suggate noted that New Zealand was "much more restricted in terms of what was available in newspapers and magazines and certainly radical views... there was very little opportunity for giving them an airing". ${ }^{26}$ As producers, sellers and importers of alternative texts the Resistance Bookshops were familiar with the problems that government legislation posed. The Indecent Publications Act 1963 was one of the biggest hindrances for Resistance, as this legislation had the power to dictate whether a title could be sold by the bookshops. The Act had implications for both the material being produced within the shops and the material being imported into New Zealand by the bookshops. The IPT will be covered later in the chapter.

The Resistance Bookshops imported titles that were part of the increase in commercial alternative publishing that occurred from the 1960s. As suggested earlier, alternative publications were a non-mainstream source of information and ideas, covering unconventional topics and often presenting them in a new format. Alternative publishing became an important part of New Zealand print culture but before this is discussed, the broader context of international alternative and paperback publishing needs to be recognised as this had major implications for what was produced here. The 'paperback revolution' that had begun in the early 1950s changed the nature of bookselling worldwide. Paperbacks had first been produced in the 1930s and had been sold by the Left Book Club, Penguin and Allen Lane in Britain. However, it was not until the 1950s that paperback publishing became more widespread and for the book buyer this meant that titles became more affordable and accessible. These paperbacks helped to expand the market of book production, which had major effects for the wider publication and distribution of books. During the 1960s, a collection of small presses, bookshops and distributors from San Francisco fostered the rise of a new series of 'lifestyle'-type, do-it-yourself paperback publications. ${ }^{27}$ Bookshops in San Francisco like City Lights and Cody's and

\footnotetext{
${ }^{26}$ Suggate interview.

${ }^{27}$ Sam Binkley, 'The Seers of Menlo Park: The discourse of heroic consumption in the 'Whole Earth Catalog', Journal of Consumer Culture, November 2003, Vol. 3, No. 3, p.291.
} 
distributors and small presses like Book People and Shambhala were all part of this literary scene in the Bay area. These books had a countercultural target market and discussed things like organics, alternative technology, crafts and holistic lifestyle practices. ${ }^{28}$ These publications played a key role in changing the nature of the printing industry in the United States and many of the titles found their way to the Resistance Bookshops' stock list.

In New Zealand there was a similar boom in small alternative publishers, many of which focused on literary works. Presses like the Amphedesma Press and Cavemen Press published the work of poets like Hone Tuwhare and James K. Baxter and were distributed through the university bookshops and in some cases the Resistance Bookshops. ${ }^{29}$ The most high profile alternative publisher in New Zealand was Alister Taylor, who published a series of innovative non-fiction and literary titles including The Whole World Watches, an account of the anti-tour protests in Wellington in June 1970, The Brewers Bible in 1973 through to collections of poetry by Sam Hunt and James K. Baxter. ${ }^{30}$ Figure 28 shows a number of Taylor's book covers. These publications were created with a commercial motive and were well produced and printed professionally, unlike the publications being produced by underground publishers. But 'mainstream' booksellers were not always receptive to the types of publications that Taylor was producing. In a Listener article, Taylor commented that only 130 of the 500 booksellers approached to sell Bullshit and Jellybeans would stock it because of the title. ${ }^{31}$ Taylor was also subject to criticism and antagonised many within the 'movement' because he operated commercially, making money from the left. Whether or not this criticism was warranted is beside the point, what is important about Taylor's publications is that he enabled books to be published that otherwise may not have been.

\footnotetext{
28 ibid.

${ }^{29}$ For discussion of these small presses and others see Michael O'Leary, 'Alternative small press publishing in New Zealand: an introduction, with particular reference to the years 1969-1999', MA Thesis (English), Victoria University of Wellington, 2001.

${ }^{30}$ Lyn Brooke-White, Alister Taylor, and Chris Wheeler, The whole world watches: a record of Wellington protests against the All Black tour, Thursday, Friday, Saturday, June 11, 12, 13, 1970, Wellington, 1970; Sam Hunt, From Bottle Creek, Wellington, 1972; Malcolm Gramaphone, The Brewer's Bible, Wellington, 1973; James K. Baxter, James K. Baxter: 1926-1972, A Memorial Volume, Wellington, 1972.

${ }^{31}$ Bruce Wallace, 'The Exploits of Alister Taylor', New Zealand Listener, Vol.70, No.1711, p.11.
} 


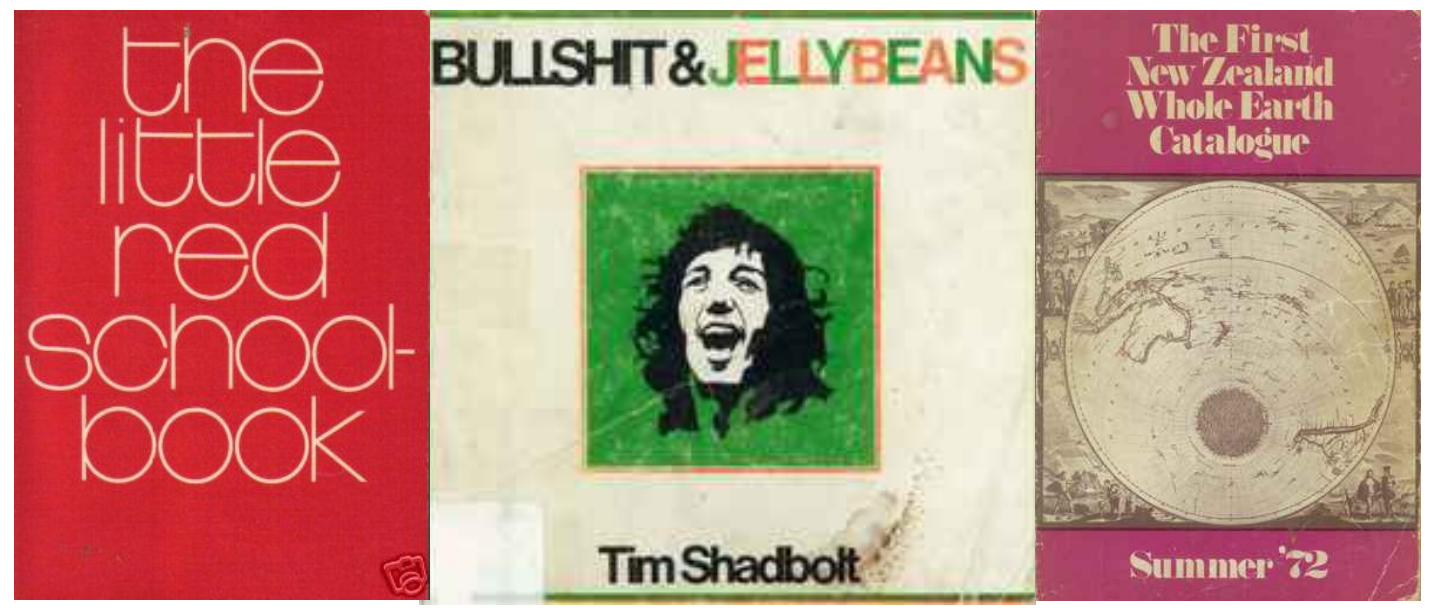

Figure 28 - A selection of Alister Taylor publications printed in the early 1970s.

A number of Alister Taylor's publications achieved very high sales figures, while other titles like The Little Red School Book generated much public attention due to its contentious content. Bullshit and Jellybeans, an informal history and memoir of the movement in New Zealand was very popular. It sold 12,000 copies in less than twelve months and continued to sell strongly due to Shadbolt's high profile status. ${ }^{32} 20,000$ copies of the First NZWEC were also sold, which showed that there was a market for locally produced alternative publications. Readers were interested in the ideas included in the NZWEC, which indicates that, at least at an abstract level, people were engaging with the radical ideas contained in the catalogue, they were pondering the notion of an 'alternative lifestyle' and print was an important avenue for people to do this. The success of Bullshit and Jellybeans also raises questions about why so many people bought this title. There are two factors which may have contributed to the book's success. Firstly, Shadbolt was a very high profile individual, he was essentially the public face of the youth and counterculture movements in New Zealand, travelling the country animatedly speaking to students and the media. Just as young politicised Americans read Yippie Abbie Hoffman's Steal This Book in the thousands, so too did politicised New Zealanders read Shadbolt's story and interpretation of events. ${ }^{33}$ Here was a young, radical student expressing his political views, alongside quotes from Che Guevara, photos from local demonstrations and political cartoons. Secondly, people could freely read about the 'movement' in the United States but the publication of Bullshit and Jellybeans was an opportunity for

\footnotetext{
32 ibid.

${ }^{33}$ Abbie Hoffman, Steal This Book, New York, 1971.
} 
New Zealanders to read about the 'movement' locally, it discussed subjects, politicians and campaigns which were active locally. People wanted to read about their own political circumstances and perhaps for young people in the early 1970s Bullshit and Jellybeans was a way to do this.

In New Zealand many of the titles that were sought after by radicalised people were not available in Whitcombe and Tombs or the London Bookshops, which were two of the major chain bookstores in New Zealand. Aside from this type of bookstore, there were also smaller independent booksellers in the main cities which attempted to cater for a less conventional readership. Independents like International/Liberation Books in Wellington sold left-wing texts, while stock at Unity Books, established in 1967, ranged from 'best sellers' through to less conventional titles like the Whole Earth Catalogue. ${ }^{34}$ Like the independent bookshops, university bookshops also sold a wide range of books and many sold the publications produced by political groups and underground publishers. However, these booksellers still did not stock the type of material that many of those that were associated with Resistance wanted access to. These individuals wanted to sell titles that had less of a commercial demand but were seen to be very important in terms of enabling people to have access to alternative sources of information. Additionally, the Resistance Bookshops represented something more than just being a political bookseller. They were spaces that existed to resist, challenge and support political activity, rather than to just distribute books.

The political material stocked by the three Resistance Bookshops was a core reason for the shops to operate, it was also essential for their sustainability. The political texts that were being circulated served an important purpose as the act of seeking out information and educating oneself was seen to be in itself a political act. The three Resistance Bookshops may have had regional differences but the particular type of leftist and countercultural material stocked was very similar between the three cities. This material, whether it was political, morally challenging, subversive or controversial, was intended to enable people to gain a better understanding of social issues. As outlined in chapter two, the bookshops carried a range of political titles, many of these came directly from communist publishers and Third World liberation

\footnotetext{
${ }^{34}$ Stewart Brand, Whole Earth Catalog, Baltimore, 1968; Rogers and Rogers, 1993, p.73.
} 
movements. The bookshops would subscribe to the distribution lists of the state publishing houses in the Soviet Union and China, the shops were then sent books, pamphlets and posters. In some cases publications would arrive unsolicited. At one point a collection of sayings by Kim Il Sung, the North Korean communist leader, was sent out to the bookshops, no such collection was ever requested, nor was it ever sold, resulting in it becoming a door stop for the Wellington shop. ${ }^{35}$ Auckland also tried to broaden the range of their stock by directly contacting groups associated with liberation movements in the Portuguese colonies - Mozambique, Guinea, Cape Verde and Angola and in Rhodesia (Zimbabwe). ${ }^{36}$

The rest of the stock came from a series of local and international wholesalers and distributors, who were individually approached by each bookshop and subsequently carried out orders on an individual basis. For instance, Richard Suggate would visit wholesalers around New Zealand, get radical and left wing books and then run accounts with these wholesalers. ${ }^{37}$ This was quite a trusting relationship, where Resistance would place an order, the books would arrive and then payment would follow. However, as has been shown the financial circumstances of Resistance did not always mean that the process was this simple. The limited weekly income was reliant largely on book sales, and rent and amenities were paid before wholesalers accounts. In the case of Alister Taylor Publications this led to strained relation between the publisher and the bookshops. Tony Currie commented that it was only after Auckland Resistance went out of business that the Christchurch bookshop experienced difficulties in obtaining stock. ${ }^{38}$ Publishers were concerned that Christchurch would also go out of business and be unable to pay their accounts, a situation that occurred when Auckland closed.

The Auckland shop manual identified the local wholesalers usually used by the Auckland shop to get international titles. Well known companies like Hicks Smith and Sons and Gordon and Gotch Ltd were used to acquire Penguin, Paladin and

\footnotetext{
${ }^{35}$ Suggate interview. Cock were also sent the same publication, a brief article about this was included in Cock, Issue 15, December 1971, Wellington, p.7.

${ }^{36}$ Auckland Resistance Bookshop Newsletter, November 1972, p.3, Jack Locke Papers: Resistance Bookshop, MB 116 Box 7, MBL, Christchurch.

${ }^{37}$ Suggate interview.

${ }^{38}$ Tony Currie, correspondence 4 February 2007.
} 
Panther paperback titles. ${ }^{39}$ These could be acquired cheaply and could be returned if they did not sell. Importing directly from international distributors was something that the Auckland shop did only occasionally and only if it was for books that local wholesalers did not stock. ${ }^{40}$ In contrast, Resistance in Wellington would often write away to international wholesalers to order both books and magazines. ${ }^{41}$ The major international distributor that Resistance had a relationship with was Book People, a San Francisco-based company set up in 1968 that distributed countercultural and alternative lifestyle paperbacks internationally. Book People stocked many of the 'doit-yourself' type books that were rapidly becoming popular due to the shift in interest towards alternative lifestyles. ${ }^{42}$ Despite the type of print that Book People distributed, they were still a major operation and in 1972 they distributed the books of 38 small American publishers to nearly 4000 retailers worldwide. ${ }^{43}$ Through Book People, Resistance was able to access a huge range of books that covered issues and topics that stimulated discussion and were relevant to the type of lifestyle based politics that many people using the shop were interested in. Ordering books from the United States often took up to three months to arrive so while each shop tended to order separately, some bulk orders were made. In one instance a triple order was made by Christchurch Resistance for copies of a book for itself, for the PYM in Auckland and for Co-op Books in Christchurch. ${ }^{44}$

The Resistance Bookshops were associated with local distributor Book Project, which imported left wing paperbacks and was located in Auckland. It was run by Joris de Bres, who was also involved with HART. It distributed titles from well-known international left wing publishers such as Pluto Press, Spokesman Books and New Left Books. ${ }^{45}$ Aside from stocking the Resistance Bookshops, Book Project was also set up like a book club, individuals could pay $\$ 10.00$ for a yearly subscription and receive a monthly newsletter and stock list, and they encouraged members to purchase

\footnotetext{
${ }^{39}$ ibid.; Bolster, p. 25.

${ }^{40}$ Bolster, pp.25-6.

${ }^{41}$ Suggate interview.

${ }^{42}$ One of their most in demand titles was the Whole Earth Catalog, which sold 100,000 copies in December 1970 alone. See Peter Collier, 'For Fun and Profit in San Francisco', New York Times, 13 February 1972, p.7.

43 ibid.

${ }^{44}$ Tony Currie to Wellington, c.1975, TFML, Box 1, Folder 3.

${ }^{45}$ Project Books Catalogue, February 1973, TFML, Box 3.
} 
books and pamphlets directly from them as they offered discounted prices. ${ }^{46}$ It was a small operation and for a time it was physically located in the same premises as Resistance in Auckland. ${ }^{47}$ The relationship between the two did not stop there as those involved with the shop even suggested at one point that Resistance could collectively take on the distribution rights for the left American presses in New Zealand as Book Project was seen to lack the "man/woman power" for the operation. ${ }^{48}$

Aside from these distinctly left-wing progressive publishers, Resistance also stocked the more 'mainstream' Penguin titles. Both Penguin's fiction and non-fiction titles were very popular and easy to obtain, which made them an attractive and logical choice for those with the responsibility of ordering stock for the bookshop. ${ }^{49}$ In reality, customers could get these titles from other booksellers but for the sake of generating an income, the texts were important because their popularity was guaranteed. Paperbacks were very important for Resistance, few hard-backed books were stocked because paperbacks were a lot cheaper and easier to sell. One of the few titles that was available in both hard and soft back in the Auckland Resistance Bookshop was Karl Marx by Werner Blumenberg, published by New Left Books. The illustrated biography, comprising 196 pages, was priced at $\$ 2.00$ for a paperback and $\$ 5.56$ a hardback in 1972; the substantial price difference explains why paperbacks were a more attractive option. ${ }^{50}$

As discussed in the preceding chapters, indecency legislation impacted on some of the print sold by the Resistance Bookshops. Generally, the stock that was distributed by Resistance was imported and sold without issue but there were some titles that were examined by the IPT, a judicial body established in 1963 that determined the suitability of texts for sale. The Tribunal considered texts that were externally submitted for assessment; this meant that the Tribunal itself could not decide to examine a particular publication, rather they had to be submitted by regulatory bodies like the Customs Department, and organisations like the Society for the Promotion of

\footnotetext{
${ }^{46}$ Auckland Resistance Newsletter, c. Christmas 1972, p.9, TFML, Box 1, Folder 1.

${ }^{47}$ Joris de Bres used a room in the Auckland Resistance's building as an office for an unspecified amount of time, Auckland Resistance Newsletter, c. Christmas 1972, p.9, TFML, Box 1, Folder 1.

${ }^{48}$ Auckland Resistance to Richard Suggate, c. February 1973, p.2, TFML, Box 1, Folder 1.

${ }^{49}$ Suggate interview.

${ }^{50}$ Listed in the 'Counter Culture' section, Resistance Catalogue, Auckland Resistance Bookshop, unnumbered, located in the TFML, Box 1, Folder 1.
} 
Community Standards (SPCS) or by individual members of the public. The Tribunal could classify a text indecent if it dealt with "sex, horror, crime, cruelty, or violence in a manner that was seen to be injurious to the public good". ${ }^{51}$ Out of a total of 938 decisions from 1964 till 1980 only 197 titles were declared not indecent, the remainder were either banned outright or had age restrictions imposed on them. ${ }^{52}$ Some of the titles that were sold by the bookshops, examined by the IPT and declared not indecent included Do It! in 1971 and the Little Red School Book in 1972. ${ }^{53}$ However, various issues of $O Z$, a countercultural magazine from London were declared indecent in $1973 .{ }^{54}$

The shops did not encounter problems with texts on leftist ideology or guerrilla warfare, and most countercultural texts were all brought in without difficulty; it was the texts that had sexual or drug related content that were subject to inspection by authorities. Quite often material that was being imported by Resistance was first examined by Customs then referred to the Tribunal. In one instance in 1972, 90 out of the 120 comics that had been imported by Resistance in Wellington were seized by Customs and referred to the IPT, or the 'dirty books tribunal' as it was often called. ${ }^{55}$ If an order was confiscated and then banned from sale, the bookshop would still be liable for the cost of importing the titles. This was problematic because the shops had enough trouble paying for book orders when the titles were actually sold, let alone those they did not get to sell. Christchurch was conscious of this situation and in a letter to Wellington wrote that "Customs only were interested in one book...Thank Christ we stopped the comics - they would have been seized". ${ }^{56}$ An interesting aspect of this letter was that Customs had delayed the decision to refer the book Blue Movie by Jerry Southern to the Tribunal; in the meantime the book had been on sale. This shows that Customs did not always confiscate texts when they came into the country;

\footnotetext{
${ }^{51}$ Indecent Publications Act 1963 quoted in Gordon Tait, The Bartlett Syndrome: Censorship in New Zealand, Christchurch, 1979, p.6.

52 Titles included books, magazines and films. The status of 'indecent' included those publications which were available for sale but had an age restriction. Statistic extracted from index of decisions of the IPT in Perry.

${ }^{53}$ Jerry Rubin, Do It: Scenarios of the Revolution, New York, 1970, declared not indecent, 5 August 1971; Soren Hansen, The Little Red Schoolbook, New Zealand edition, Wellington, 1972, declared not indecent, 6 April 1972. See Perry.

${ }^{54} \mathrm{OZ}$, London, various issues declared indecent 2 August 1973.

${ }^{55}$ Richard Suggate, 'More resistance - Or No Shop', Salient, Victoria University of Wellington, Vol.35, No.19, 3 August 1972, p.5.

${ }^{56}$ Terry Southern, Blue Movie, London, 1973; Tony Currie to Richard Suggate, 30 November 1973, TFML, Box 1, Folder 3.
} 
there were occurrences where Customs would consider a list of stock that had been imported and then make their referral, thus allowing the bookshop to sell the title in the meantime.

The most problematic type of publication for the Resistance Bookshops were the underground comics being imported from the United States. The American underground 'comix' represent a very particular period in the history of comics and graphic based narratives. This spelling distinguished these underground titles from comic books more generally, the ' $\mathrm{x}$ ' was said to emphasise the fact that they were $\mathrm{X}$ rated. ${ }^{57}$ These comics were not the mainstream Superman or Spiderman comics which had unleashed a kind of moral panic in New Zealand in the 1950 s. ${ }^{58}$ Rather the work of cartoonists like Robert Crumb was more connected to the Mad magazine style of illustration but far more explicit in their depiction of sex and violence. This style of comic book was intrinsically linked to the counterculture, which arose first out of San Francisco from 1967; comix captured the anti-Establishment sentiment through their discussion of taboo topics like drugs, religion, music and most predominantly, sex. ${ }^{59}$ Figure 29 shows a $X Y Z$ comics cover, one of the titles that was banned by the IPT in 1973.

While underground comics were humorous, satirical, challenging and offered a wideranging critique of society, they were seen by some to be gratuitous in their commentary and representations of society. In both the United States and New Zealand, the comics were subject to indecency claims and censorship. One of the major reasons that groups opposed the sale of these comics was because comics were traditionally perceived to be aimed at children and there was a fear that a child might pick up a copy of an X-rated comic and be exposed to explicit sex and drug use. In New Zealand, the 'anti-pornography' group, SPCS, lobbied the IPT to ban the sale of underground comics. In 1973 the Tribunal declared over 30 titles to be indecent and

\footnotetext{
${ }^{57}$ Roger Sabin, Comics, Comix \& Graphic Novels: A History of Comic Art, London, 1996, p.92.

${ }^{58}$ For discussion of the New Zealand response to the American comic books of the 1950s see Yska, 1993.

${ }^{59}$ Analysis of the American underground comics of this period include of Mark James Estren, $A$ History of Underground Comics, Third Edition, Berkley, 1993; Roger Sabin, Adult Comics: An Introduction, London and New York, 1993; Roger Sabin, Comics, Comix \& Graphic Novels: A History of Comic Art, London, 1996; Patrick Rozenkranz, Rebel Visions: The Underground Comix Revolution 1963-1975, Seattle, 2002.
} 
were therefore banned from sale. ${ }^{60}$ The distribution of these comics was endorsed by Resistance, notably by Richard Suggate, Wellington's shop manager. During the Tribunal's assessment process Suggate claimed that "many underground comics had a serious intellectual purpose...if we stifle comics we are hiding from the truths they reveal". ${ }^{61}$ Despite their controversial approach to exploring provocative topics, comics were a popular item for many of the bookshops' customers.

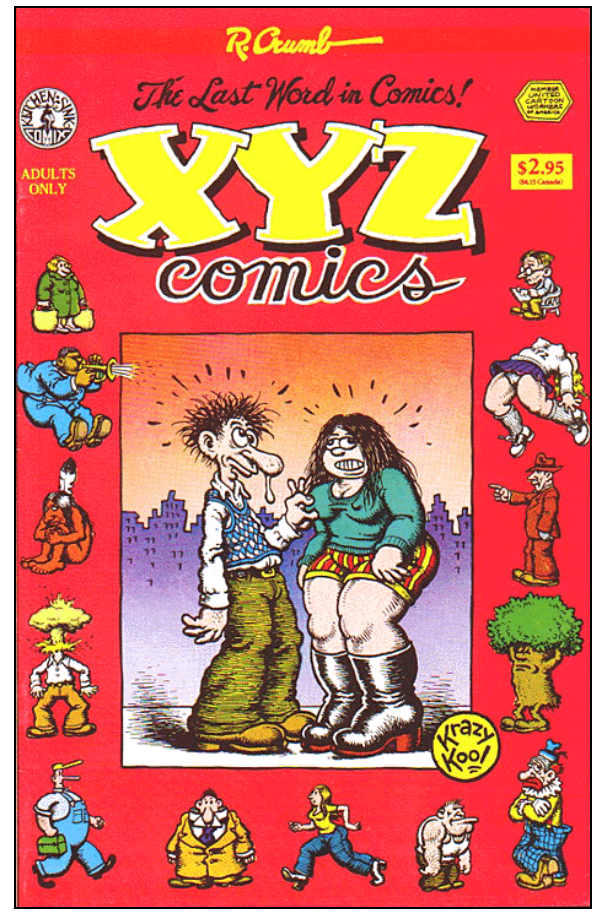

Figure 29 - Cover of XYZ Comics, banned in New Zealand in 1973. Robert Crumb, XYZ Comics, San Francisco, 1972.

Underground comics received a negative reaction, not just from anti-pornography groups but also within political circles, as feminist groups resented the underground comix focus on violent and exploitative sexual fantasies. ${ }^{62}$ Most often, the inclusion of women within an underground comic's narrative was purely as a sexual object and at times this narrative was based around sexual violence. The depiction of women in underground print was a contentious issue that was not confined to the publication of

\footnotetext{
${ }^{60}$ Decisions No.661-697 Various Comics (Delivered 15 June 1973, Gazetted 28 June 1973), listed in Perry.

61 “"Serious Purpose” In Comics From Underground', Source of article unknown, private collection of Richard Suggate.

${ }^{62}$ Beth Bailey, 'Sex as a Weapon: Underground Comix and the Paradox of Liberation', in Peter Braunstein and Michael Doyle (eds), Imagine Nation; The American Counterculture of the 1960s and 70 s, London and New York, 2002, p.313.
} 
underground comics. The use of the naked female body was seen frequently in some New Zealand underground publications. While most underground New Zealand newspapers and magazines did not have a high level of illustration like the American publications, Cock was an example that frequently included both illustrations and photographs of naked women. Cock was clearly aware of the appeal that the naked female body had on some readers and on one occasion even captioned a nude photo: "now that we've got your attention!". ${ }^{3}$ Figure 30 shows some of the naked images taken from Cock. The inclusion of such images could have been justified as a way to challenge mainstream attitudes about nudity and sexuality but to many women these images were gratuitous and did little more than objectify women as the mainstream press often did. The inclusion of the female body in these publications showed a lack of support for those women campaigning for equality and reinforced outdated and misogynous concepts about the role of women. The depiction of women in underground print was part of a much larger issue, which was the representation of women in all forms of popular print. Publications like the university capping books included photographs of naked women and the mainstream media was not excluded from this criticism. Aspects like the 'page 3 woman' which was included in some newspapers or the use of a provocatively dressed, or scantily clad women for advertising purposes were both condemned by feminist groups.

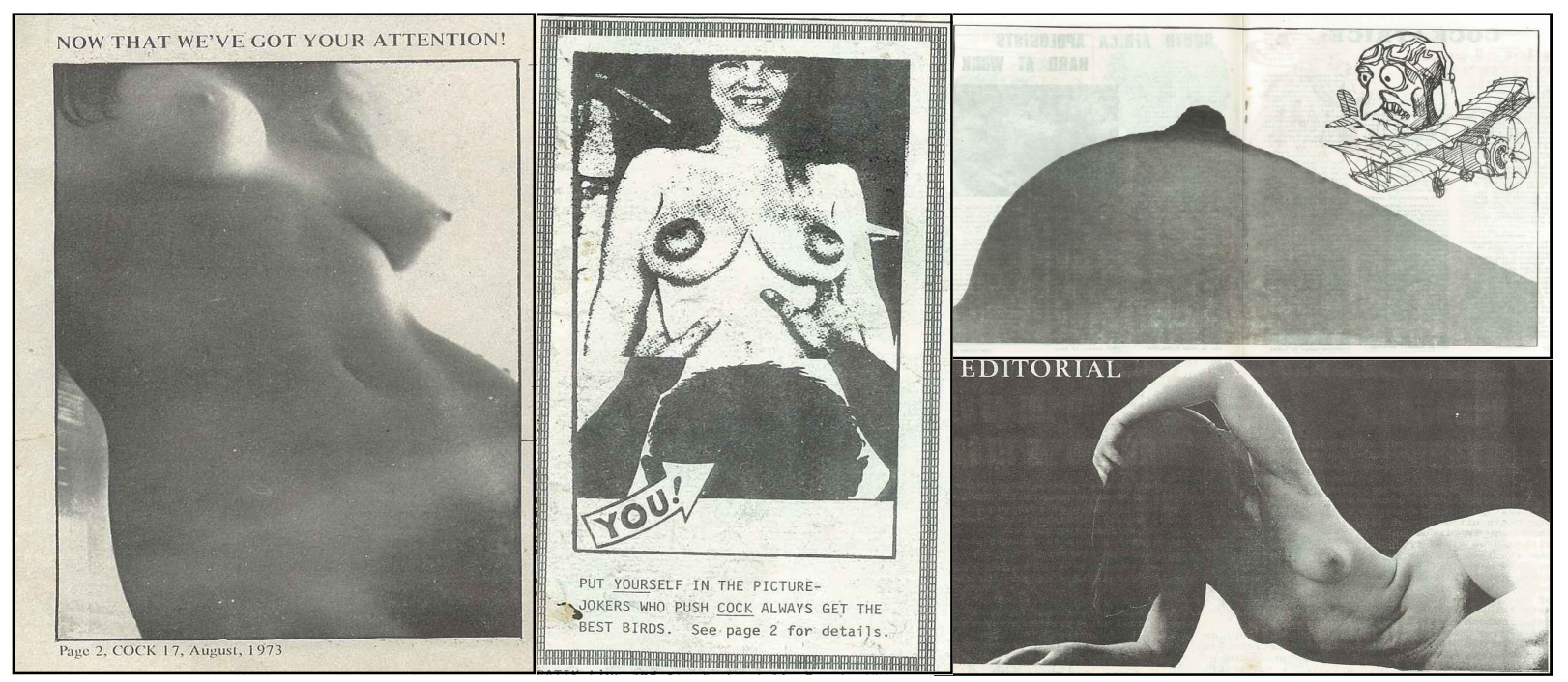

Figure 30 - Images of women from Cock magazine, No. 6, c.1968, p.3 and pp.17-18; No. 9, c.1969, p.32; No. 17, 1973, p.2.

${ }^{63}$ Cock, Issue 17, August 1973, p.2. 
During the early 1970s women's groups began to produce their own publications, which reflected their ideas, political beliefs and depicted women in a more multifaceted way. The first regular feminist newspaper in New Zealand, Broadsheet was established in July 1972. Broadsheet was highly engaged with the issue of female representation, with one of its earliest advertisements depicting a naked woman bound at the wrists with the caption "What does this all mean?" ${ }^{64}$ The newspaper was first produced by a team of women with little experience; it was a 12 page long newspaper, had a circulation of 200 and was distributed through subscription and at meetings. ${ }^{65}$ Broadsheet was by no means the only underground feminist publication produced in New Zealand. Throughout the country feminists from various positions produced their own newspapers and newsletters that outlined the issues and the state of the women's liberation movement in New Zealand. Throughout the 1970s publications including Circle produced monthly by Wellington group Sisters for Homophile Equality, $U p$ from under produced by the Wellington Women's Liberation Front and A Collective for Women produced by the Dunedin Collective for Woman, all produced their publications independently using community owned printing presses and distributing the material to women through various channels. With the exception of Broadsheet, stylistically these publications did not focus on the visual qualities of the publication as did some of the countercultural type print. As with other forms of grassroots political publishing, the core of these publications was content; print was the key means to express the politics, direction and debates occurring within the women's movement.

The women's movement was one of the few movements that established their own bookshops. While they were operating, Resistance encouraged feminist groups to use their space and also stocked feminist literature. However, in those years the amount of feminist literature available was still quite limited. Germaine Greer's The Female Eunuch had achieved very high sales, selling 8,000 copies in New Zealand in a mere eight weeks. ${ }^{66}$ But this title merely represented the beginning stage of a growing body of print which dealt with feminist topics. Publishers like Virago in the United Kingdom started in 1973 but it was not until the 1980s that more feminist texts were

\footnotetext{
${ }^{64}$ Pat Rosier, Broadsheet: Twenty Years of Broadsheet Magazine, Auckland, 1992, p.10.

65 ibid.

${ }^{66}$ Bruce Wallace, 'The Female Whirlwind', New Zealand Listener, Vol.69, 24 April 1972, pp.8-9.
} 
being produced. Women's bookshops were established, with Daybreak, opening in Dunedin in 1977, the Broadsheet bookshop in Auckland and the Women's Place bookshop in Wellington, opening in 1981 and the Kate Sheppard bookshop in Christchurch opening in 1982. ${ }^{67}$ The establishment of the women's bookshops were part of a wider move to establish spaces that were designated as women's spaces. To feminists the bookshops were important because "as well as spreading ideas, these bookshops acted as a physical centre of feminist activity, as they were highly visible, easy-to-access centres". ${ }^{68}$ The founding of the women's bookshops and the survival of other independents like Liberation Books and Unity Books both indicates that there remained a strong demand for radical and alternative literature and ensured that progressive texts would continue to be available, even though the Resistance Bookshops had closed.

All the print which has been examined in this chapter had a role in supporting the political momentum or 'radical space' which emerged from the late 1960s. Protesters and political groups regardless of their political affiliations used print to promote political causes, to encourage people to participate in campaigns and to create information channels that existed outside of 'mainstream' or conventional channels. The alternative and underground print being produced in New Zealand during the late 1960s, mid 1970s was able to achieve this. A print culture was formed that brought together information, ideas, graphics, language and design which was reflective of the of the protest culture that was thriving in New Zealand. This print whether a highly produced magazine like Earwig or a cheap, disposable leaflet handed out on the street, each was part of a wider attempt by political groups or individuals to use print as a means to promote political causes, to educate and to challenge social and political conventions on a scale not previously seen in New Zealand.

\footnotetext{
${ }^{67}$ Rosier, p.14; Rogers and Rogers, pp.83-4.

${ }^{68}$ Millar, p.134.
} 


\section{Conclusion}

The campaigning and wider climate of radical protest that emerged in New Zealand from the late 1960s was a blend of internationally influenced campaigns and nationally-focussed movements. Each campaign exhibited the raw indignation and idealism of the young political activists. The campaigns of international origin included the feminist movement, the anti-apartheid movement, opposition to the Vietnam War, the emergence of a Black Power movement and the expanding interest in exploring alternative lifestyles. When manifest in New Zealand, all these movements took distinctively local forms. This distinctiveness was exemplified in the government's ohu scheme which had links to ideas behind the alternative lifestyle movement and was also demonstrated by the Polynesian Panthers, who utilised the model and rhetoric of the American Black Panthers to empower Polynesians faced with institutionalised racism in New Zealand. These movements and campaigns were linked to international protest through the appropriation of rhetoric and 'freedom fighter'-type imagery. Radicals in New Zealand saw themselves very much part of an international struggle. The books, posters and magazines stocked by the Resistance Bookshops demonstrated this connection to the broader context of international protest and radical questioning. The 'movement' in New Zealand also included campaigns which were unique to this country. Peace campaigners and radical groups championed the anti-base cause, opposing foreign, particularly United States, military bases in New Zealand. Indigenous rights were also a very visible part of protest culture during the 1970s, with a new generation of Maori activists asserting their land and civil rights. New Zealanders opposed nuclear weapons by protesting against atmospheric testing in Pacific and the presence of nuclear ships in New Zealand waters and ports. These examples of protest and resistance that confronted distinctively local issues existed alongside those movements with international origins and created an expansive culture of protest and radicalism.

The protest that occurred between the late 1960s and early 1970s was shaped by the baby boomers, a generation born in the relatively affluent post-war years, who confronted social and political conventions on an unprecedented level. Within young radical circles, there was a belief that revolution could be achieved, that a new social 
order could be created. It was by questioning, challenging, protesting and cooperating with each other that a new society could be forged. Alongside the political issues that protesters were campaigning for was an international counterculture, a cultural phenomenon that was manifest in cultural expressions such as film, music, print, dress, appearance and 'lifestyle'. The counterculture was embraced in large numbers by young New Zealanders. It represented a culture far removed from the world of their parents and the 'Establishment'. For some the counterculture was apolitical but it was part of the broader scope of protest that flourished in New Zealand from the late 1960s to the early 1970 s.

The Resistance Bookshops were part of this broad cultural and political momentum. In this thesis, the culture of protest has been defined as a 'radical space' to represent the climate of increased protest while the bookshops have been described as 'radical spaces' in a more concrete sense, as they were physically spaces that were set up to oppose, challenge, resist and persuade. For the Resistance Bookshops, distributing texts was part of the political process. A central ethos behind the Resistance Bookshops was the belief that texts had the ability to mobilise for change and it was for this reason that the bookshops were able to cement themselves as an instrumental part of the 'movement'.

The 'movement' that Resistance Bookshops grew out of was relatively small, comprising a series of groups and individuals with diverse political beliefs and directions. Historically, street demonstrations were not a common occurrence in New Zealand. This period of political activity was very unique because some issues were able to get large numbers of New Zealanders from a range of backgrounds to mobilise. However, while thousands rallied against the Vietnam War and sporting contact with South Africa, this was not necessarily a regular activity for all those involved. These large-scale protests were just a part of a wider movement that was sustained by the efforts of a much smaller dedicated group. The smallness of the 'movement' both benefited and disadvantaged the Resistance Bookshops. The scale of the 'movement' meant that there were strong interconnections between groups and campaigns and particularly for Christchurch Resistance. This meant that their action centre was able to operate effectively, providing a space for groups in the city to meet, debate and organise. However, the small number of people that were involved with 
radical politics also had implications for the sustainability of the bookshops. There were limited customer numbers and this also impacted on the number of people committed to helping run the bookshops. The smallness of the 'movement' certainly affected the longevity of the bookshops but it was not solely responsible for the shops' closure, much of this can be attributed to the difficulties associated with sustaining political momentum.

From 1970 until around 1972 there was much enthusiasm for the Auckland Resistance Bookshop and its associated political actions. This made the bookshop a very dynamic 'radical space'. After this period the Auckland collective began to lose momentum, becoming isolated from the political activity in the city and the bookshop's support base gradually eroded. Sustaining political momentum is something that all political movements have to contend with. While individual political groups had the task of encouraging people to mobilise for single demonstrations, the bookshops had to generate ongoing support for a five day a week operation, where volunteers were expected to help out regularly. Standing behind a counter or sorting the week's food cooperative orders did not necessarily have the same appeal as direct street action. As shown in chapter two, each of the bookshops suffered from the changing levels of public support. This affected book sales, the range of activities that the shops could provide and limited the bookshops' association with the political activity going on in each of the cities. The Resistance Bookshops grew out of the political momentum of the early 1970s and as this culture of protest changed over the decade, the shops struggled to sustain their place within the increasingly fractured milieu of protest. It can be argued that the failure to sustain the political momentum around the bookshops was the fundamental reason that each bookshop closed, as this was the force that brought in supporters, income and ensured their relevance to the wider political community for whom they operated.

This thesis has looked at the Resistance Bookshops and the relationship that they had with the wider culture of protest from 1969-1977. The political campaigns active during this period were discussed in relation to the bookshops, revealing the interconnections between 'movement' activity and the operation of the shops. It was argued that the Resistance Bookshops were able to establish themselves as a core part of this culture of protest because they were a key source of political and alternative 
information. For political groups, education was seen as a step towards political awareness and action. By reading or attending teach-ins, people were exposed to new ideas and consequently were more likely to become involved in political activity. The Resistance Bookshops were an ideal space for this to occur. This study also examined the three bookshops in detail, looking at how they each operated as collectives, the type of material that was stocked, the facilities they offered and the difficulty that each shop faced in sustaining political momentum. An array of political, alternative and grassroots publications were stocked by the bookshops; the characteristics of this print, the content, methods of distribution and the inclusion of graphics were all explored to demonstrate how political groups used print to communicate, challenge and persuade.

When assessing the impact that the Resistance Bookshops made, it is difficult to argue that had the bookshops not been established that there would have been a more limited range of political and alternative information available in New Zealand. Certainly some of the books imported by Resistance were specialised but many of the same titles were also available at university bookshops and at the 'Old Left' bookshops. Had the bookshops not been opened it is likely that other avenues for distribution would have been found, just as they had existed prior to the establishment and after the closure of the shops. What is important about the Resistance Bookshops, which distinguishes them from any other bookseller or political organisation, is that they attempted to create a bridge between direct action and the literature that informed and in many cases shaped political campaigns, all while doing this within a radical framework of collective organisation. The impact of the bookshops also should not be determined by the relatively short lifespan of the shops. When looking specifically at the Auckland bookshop, the momentum around the shop may not have lasted year after year but this should not detract from the prominent status that the shop had during those first few thriving years. Instead it should be this period which is a marker of the effect that the shop had, as it shows how Resistance was able to successfully operate within the wider 'radical space' Auckland in the early 1970s.

The absence of the Resistance Bookshops within the historiography of radical activism in New Zealand during this period, demonstrates how historians have dealt with campaigns as single issue based rather than as being part of a multifaceted 
culture of protest. The history of the Resistance Bookshops has shown that there were links between individuals, groups and campaigns involved within the 'movement'. This reveals that each 'single issue' movement did not operate in isolation; specific groups may have had a separate and distinct agenda but the individuals involved ensured that there was a cross over and relationship between movements. The history of the bookshops also illustrates that there were more dimensions to the 'radical space' of the 1970s than just protest groups and street demonstrations. Activists were exploring other avenues of resistance, whether though publishing their own magazines or by helping to run food cooperatives. There were other methods which challenged the 'Establishment' just as effectively. One thing that the bookshops highlight however, is how easy it is to wrongly characterise the 1970s as a period of tumultuous radicalism. The documentary sources and oral accounts of those involved with the bookshops give a sense of how vibrant and dynamic the political activity was but it needs to be remembered that the group associated with the shops and radical groups like the PYM was very small. Even the biggest anti-Vietnam War protests, which drew in a wide spectrum of supporters, only comprised a very small portion of the population, most of whom would not have been proponents of the widespread social and political change that was promoted by the more radical activists.

In this thesis, the Resistance Bookshops have been an important frame for examining the relationship between print and politics. The mere fact that these young activists chose to establish bookshops is evidence of the value that was placed on print and reading as political tools. There was power in ideas and by providing an avenue for people to access this information, the bookshops were playing a part in helping to create a political consciousness. A central question to this study was the impact that texts could have on a reader. One cannot conclude that texts were the major stimulus for people to mobilise for the anti-Vietnam war movement. Certainly newspaper articles and the photographs of the dead and injured Vietnamese made a strong impression on New Zealanders but the graphic footage of the war on television and the deployment of New Zealand troops was probably the major stimulus for the majority of people to protest. But for movements like the feminist movement, texts were an important component in getting many women thinking about women's rights. They were a crucial part of the dissemination of feminist ideas and this, combined 
with personal experience can perhaps be the two contributing factors behind getting women mobilised in the women's liberation movement.

This study has highlighted the central role that print had within political movements during this period. It helped to inform and educate, it was a means of communication and particularly for 'grassroots' publishing, it was a medium in which people could retain control over content and circulation. Print produced at a localised level was an important part of the information circulated through the Resistance Bookshops. There was a great deal of ephemeral type of publication printed on the bookshops' own premises. These leaflets and newsletters were not just a tool for spreading radical ideas, rather the actual act of self publishing was in itself a form of radical activity. The publications that were being churned out of the shops' printing presses were dissident in content but also the means that such material was being distributed was outside of mainstream channels, providing a genuine alternative source of information for activists. These pamphlets, leaflets and newspapers played an important part in raising political awareness, particularly as print was one of the most accessible ways for radical ideas to circulate. The large amount of print that was consistently being produced by political groups does suggest that there was a conviction that awareness could lead to action. This confidence that political groups had in the power of print does suggest that Resistance's print productions actually did made an impact on getting people to attend meetings, to join street protests and to give their support to collective ventures like the Resistance Bookshops.

Finally, one of the important things that the history of the Resistance Bookshops emphasises is how differently political activity was formed and carried out in the 1960s and 1970s than it is in the early Twenty-First Century. Due to the freeing up of information generally and huge advances in communication technology, the speed and access to information that people now have has changed how political activity is shaped. For the Resistance Bookshops communication was largely carried out by post. Each shop had a telephone but long-distance phone calls were still expensive, hence the reliance on the postal service. This meant that there was a much slower process for communicating between shops and with book wholesalers. Information about demonstrations was communicated through word-of-mouth, at meetings or through flyers posted around town. To compare this with the present day, the 
importance of the internet and electronic forms of communication as tools for activists cannot be overstated. Print is still a core medium but political groups now have their own websites, discussion boards and they can instantly communicate and gain access to information on political campaigns going on anywhere around the world. The importance of the internet as a crucial tool for spreading information and for creating networks between individuals, groups, and campaigns was confirmed with the antiglobalisation demonstrations which first surfaced in Seattle in November 1999. This was the first political movement to be born from the internet and demonstrated how the internet could be used to get people to mobilise for political actions. But while access to information has increased and communication can be much quicker, protest movements still face similar problems to movements in the 1970s. Encouraging people to mobilise, getting balanced coverage within the mainstream press, and sustaining a political momentum are all factors that continue to be relevant. One can only presume that print and organising bases like the Resistance Bookshops will continue to play a role in addressing these issues and others within the ever changing scope of radical politics. 


\section{Bibliography}

\section{Primary Sources}

\section{Contemporary Publications}

Andrews, George and Vinkenoog, Simon (eds), The Book of Grass: An Anthology of Indian Hemp, New York, 1967

Baxter, James K., James K. Baxter: 1926-1972, A Memorial Volume, Wellington, 1972

Brand, Stewart, Whole Earth Catalog, Baltimore, 1968

Brooke-White, Lyn, Taylor, Alister and Wheeler, Chris, The Whole World Watches: A Record of Wellington Protests Against the All Black Tour, Thursday, Friday,

Saturday, June 11, 12, 13, 1970, Wellington, 1970

Cannabis Cultivators' Guide, Wellington, 1970

Carson, Rachel, Silent Spring, London, 1962

Friedan, Betty, The Feminine Mystique, New York, 1963

Gramaphone, Malcolm, The Brewer's Bible, Wellington, 1973

Greer, Germaine, The Female Eunuch, London, 1970

Hansen, Soren, The Little Red Schoolbook, New Zealand Edition, Wellington, 1972

Hoffman, Abbie, Steal This Book, New York, 1971

Hopkins, Jerry (ed), The Hippie Papers: Notes from the Underground Press, New York, 1968

Hunt, Sam, From Bottle Creek, Wellington, 1972

Nabokov, Vladimir, Lolita, Paris, 1955

Rowe, Neil and Wong, Brent, Little Big Mouth: The Story Of The Little Girl Who Became Prime Minister, Wellington, 1968

Rubin, Jerry, Do It!: Scenarios of the Revolution, New York, 1970

Shadbolt, Tim, Bullshit and Jellybeans, Wellington, 1971

Southern, Terry, Blue Movie, London, 1973

Taylor, Alister and Barr, Jim, The Muldoon Annual Jokebook, Wellington 1971 
The 2nd New Zealand Whole Earth Catalogue, edited by Dennis List and Alister Taylor, Martinborough, 1975

The First New Zealand Whole Earth Catalogue Summer' 72, edited by Owen Wilkes, Jim Chapple, Dennis List, Tim Shadbolt, Alan Admore and John Pettigrew, Wellington, 1972

Wolfe, Tom, The Electric Kool-Aid Acid Test, New York, 1968

\section{Newspapers and Magazines}

8 o'clock Auckland Star, Auckland

Assistance, Christchurch Resistance Bookshop and Action Centre Newsletter

Beechleaves, Native Forest Action Council, Wellington

Broadsheet, Broadsheet Collective, Auckland

Canta, University of Canterbury, Christchurch

Circle, Sisters for Homophile Equality, Wellington

Cock, Wellington

Counter-Culture Free Press, Dunedin

Craccum, University of Auckland, Auckland

Critic, University of Otago, Dunedin

Earwig, Auckland

Ferret, Christchurch

Foreign Control Watchdog, Campaign Against Foreign Military Activities in New Zealand, Christchurch

Gay Liberator, Gay Liberation Front, Auckland

HART News, Halt All Racist Tours, Christchurch

Itch, Wellington

MOOHR Newsletter, Maori Organisation on Human Rights, Wellington

New York Times, New York

New Zealand Environment, Chippenham Community, Christchurch 
New Zealand Listener, Wellington

New Zealand Spartacist, New Zealand Spartacist League, Wellington

New Zealand Tribune, Socialist Unity Party, Auckland

New Zealand Truth, Wellington

Nose, Wellington Resistance Bookshop Newsletter

OZ, London

People's Union: Community Information Service, Auckland

PYM Rabble, Wellington Progressive Youth Movement

PYM Rebel, Auckland Progressive Youth Movement

Rag-Tag, Rabble-Rousing, Mickey Mouse Stuff, Christchurch Progressive Youth Movement

Repeal, Organisation to Halt Military Service, Christchurch

Roadrunner, Wellington and Taranaki Drivers Union, Wellington

Salient, Victoria University of Wellington

Socialist Action, Socialist Action League, Wellington

The Southern Flyer, Dunedin

Up From Under, Wellington Women's Liberation Front, Wellington

Papers, Ephemera, and Archives

Background papers relating to production of 'The Paper', 1973-1975, David Wickham papers, 95-222-2/2, Alexander Turnbull Library, Wellington

Bookseller Newsletters, Eph-A- BOOKSELLERS-Q-T, Alexander Turnbull Library, Wellington

Christchurch Joint Council of Vietnam: contains both minutes and protest literature, MB 83 1966-1971, Macmillan Brown Library, University of Canterbury,

Christchurch

Gramaphone, Malcolm: Papers relating to 'Counter Culture' and 'Resistance' 19651973, Misc-MS-0293, Hocken Library, Dunedin

Jack Locke Papers: Miscellaneous papers including Resistance Bookshop, MB 116 Box 7, Macmillan Brown Library, University of Canterbury, Christchurch 
Newsletter and meeting notes from Resistance Wellington, Eph-B-BOOKSELLERResistance Wellington, Alexander Turnbull Library, Wellington

Organisation to Halt Military Service, MSS 068, JC Beaglehole Room, Victoria University of Wellington

Pamphlets, fliers and ephemeral material collected by H. O. Roth of approximately A4 size 1960-80s, Eph-B-Roth, Alexander Turnbull Library, Wellington

- Eph-B-ROTH-Resistance

- Eph-B-ROTH-Resistance-1974-01

- Eph-B-ROTH-Protests at Albert park 1969-74

- Eph-B-ROTH-PYM Auckland

- Eph-B-ROTH-PYM Wellington and Christchurch

- Eph-B-ROTH-Progressive

Papers re Progressive Youth Movement 1970 [1991], Keith Stewart collection:

Ephemera relating to protest and student movements, MS-Papers-6142-1, Alexander Turnbull Library, Wellington

Posters advertising bookshops and booksellers, mainly in the Wellington, 1962-, EphC-BOOKSELLERS, Alexander Turnbull Library, Wellington

Progressive Youth Movement [Ephemera relating to the PYM 1967-1991], Eph-APROGRESSIVE/PYM, Alexander Turnbull Library, Wellington

Progressive Youth Movement [Ephemera relating to the PYM 1967-1991], Eph-BPYM, Alexander Turnbull Library, Wellington

Progressive Youth Movement, 1968, David Wickham papers, 95-222-1/10, Alexander Turnbull Library, Wellington

Republican Movement: Papers 1966-1974, Misc-1974, Hocken Library, Dunedin

Resistance Papers, Christchurch 1963-1987, Deposited by David Young, Central 316 Reference ANZC Archives, Christchurch City Library, Christchurch

Tom Fanthorpe Memorial Library, Wellington Resistance Bookshop's Library Material, 1960-80s, to be deposited in the Hocken Library, Dunedin in 2008

Interviews and Correspondence - Private collection of Megan Simpson

Sue Bradford, interviewed 27 September 2006

Marty Braithwaite, interviewed 20 August 2006

Tony Currie, correspondence 8 August 2006 and 4 February 2007

Murray Horton, interviewed 20 August 2006 
Bill Rosenberg, interviewed 19 August 2006

Richard Suggate, interviewed 2 June 2006 and 20 August 2006

\section{Secondary Sources}

\section{Books}

A Willis Street Bookseller Celebrating 20 Years, Wellington, 1987

Ali, Tariq and Watkins, Susan, 1968: Marching in the Street, New York, 1998

Anae, Melani (ed), Polynesian Panthers, Auckland, 2006

Anderson, Terry H., 'The New American Revolution: the Movement and Business', in David Farber (ed), The Sixties: From Memory to History, Chapel Hill and London, 1994

Anderson, Terry H., The Sixties, Second Edition, New York, 2004

Armstrong, David, A Trumpet to Arms: Alternative Media in America, Los Angeles, 1981

Atton, Chris, Alternative Media, London, 2002

Bailey, Beth, 'Sex as a Weapon: Underground Comix and the Paradox of Liberation', in Peter Braunstein and Michael Doyle (eds), Imagine Nation; The American

Counterculture of the 1960s and 70s, London and New York, 2002

Barrowman, Rachel, A Popular Vision: the Arts and the Left in New Zealand, 19301950, Wellington, 1991

Beeby, Clarence Edward, Books You Couldn't Buy: Censorship in New Zealand, Wellington, 1981

Belich, James, Paradise Reforged: A History of the New Zealanders from the 1880s to the year 2000, Auckland, 2001

Berger, Dan, Outlaws of America: The Weather Underground and the Politics of Solidarity, Oakland, 2006

Bloom, Alexander (ed), Long Time Gone: Sixties America Then and Now, New York, 2001

Boraman, Toby, 'The New Left in New Zealand', in Pat Maloney and Kerry Taylor (eds), On The Left: Essays on Socialism in New Zealand, Dunedin, 2002

Boraman, Toby, Rabble Rousers and Merry Pranksters: A History of Anarchism in Aotearoa/New Zealand from the mid 1950s to the early 1980s, Christchurch, 2007 
Braunstein, Peter and Doyle, Michael (eds), Imagine Nation; The American Counterculture of the 1960s and 70s, London and New York, 2002

Brenes, Wini, “'Of This Generation”: The New Left and the Student Movement' in Alexander Bloom (ed), Long Time Gone: Sixties America Then and Now, New York, 2001

Brunton, Alan, Edmond, Murray, Leggott, Michele, Big Smoke: New Zealand Poems 1960-1975, Auckland, 2000

Brunton, Alan, Years Ago Today: Language and Performance: 1969, Wellington, 1997

Butterworth, Susan, More Than Law and Order: Policing a Changing Society 194592, Dunedin, 2005

Cavallo, Guglielmo and Chartier, Roger, A History of Reading in the West, Amherst, 1999

Chartier, Roger, On The Edge Of The Cliff: History, Language and Practices, Baltimore and London, 1997

Cleveland, Les, The Politics of Utopia: New Zealand and its Government, Wellington, 1979

Dann, Christine, Up From Under: Women and Liberation in New Zealand, 19701985, Wellington, 1985

Darnton, Robert, The Forbidden Best-Seller of Pre-Revolutionary France, New York, 1995

Darnton, Robert, The Great Cat Massacre: And Other Episodes in French Cultural History, New York, 1984

Dix, John, Stranded in Paradise: New Zealand Rock and Roll, 1955 to the Modern Era, Second Edition, Auckland, 2005

Doyle, Michael William, 'Staging the Revolution: Guerrilla Theater as a Countercultural Practice: 1965-68', in Peter Braunstein and Michael Doyle (eds), Imagine Nation: The American Counterculture of the 1960s and 70s, London and New York, 2002

Duncombe, Stephen, Notes from the Underground: Zines and the Politics of Alternative Culture, London and New York, 1997

Ellwood, Robert S., Islands of the Dawn: The Story of Alternative Spirituality in New Zealand, Honolulu, 1993

Elworthy, Sam, Ritual Song of Defiance: A Social History of Students at the University of Otago, Dunedin, 1990 
Estren, Mark James, A History of Underground Comics, Third Edition, Berkley, 1993

Farber, David (ed), The Sixties: From Memory to History, Chapel Hill and London, 1994

Farge, Arlette, Subversive Words: Public Opinion in Eighteenth-century France, Cambridge, 1994

Fink, Carole, Gassert, Philipp, and Junker, Detlef (eds), 1968: The World Transformed, Cambridge and New York, 1998

Franks, Peter, Print and Politics: A History of Trade Unions in the New Zealand Printing Industry, 1865-1995, Wellington, 2001

Gitlin, Todd, The Sixties: Years of Hope, Days of Rage, Toronto, 1987

Glamuzina, Julie, Out Front: Lesbian Political Activity in Aotearoa 1960-1985, Hamilton, 1993

Glessing, Robert J., The Underground Press in America, Bloomington, 1970

Green, Anna and Hutching, Megan, Remembering: Writing Oral History, Auckland, 2004

Griffith, Penny, Harvey, Ross and Maslen, Keith (eds), Book and Print in New Zealand: A Guide to Print Culture in Aotearoa, Wellington, 1997

Guy, Laurie, Worlds in Collision: The Gay Debate in New Zealand 1960-1980, Wellington, 2002

Haas, Anthony, A Study in Protest: The Wellington Committee on Vietnam, May 1, 1965-March 6, 1967, Wellington, 1967

Hamilton, Stephen, A Radical Tradition: A History of the Victoria University of Wellington Students' Association, 1899-1999, Wellington, 2002

Harris, Aroha, Hikoi: Forty Years of Maori Protest, Wellington, 2004

Hercock, Fay, A Democratic Minority: A Centennial History of the Auckland University Students' Association, Auckland, 1994

Horrocks, Dylan (ed), Nga Pakiwaituhi o Aotearoa: New Zealand Comics, Revised Edition, Auckland, 2000

Jones, Tim, A Hard-Won Freedom: Alternative Communities in New Zealand, Auckland, 1975

Judt, Tony, Postwar: A History of Europe Since 1945, London, 2005 
Laity, Paul (ed), Left Book Club Anthology, London, 2001

Leame, Laurence, The Paper Revolutionaries: The Rise of the Underground Press, New York, 1972

Lewis, Roger, Outlaws of America - The Underground Press and its Context: Notes on a Cultural Revolution, London, 1972

Locke, Elsie, Peace People: A History of Peace Activities in New Zealand, Christchurch, 1992

Martin, John E. and Taylor, Kerry (eds), Culture and the Labour Movement, Palmerston North, 1991

McKenzie, Donald F., Bibliography and the Sociology of Texts, Cambridge, 1999

Moloney, Pat and Taylor, Kerry (eds), On The Left: Essays on Socialism in New Zealand, Dunedin, 2002

Ostertag, Bob, People's Movements: The Journalism of Social Justice Movements, Boston, 2006

Parker, Michael, The SIS, Palmerston North, 1979

Parkin, Jane (ed), Unity Books 30 Years, Wellington, 1997

Peck, Abe, Uncovering the Sixties: The Life and Times of the Underground Press, New York, 1991

Perry, Stuart, Indecent Publications: Control in New Zealand, Wellington, 1980

Poata-Smith, Evan S. Te Ahu, 'He Pokeke Uenuku I Tu Ai: The Evolution of Contemporary Maori protest', in Paul Spoonley, Cluny Macpherson, David Pearson (eds), Nga Patai: Racism and Ethnic Relations in Aotearoa/New Zealand, Palmerston North, 1996

Rabel, Roberto G., New Zealand and the Vietnam War: Politics and Diplomacy, Auckland, 2005

Richards, Trevor, Dancing On Our Bones: New Zealand, South Africa, Rugby and Racism, Wellington, 1999

Rogers, Anna and Rogers, Max, Turning the Pages: The Story of Bookselling in New Zealand, Auckland, 1993

Rose, Jonathon, The Intellectual Life of the British Working Class, New Haven and London, 2001

Rosier, Pat, Broadsheet: Twenty Years of Broadsheet Magazine, Auckland, 1992 
Rozenkranz, Patrick, Rebel Visions: The Underground Comix Revolution 1963-1975, Seattle, 2002

Sabin, Roger, Adult Comics: An Introduction, London and New York, 1993

Sabin, Roger, Comics, Comix \& Graphic Novels: A History of Comic Art, London, 1996

Sargent, Lyman Tower and Sargisson, Lucy, Living in Utopia: New Zealand's Intentional Communities, Aldershot, 2004

Sharf, Jean, Players, Protestors and Politicians: A History of the University of Canterbury Students' Association, Christchurch, 1995

Stephens, Julie, Anti-Disciplinary Protest: Sixties Radicalism and Postmodernism, Cambridge, 1998

Streitmatter, Rodger, Voices of Revolution: The Dissident Press in America, New York, 2001

Tait, Gordon, The Bartlett Syndrome: Censorship in New Zealand, Christchurch, 1979

Templeton, Malcolm, Human Rights and Sporting Contacts: New Zealand Attitudes to Race Relations in South Africa, 1921-94, Auckland, 1998

Templeton, Malcolm, Standing Upright Here: New Zealand in the Nuclear Age 19451990, Wellington, 2006

Thorns, David and Sedgwick, Charles, Understanding Aotearoa/New Zealand: Historical Statistics, Palmerston North, 1997

Tindall, Rik, Generations in Dissent: A Century of Protest from University of Canterbury Students, 1894-1994, Christchurch, 1994

Walker, Ranginui, Ka Whawhai Tonu Matou Struggle Without End, Second Edition, Auckland, 2004

Watson, Chris and Shuker, Roy, In The Public Good? Censorship in New Zealand, Palmerston North, 1998

Wilkes, Owen, Protest: Demonstrations Against The American Military Presence In New Zealand: Omega 1968, Woodbourne 1970, Mount John 1972,

Harewood/Weedons 1973, Wellington, 1973

Wilson, Roger, From Manapouri to Aramoana: The Battle for New Zealand's Environment, Auckland, 1982

Young, David, Our Islands, Our Selves: A History of Conservation in New Zealand, Dunedin, 2004 
Yska, Redmer, All Shook Up: The Flash Bodgie and the Rise of the New Zealand Teenager in the Fifties, Auckland, 1993

Yska, Redmer, New Zealand Green: The Story of Marijuana in New Zealand, Auckland, 1990

\section{Articles}

Bollinger, Tim, ‘Comic Story', New Zealand Listener, 5 August 1995, pp.42-43

Cowan, Steven, 'The Politics of the Street', New Zealand Monthly Review, No. 331, August and September 1994, pp.34-6

Horton, Murray, 'Radicals in Retrospect', New Zealand Monthly Review, No. 331, August and September 1994, pp.30-3

Hunt, Andrew, 'When Did The Sixties Happen? Searching for New Directions', Journal of Social History, Fall 1999, Vol. 33, No. 1, pp. 147-62

Binkley, Sam, 'The Seers of Menlo Park: The discourse of heroic consumption in the 'Whole Earth Catalog', Journal of Consumer Culture, November 2003, Vol. 3, No. 3, pp.283-313

Rabel, Roberto G. and Cook, Megan, 'Women and the Anti-Vietnam War Movement in New Zealand, Oral History in New Zealand, Vol. 10, 1998, pp.1-5

Rabel, Roberto G., 'The Vietnam Antiwar Movement in New Zealand', Peace \& Change, January 1992, Vol. 17, No.1, pp.3-33

\section{Theses and Research Essays}

Bell, Peter Brook, 'The protest movement in Dunedin against the Vietnam War, 19651973', BA (Hons) Research Essay in History, University of Otago, 1989

Boraman, Toby, 'The New Left and anarchism in New Zealand from 1956 to the early 1980s: an anarchist communist interpretation', PhD Thesis (Political Science), University of Otago, 2006

Jackman, Paul, 'The Auckland Opposition to New Zealand's Involvement in the Vietnam War 1965-1972: An Example of the Achievements and Limitations of ideology', MA Thesis (History), University of Auckland, 1979

Meyrick, Michael, 'Police and Protest: the Role of the New Zealand Police as Controllers of Public Order During the Period 1966-73', MA Thesis (History), University of Auckland, 1984

Millar, Grace, 'Because we are all women': the relationship between ideas of women's liberation and the development of the New Zealand feminist movement', MA Thesis (History), Victoria University of Wellington, 2003 
O'Leary, Michael, 'Alternative small press publishing in New Zealand: an introduction, with particular reference to the years 1969-1999', MA Thesis (English), Victoria University of Wellington, 2001

Rainbow, Stephen, 'The Unrealised Potential of Green Politics: A study of four green parties', Victoria University of Wellington, PhD Thesis (Political Science), 1991

Simpson, Megan, 'Escaping the Isolated Suburbia Trip: Exploring the alternative lifestyle movement in New Zealand in the 1970s', BA (Hons) Research Essay in History, Victoria University of Wellington, 2005

\section{Films}

Campbell, Russell, Rebels in Retrospect: The Political Memoirs of Some Members of Christchurch and Wellington PYM: in 19 parts, 74 Minutes, Vanguard Films, Wellington, 1991

Green, Sam and Siegel, Bill, The Weather Underground, 92 Minutes, Free History Project, New York, 2004

Ivens, Joris, Spanish Earth, Terre d'espagne, 1937

\section{Websites}

Brunton, Alan, Interviewed with Chris Bourke, September 2000, New Zealand Electronic Poetry Centre, University of Auckland; available from http://www.nzepc.auckland.ac.nz/authors/brunton/brief/bourke.asp; accessed 13 February 2007

Chan, Stephen, 'Political Radicalism and Radical Literature: Usurpation and Incorporation in the New Zealand Literary World from 1969', Silver Jubilee Triennial Conference of the Association for Commonwealth Literature and Language Studies, University of Kent, August 1989, New Zealand Electronic Poetry Centre, University of Auckland; available from http://www.nzepc.auckland.ac.nz/misc/chan.asp; accessed on 29 January 2007

Lincoln Cushing, 'A brief history of the "clenched fist" image', Docs Populi: Documents for the Public, available from http://www.docspopuli.org/articles/Fist.html; accessed 24 March 2006

OZ, London, 1967-1973, The OZ Library; all issues are available electronically at http://www.oztrading.net/library.htm; accessed throughout 2006/07

Percy, John, 'Youth in Revolt: the 60s and today', Green Left Weekly, No.329, 19 August 1998; available at http://www.greenleft.org.au/1998/329/20586; accessed 2 December 2006 